Illinois State University

ISU ReD: Research and eData

Theses and Dissertations

$10-9-2019$

\title{
Syntheses, Characterization, and Preliminary Evaluation of Potential Ruthenium Anticancer Complexes Containing Schiff Base Ligands
}

Stephen Mensah

Illinois State University

Follow this and additional works at: https://ir.library.illinoisstate.edu/etd

Part of the Inorganic Chemistry Commons

\section{Recommended Citation}

Mensah, Stephen, "Syntheses, Characterization, and Preliminary Evaluation of Potential Ruthenium Anticancer Complexes Containing Schiff Base Ligands" (2019). Theses and Dissertations. 1164.

https://ir.library.illinoisstate.edu/etd/1164

This Thesis is brought to you for free and open access by ISU ReD: Research and eData. It has been accepted for inclusion in Theses and Dissertations by an authorized administrator of ISU ReD: Research and eData. For more information, please contact ISUReD@ilstu.edu. 


\section{SYNTHESES, CHARACTERIZATION, AND PRELIMINARY EVALUATION \\ OF POTENTIAL RUTHENIUM ANTICANCER COMPLEXES \\ CONTAINING SCHIFF BASE LIGANDS}

\section{STEPHEN MENSAH}

90 Pages

Platinum-based drugs have over the years been administered in the treatment of tumours. Unfortunately, platinum resistance and the severe side effects associated with the treatments has necessitated the research for new anti-cancer drugs. Ruthenium(II) and Ruthenium(III) complexes have shown promise as useful alternative anticancer agents. The lead candidates include the $\mathrm{Ru}(\mathrm{II})$ complex RAPTA-C, a ruthenium(II)-arene complex $\left[\mathrm{Ru}\left(\eta^{6}-p\right.\right.$-cymene $) \mathrm{Cl}_{2}(1,3,5$-triaza-7phosphaadamantane)] and the $\mathrm{Ru}(\mathrm{III})$ complex NAMI-A [imidazoleH][trans-Ru(imidazole) (dimethyl sulfoxide) $\mathrm{Cl}_{4}$ ]. Both compounds have shown potent cytotoxic activity in several primary human tumor models. Unfortunately, NAMI-A could not advance in clinical evaluations due to limited efficacy in vivo, while the clinical evaluation of RAPTA-C is unknown. Therefore, there is a need for novel cancer therapeutics that have high biological activity, are relatively easy to synthesize, and can readily be modified. This work focuses on the use of 2-acetylpyridine and 2pyridinecarboxaldehyde for the synthesis, characterization, and preliminary evaluation of derivatives of both the RAPTA-C and NAMI-A anticancer complexes containing Schiff base ligands. Here, the results of the synthesis of these compounds and their subsequent characterization using ${ }^{1} \mathrm{H}$ NMR, MS, fluorescence and UV-Vis spectroscopies are presented.

KEYWORDS: Cancer; Schiff bases; RAPTA-C; RM175; Human serum albumin 
SYNTHESES, CHARACTERIZATION, AND PRELIMINARY EVALUATION

OF POTENTIAL RUTHENIUM ANTICANCER COMPLEXES

CONTAINING SCHIFF BASE LIGANDS

STEPHEN MENSAH

A Thesis Submitted in Partial

Fulfillment of the Requirements

for the Degree of

MASTER OF SCIENCE

Department of Chemistry

ILLINOIS STATE UNIVERSITY

2019 
Copyright 2019 Stephen Mensah 
SYNTHESES, CHARACTERIZATION, AND PRELIMINARY EVALUATION

OF POTENTIAL RUTHENIUM ANTICANCER COMPLEXES

CONTAINING SCHIFF BASE LIGANDS

STEPHEN MENSAH

COMMITTEE MEMBERS:

Michael Ian Webb, Chair

Eirin Sullivan

Shawn Hitchcock 


\section{ACKNOWLEDGMENTS}

Many people have, in diverse ways, contributed significantly towards my success in obtaining my master's degree in Chemistry. Firstly, I would like to thank Dr. Michael Webb for being my advisor and offering me all the needed guidance and support through this process. I am also very grateful to all the professors and faculty in the Department of Chemistry at Illinois State University for their immense contribution towards my success in this program. Again, I also appreciate the contributions of Dr. Shawn Hitchcock and Dr. Eirin Sullivan who were both on my Thesis Committee. I also further express my sincere gratitude to all my professors who in diverse ways offered expert guidance through my graduate coursework to enable me to complete the master's program.

I also thank my mother, Margaret Berekoh, and my brother Mr. John Anthony Turkson for their Support throughout my study. Each day in ISU was never completed without the unflinching support and motivation of my lovely wife, Bridget Frimpomaah Fobi. My sincere appreciation goes to her for her kind words every time throughout my study.

And finally, to all my friends and members of the Webb lab for their support and encouragement, I say thank you.

S. M. 


\section{CONTENTS}

Page

ACKNOWLEDGMENTS

TABLES

FIGURES

CHAPTER I: INTRODUCTION 1

$\begin{array}{ll}\text { Introduction to Cancer } & 1\end{array}$

$\begin{array}{ll}\text { Platinum-based Anticancer Drugs } & 1\end{array}$

$\begin{array}{ll}\text { Ruthenium Anticancer Compounds } & 6\end{array}$

Ruthenium(II) Arene Anticancer Compounds $\quad 9$

$\begin{array}{ll}\text { Thesis Research } & 14\end{array}$

CHAPTER II: SYNTHESES AND CHARACTERIZATION OF SIX

$\begin{array}{ll}\text { SCHIFF BASE LIGANDS } & 17\end{array}$

$\begin{array}{ll}\text { Introduction } & 17\end{array}$

$\begin{array}{ll}\text { Experimental } & 21\end{array}$

$\begin{array}{ll}\text { General materials and methods } & 21\end{array}$

$\begin{array}{ll}\text { Instrumentation } & 21\end{array}$

N-[(Pyridin-2-yl)ethylidene]aniline (L1) 21

N-[(Pyridin-2-yl)methylidene]aniline (L2) 22

4-Nitrophenylferrocene $\quad 22$

4-Ferrocenylaniline $\quad 23$

N-\{[(Pyridin-2-yl)ethylidene $]$ imino $\}$ phenylferrocene (L3) 23

(2-\{[(Pyridinyl)methylidene $]$ imino $\}$ phenyl)ferrocene (L4) 24 
$\begin{array}{ll}\text { Ferrocenoyl azide } & 24\end{array}$

2-(Trimethylsilyl)ethyl ferrocenylcarbamate 25

$\begin{array}{ll}\text { Aminoferrocene } & 25\end{array}$

2-\{[(Pyridinyl)ethylidene]iminoferrocene (L5) 26

N-[(Pyridin-2-yl)methylidene]iminoferrocene (L6) 26

$\begin{array}{ll}\text { General UV-vis Experimental Conditions } & 27\end{array}$

$\begin{array}{ll}\text { Results and Discussion } & 27\end{array}$

$\begin{array}{ll}\text { Conclusion } & 44\end{array}$

CHAPTER III: SYNTHESES OF RUTHENIUM(II) ARENE COMPLEXES

CONTAINING SCHIFF BASE LIGANDS 45

Ruthenium(II) Arene Schiff Base (RAS) Complexes 45

$\begin{array}{ll}\text { Experimental } & 46\end{array}$

$\begin{array}{ll}\text { General Materials and Methods } & 46\end{array}$

$\begin{array}{ll}\text { Instrumentation } & 46\end{array}$

$\begin{array}{ll}\text { Synthesis of Ru(II) starting material } & 47\end{array}$

$\begin{array}{ll}\text { Synthesis of Compound } \mathrm{C}_{1} & 47\end{array}$

$\begin{array}{ll}\text { Synthesis of Compound } \mathrm{C}_{2} & 48\end{array}$

$\begin{array}{ll}\text { Synthesis of Compound } \mathrm{C}_{3} & 48\end{array}$

$\begin{array}{ll}\text { Synthesis of Compound } \mathrm{C}_{4} & 49\end{array}$

Synthesis of Compound $\mathrm{C}_{5}$

Synthesis of Compound $\mathrm{C}_{6} \quad 49$

$\begin{array}{lr}\text { General UV-vis Spectra Conditions } & 50\end{array}$

$\begin{array}{lr}\text { Results and Discussion } & 50\end{array}$ 
CHAPTER IV: PRELIMINARY STUDIES ON THE INTERACTION

BETWEEN THE RUTHENIUM(II) ARENE COMPLEXES

AND HUMAN SERUM ALBUMEN

Introduction

Experimental

General Materials and Methods

Instrumentation

General Fluorescence Experimental Conditions

Results and Discussion

Conclusion

REFERENCES

APPENDIX A: SUPPLEMENTARY DATA OF CHAPTER TWO 


\section{TABLES}

Table

Page

1. The six Schiff base ligands and the reagents that were

combined to make them

2. Stern-Volmer quenching constant, $\mathrm{K}_{\mathrm{sv}}$, Binding Constants, $\mathrm{K}_{\mathrm{b}}$ and number of binding sites $\mathrm{n}$ determined at $37{ }^{\circ} \mathrm{C}$ and $\mathrm{pH} 7.4$ 


\section{FIGURES}

Figure

1. Simplified mechanism of action of cisplatin 2

2. The different generations of platinum anticancer compound 3

3. Structures of Platinum compounds most commonly used in Asia 4

4. Rate of aqueous ligand exchange of various metal cations 6

5. Mechanism of Action of RAPTA-C anticancer compounds $\quad 8$

6. The general structure of $\mathrm{Ru}(\mathrm{II})$ arene complexes, (a)contains one bidentate ligand or (b) one monodentate ligand and one bidentate ligand, where $\mathrm{A}$ is an arene ring, and $\mathrm{X}, \mathrm{Y}$ and $\mathrm{Z}$ are ligands $\quad 9$

7. RAPTA-C and RM175 compounds 11

8. The structure of the Ru(II) complex TLD1433 14

9. Synthetic routes of the target Schiff base ligands 15

10. Generic structure of proposed $\mathrm{Ru}(\mathrm{II})$ compounds 16

11. The general reaction scheme for Schiff base syntheses where, $\mathrm{R}_{1}, \mathrm{R}_{2}$, and $\mathrm{R}_{3}$ are any organic chain

12. Fluoroquinolone, an anticancer Schiff base compound 18

13. Organoruthenium-based paullone anticancer complexes 18

14. Structures of the target Schiff base ligands 20

15. Reaction scheme for Schiff base L1 27

16. The ${ }^{1} \mathrm{H}$ NMR Spectrum of Schiff base L1 in $\mathrm{CDCl}_{3}$

17. Reaction scheme for Schiff base L2 29

18. The ${ }^{1} \mathrm{H}$ NMR spectrum of $\mathrm{L} 2$ in $\mathrm{CDCl}_{3}$ 
19. Reaction scheme for the synthesis of 4-nitrophenylferrocene

20. Reaction scheme for the synthesis of 4-ferrocenylaniline

21. Synthetic scheme of L3

22. The ${ }^{1} \mathrm{H}$ NMR spectrum of $\mathrm{L} 3$ in $\mathrm{CDCl}_{3}$

23. Synthetic scheme of L4

24. The ${ }^{1} \mathrm{H}$ NMR spectrum of $\mathrm{L} 4$ in $\mathrm{CDCl}_{3}$

25. Synthetic scheme of ferrocenoyl azide from ferrocenecarboxylic acid

26. Synthetic scheme to prepare 2-(trimethylsilyl)ethylferrocenylcarbamate from

ferrocenoyl azide

27. Synthetic scheme to prepare aminoferrocene from

2-(trimethylsilyl)ethylferrocenylcarbamate

28. Synthetic scheme to prepare L5

29. The ${ }^{1} \mathrm{H}$ NMR spectrum of Schiff base L5 in $\mathrm{CDCl}_{3}$

30. Synthetic scheme of L6

31. The ${ }^{1} \mathrm{H}$ NMR spectrum of L6

32. UV-vis spectrum of L1 in 50\% DMSO and PBS(aq) at pH of 7.4 and a temperature of $37^{\circ} \mathrm{C}$

33. UV-vis spectrum of $\mathrm{L} 2$ in $50 \%$ DMSO and $\mathrm{PBS}(\mathrm{aq})$ at $\mathrm{pH}$ of 7.4 and a temperature of $37^{\circ} \mathrm{C}$

34. UV-vis spectrum of L4 in 50\% DMSO and PBS (aq) at pH of 7.4 and a temperature of $37^{\circ} \mathrm{C}$

35. Examples of ruthenium(II) Schiff base complexes

36. Ruthenium(II) arene Schiff base target compounds 
37. Reaction scheme for the synthesis of $\mathrm{Ru}(\mathrm{II})$ arene dimer starting material

38. The ${ }^{1} \mathrm{H}$ NMR spectrum of the $\mathrm{Ru}(\mathrm{II})$ arene dimer in $\mathrm{D}_{2} \mathrm{O}$

39. General reaction scheme for the $\mathrm{Ru}(\mathrm{II})$ arene Schiff base compounds

40. The ${ }^{1} \mathrm{H}$ NMR spectrum of complex $\mathrm{C}_{1}$ in $\mathrm{CDCl}_{3}$

41. The ${ }^{1} \mathrm{H}$ NMR spectrum of $\mathrm{C}_{2}$ in $\mathrm{CDCl}_{3}$

42. The ${ }^{1} \mathrm{H}$ NMR spectrum of complex $\mathrm{C}_{4}$ in $\mathrm{CDCl}_{3}$

43. The ${ }^{1} \mathrm{H}$ NMR spectrum of complex $\mathrm{C}_{6}$ in $\mathrm{CDCl}_{3}$

44. UV-vis spectrum of $100 \mu \mathrm{M}$ solution of $\mathrm{C}_{1}$ in $10 \%$ DMSO and PBS (aq) at a pH of 7.4 and a temperature of $37^{\circ} \mathrm{C}$

45. Crystal structure of HSA showing the domain-binding sites (Sudlow I and Sudlow II)

46. Fluorescence spectra of HSA $(2.5 \mu \mathrm{M})$ in the presence of increasing concentration of $\mathbf{C}_{2}$ from $0 \mu \mathrm{M}$ up to $25 \mu \mathrm{M}$ at $37^{\circ} \mathrm{C}$ and $\mathrm{pH}$ of 7.4

47. Stern-Volmer plot for $\mathrm{C}_{2}$

48. Modified Stern-Volmer plot for $\mathrm{C}_{2}$ 


\section{CHAPTER I: INTRODUCTION}

\section{Introduction to Cancer}

According to the World Health Organization (WHO), cancer is a group of diseases characterized by the uncontrolled growth of abnormal cells with the tendency to spread to other parts of the body. ${ }^{1}$ Cancer development and metastasis, the spread of cancer cells, occurs in several stages and often may arise from the dysfunction of several regulatory features that ensures proper functioning of the cells. ${ }^{2}$ Cancer is one of the leading causes of death globally,,$^{1,3}$ accounting for $13 \%$ of all deaths worldwide. It is estimated that about 9.6 million deaths would be recorded in 2018 while the number of new cases for 2018 was approximately 14.1 million. ${ }^{1}$ Despite the over $\$ 1.16$ trillion annual economic cost for the treatment of cancer, ${ }^{1}$ there is no current therapeutic method that can provide a complete treatment of most forms of proliferated tumors in humans. ${ }^{3}$ This necessitates the development of novel chemotherapeutic agents for the treatment of cancer.

\section{Platinum-based Anticancer Drugs}

Since the discovery of the bioactivity of cis-diamminedichloroplatinum(II), commonly known as cisplatin in 1965 by Dr. Rosenberg et al. ${ }^{4,5}$ and its subsequent approval by the U.S Food and Drugs Administration (FDA) in $1978,{ }^{6}$ metallochemotherapeutics, especially platinumbased compounds have been successfully used for treatment of many neoplastic conditions. Cisplatin is the most common antineoplastic chemotherapeutic agent used to treat several types of cancer, including ovarian, cervical, stomach, bladder, head, and neck. ${ }^{5}$ The use of cisplatin as a chemotherapeutic agent greatly improved the survival chances for many cancer patients. For example, the drug increased the rate of cure of testicular cancer from less than $10 \%$ to $90 \%$ in modern oncotherapy ${ }^{6}$ and almost $100 \%$ when the cancer cells are in stage 1 of development ${ }^{5}$ where the cancer has attacked tissues next to the testicle, but not lymph nodes, or more distant 
cells in the body. ${ }^{9}$ In North America and Europe, it is estimated that more than one million cancer patients are on cisplatin treatments. ${ }^{6}$

Cisplatin treats cancer cells mainly by cross-linking deoxyribonucleic acid (DNA) and inhibiting transcription and replication. ${ }^{6}$ The drug first enters the cell by the copper transporter, CTR $1^{4,7}$ and undergoes ligand exchange by exchanging one or both chloride ligand with molecules of water (Figure 1). ${ }^{6}$

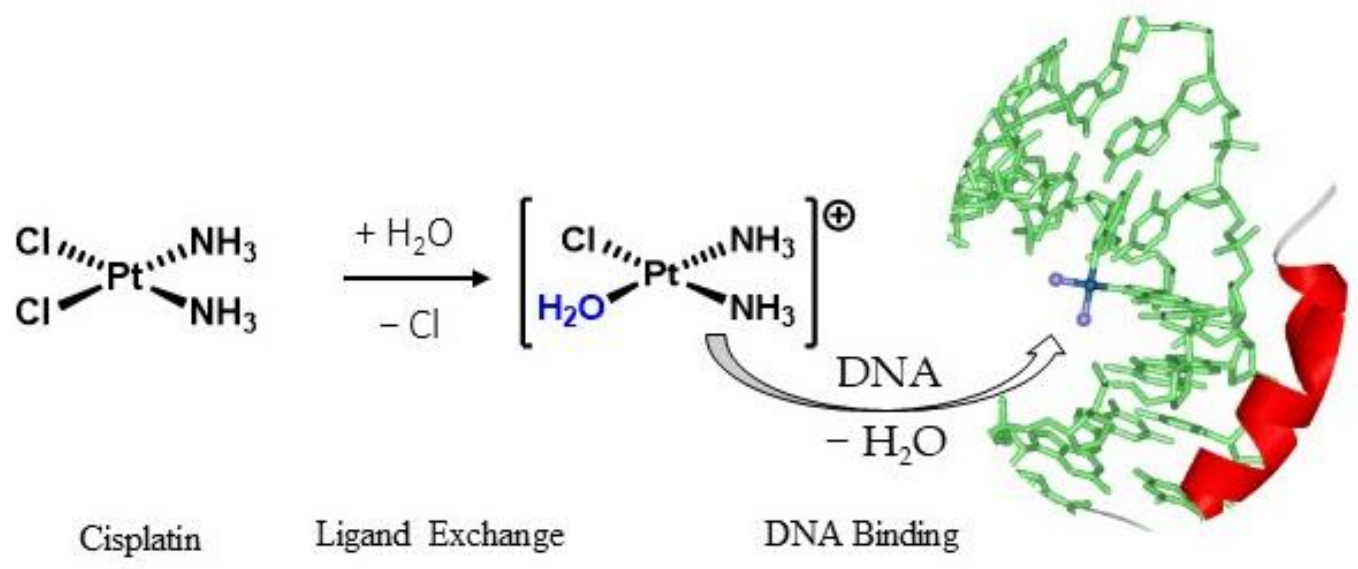

Figure 1. Simplified mechanism of action of cisplatin. Adapted with permission ${ }^{13}$

The resulting platinum(II) aqua complexes formed are strong electrophiles that are highly reactive towards several biological ligands. The N7 position of the purine base guanine is strongly nucleophilic in nature. Hence, cisplatin readily binds to DNA at that position and may yield bifunctional adducts with loss of both chloride ligands or water. The main product formed from cisplatin-DNA interaction is the intrastrand 1,2-d(GpG) cross-link as shown in Figure 1. This mode of action of cisplatin triggers apoptosis. ${ }^{6}$

Unfortunately, the use of cisplatin to treat tumors is associated with high toxicity and severe side effects due to nonselective binding to DNA. ${ }^{5}$ These severe side effects include nephrotoxicity, neurotoxicity, ototoxicity or toxicity to the ear, nausea, vomiting and in some 
cases permanent hearing loss and acute renal failure. ${ }^{4,5}$ It is estimated that only $1 \%$ of intravenously administered cisplatin enters the cell nucleus. It has been reported that about $60 \%$ of cisplatin administered reacts with glutathione $(\mathrm{GSH})$ to form the product $\left[\mathrm{Pt}(\mathrm{GS})_{2}\right]{ }^{4}$ This product, however does not contribute to the inactivation of the drug, rather, the GSH-cisplatin adduct inhibits the selenoenzyme thioredoxin reductase (TrxR) and induces redox reactions within the cell. This behavior has been associated with nephrotoxicity and hepatic dysfunction. Therefore, the off-target toxicity of cisplatin is partly attributed to redox agitations within the cell. ${ }^{4}$ This mechanism of action of cisplatin however induces platinum resistance. ${ }^{6}$

To overcome the difficulties associated with cisplatin, the ligands around the metal have been modified to produce Carboplatin and Oxaliplatin which are second and third generation compounds of Pt used to treat tumors (Figure 2). ${ }^{4,10}$ These modifications of the ligands around the platinum affect the adducts the complex forms with biological tissues. Carboplatin was approved by the FDA in 1989 and Oxaliplatin was approved in 2002. Carboplatin is used for the treatment of ovarian cancers whereas Oxaliplatin is used to treat colon and rectal cancers. ${ }^{4}$ Carboplatin and oxaliplatin are both considered to exhibit mechanisms of action identical to that of cisplatin, related to attack on DNA. Carboplatin possesses a relatively stable chelating 1cyclobutanedicarboxylato (CBDCA) ligand as its leaving group. ${ }^{6}$

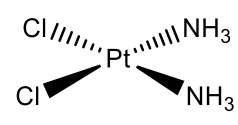

Cisplatin (First generation)

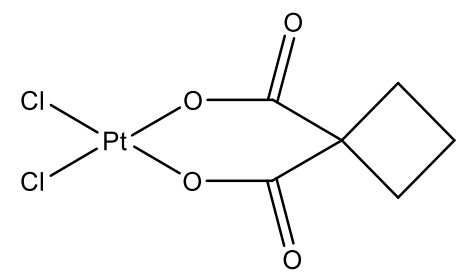

Carboplatin

(Second generation)

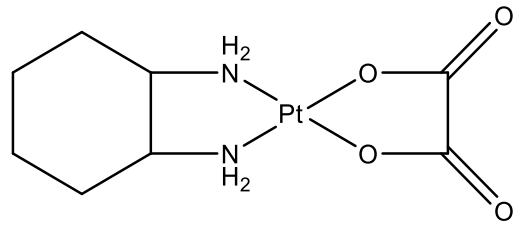

Oxaliplatin (Third generation)

Figure 2. The different generations of platinum anticancer compounds. 
Carboplatin however, gives reduced side effects compared to cisplatin ${ }^{6,11}$ which is attributed to a change in reactivity at the metal center due to the chelating nature of the leaving group ligand and, the potential conformation that this ligand assumes. ${ }^{11}$ Oxaliplatin, on the other hand, also features a chelating oxalate leaving group ligand together with a chelating $R, R$ diaminocyclohexane (DACH) nonleaving group ligand. ${ }^{11}$ This drug shows improved performance over cisplatin toward colorectal cancers. ${ }^{6,11}$ The exceptional activity of Oxaliplatin in the treatment of colon and rectal cancers is attributed to the ability of the drug to act as a substrate for organic cation transporters (OCTs), which are overexpressed in a large number of colon cancer patients. ${ }^{11}$ However, cisplatin remains a chemotherapeutic agent of choice with widespread use. ${ }^{5}$ Three other platinum compounds shown in Figure 3, nedaplatin, heptaplatin and lobaplatin, are widely employed in Asia. ${ }^{4}$
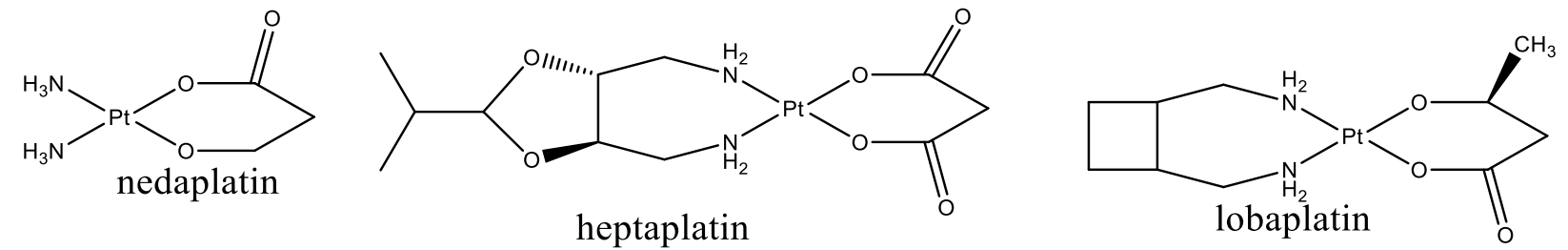

Figure 3. Structures of Platinum compounds most commonly used in Asia.

Nedaplatin finds clinical use in China whilst heptaplatin and lobaplatin are used in South Korea and Japan respectively. ${ }^{5}$ Nedaplatin was discovered and developed in Japan, which since 1995 ,together with China are the only countries where the drug has attained clinical approval. ${ }^{11}$ Like cisplatin and carboplatin, this drug has cis-ammine nonleaving group ligands. The chelating leaving group ligand is glycolate, which enhances water solubility to $10 \mathrm{mg} \mathrm{mL}^{-1}$ compared to cisplatin which has a solubility of $2.5 \mathrm{mg} \mathrm{mL}-1 .{ }^{11}$ Though clinical exploration of the drug is still 
on-going, the drug is commonly used to treat cancer of the head and neck and esophagus as well as small cell lung cancer and non -small cell lung cancer. ${ }^{11}$

Heptaplatin was developed in Korea by the Sunkyong Industry Research Center and entered clinical trials in the 1990s. The drug was subsequently approved for clinical use by the Korean Food and Drug Administration in 1999. The compound has a malonate chelating leaving group ligand and a chelating 2-(1-methylethyl)-1,3-dioxolane-4,5-dimethanamine nonleaving group. The nonleaving group ligand assumes a seven-membered chelate ring conformation giving the generic name of the drug. Heptaplatin is commonly used for the treatment of gastric cancer. ${ }^{11}$

Lastly, lobaplatin was first developed by ASTA Medica in Germany while clinical evaluations of the drug were initially carried out in Europe, the United States, Australia, Brazil, and South Africa all examined its efficacy in patients of varying cancers. Clinical approval for medical treatments was only obtained in China in $2010 .{ }^{11}$ Lobaplatin is considered a derivative of heptaplatin with a cyclobutane ring fused to the seven-membered chelate ring compared to the functionalized dioxolane in heptaplatin. The drug is used most commonly for the medical treatment of chronic myelogenous leukemia but is also administered in patients with small cell lung cancer and metastatic breast cancer. ${ }^{11}$

Complexes of metals such as $\mathrm{Pt}(\mathrm{II}), \mathrm{Pt}(\mathrm{IV})$, and $\mathrm{Ru}(\mathrm{II})$, exhibit slow ligand kinetics which is comparable to many cellular division processes (Figure 4). The ligand exchange mechanism of these metals depends on the metals and the ligands bonded to them. Square planar compounds of $\mathrm{Pt}(\mathrm{II})$ undergo a ligand exchange by an associative process where the incoming ligand coordinates as fifth ligand after which one of the original ligands dissociates. However, octahedral $\mathrm{Ru}(\mathrm{II})$ complexes initially lose a ligand to form a five-coordinate intermediate after which the other ligand bonds to the compound. ${ }^{10}$ 


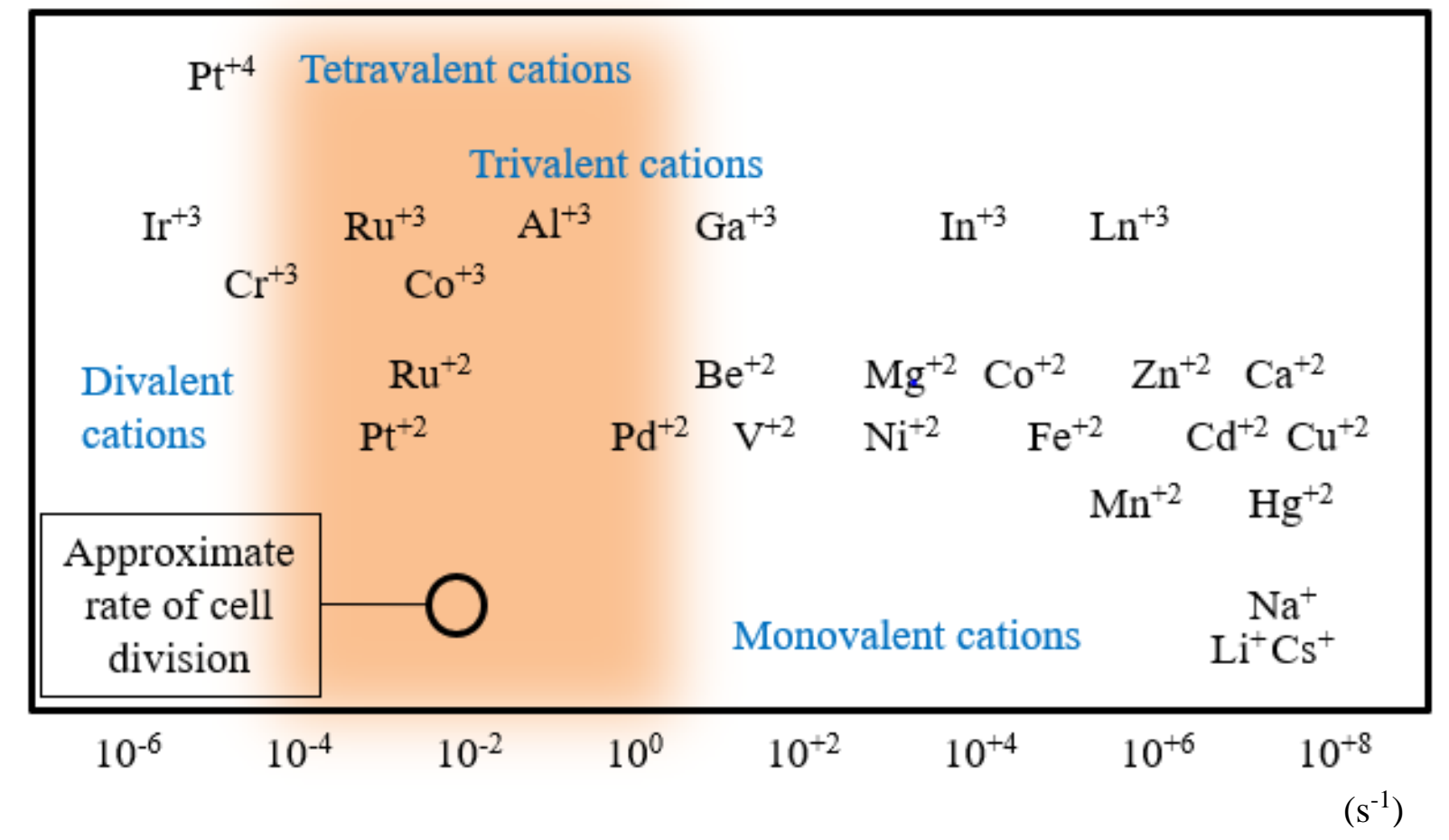

Figure 4. Rate of aqueous ligand exchange of various metal cations.

Adapted with permission ${ }^{9}$

\section{Ruthenium Anticancer Compounds}

To overcome the limitation of platinum-based chemotherapeutics, ruthenium compounds have been investigated for the development as anticancer drugs. ${ }^{3} \mathrm{Ru}(\mathrm{II})$ compounds exhibit ligand exchange kinetics similar to Pt(II) complexes. ${ }^{17}$ These complexes exhibit ligand exchange kinetics in water at a rate comparable to the kinetics of cellular reproduction (mitosis). ${ }^{18}$ It is therefore suggested that $\mathrm{Ru}$ ions could remain inside the cell throughout the entire cell lifespan. ${ }^{12}$ Initially, the ruthenium complex undergoes aquation where a chloride ligand is exchanged for water forming hydrolyzed products. This suggests a selective activation mechanism for Ruchlorido complexes. In $\mathrm{Ru}$ arene complexes, the rate of hydrolysis is also influenced by the nature of the leaving group, the arene group and the chelating ligand. ${ }^{12}$ 
The higher concentration of glutathione and lower concentration of molecular oxygen in tumor cells renders them more acidic than normal healthy cell. ${ }^{12,14}$ This means that Ru complexes can be taken up as $\mathrm{Ru}(\mathrm{III})$ where they can be activated by reduction to the active $\mathrm{Ru}(\mathrm{II})$ oxidation states within cancer cells. This, in one proposed reason, explains why the $\mathrm{Ru}$ complexes are less toxic compared to Pt complexes. ${ }^{12,14}$

The ammine complexes, fac- $\left[\mathrm{RuCl}_{3}\left(\mathrm{NH}_{3}\right)_{3}\right]$ and cis- $\left[\mathrm{Ru}\left(\mathrm{NH}_{3}\right)_{4} \mathrm{Cl}_{2}\right]$ have long been found to be active against cancer cells. ${ }^{15}$ These two complexes were evaluated for their anticancer activity by Clarke in $1980 .{ }^{16}$ However, their poor aqueous solubility prevented their clinical use. $^{15,6}$

It is believed that both $\mathrm{Ru}(\mathrm{II})$ and $\mathrm{Ru}(\mathrm{III})$ anticancer complexes exhibit a novel mechanism of action that is independent of DNA binding. ${ }^{4}$ One example is the preclinical $\mathrm{Ru}(\mathrm{II})$ compound, $\left[\mathrm{Ru}\left(\eta^{6}-p\right.\right.$-cymene $\left.)(\mathrm{PTA}) \mathrm{Cl}_{2}\right]$ (RAPTA-C; PTA = 1,3,5-triaza-7-phosphaadamantane (RAPTA-C) which is reported to demonstrate antitumor activity by binding two protein targets, thioredoxin reductase and cathepsin $\mathrm{B} .{ }^{62}$ Thioredoxin reductase is a flavoenzyme that, together with thioredoxin (Trx) and reduced nicotinamide adenine dinucleotide phosphate (NADPH), make and maintains cellular redox state. Cathepsin B is also a cysteine peptidase capable of degrading components of the extracellular matrix in diseases such as muscular dystrophy and rheumatoid arthritis. It has been proposed that cathepsin B function together with other cysteine cathepsins, in metastasis, angiogenesis, and tumor progression. ${ }^{3,62}$

However, ruthenium(II) compound $\left[\mathrm{Ru}(\mathrm{II})\left(\eta^{6}\right.\right.$-biphenyl $\left.) \mathrm{Cl}(\mathrm{en})\right] \mathrm{PF}_{6}(\mathrm{RM} 175$; en = ethylenediamine), is reported to show a strong binding preference to DNA but not sulfur- or nitrogen-containing biomolecules. Unlike cisplatin, RM175 forms a distinct type of adduct with DNA that is more resistant to DNA repair mechanisms. Furthermore, RM175 does not 
demonstrate any in vitro or in vivo cross-resistance in cisplatin-resistant A2780cis ovarian carcinoma, indicating a different mode of action as relative to cisplatin.

The mechanism of the $\mathrm{Ru}(\mathrm{III})$ anticancer compounds are represented in Figure 5.
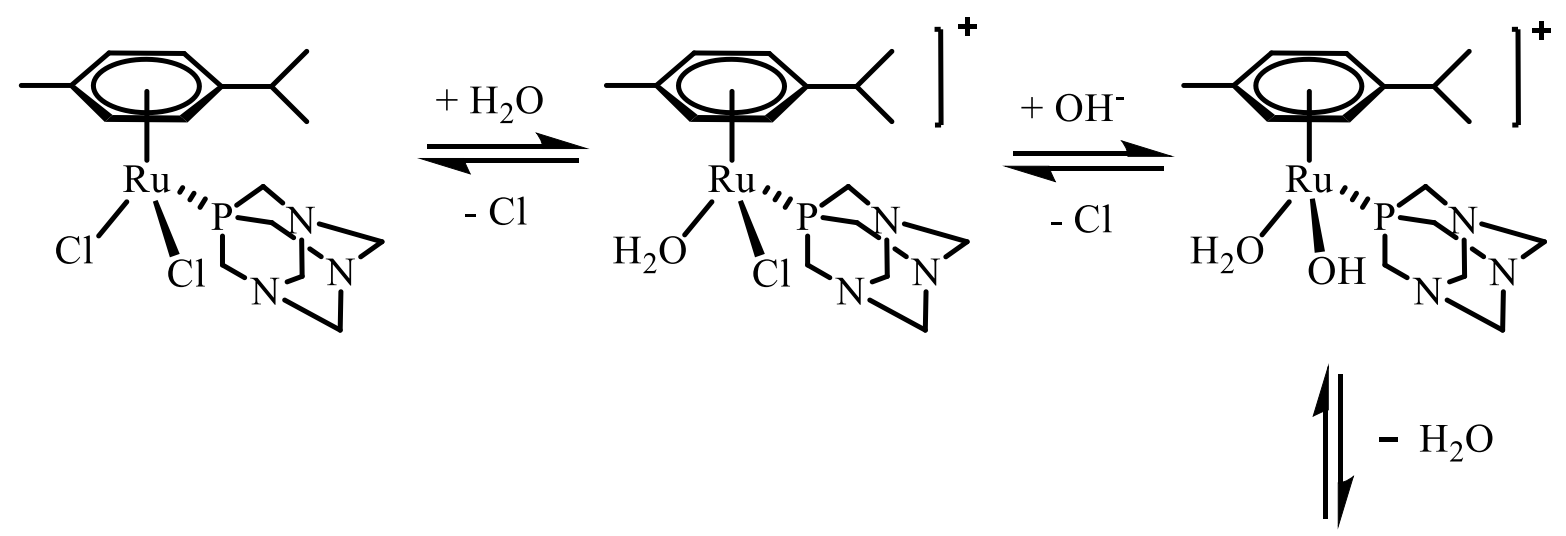

Anticancer Activity

Bind Target

Figure 5. Mechanism of action of RAPTA-C anticancer compounds.

Lastly, ruthenium can mimic iron in binding to the serum protein, transferrin. ${ }^{3}$

Transferrin is the main protein in the blood that binds to iron and transports it throughout the body. The binding behavior of ruthenium to transferrin is attributed to the fact that both iron and ruthenium appear in the same group on the periodic table. ${ }^{3}$

The first ruthenium complexes that were taken through clinical trials were those containing the indazole ligands which were synthesized by Keppler. These are the isoelectronic ruthenium(III) compounds $[\mathrm{imH}]$ trans $-\left[\mathrm{Ru}(N \text {-im })_{2} \mathrm{Cl}_{4}\right]$ and $[\mathrm{indH}]$ trans $-\left[\mathrm{Ru}(N \text {-ind })_{2} \mathrm{Cl}_{4}\right]$ (im= imidazole, ind $=$ indazole) which were active against several tumors models, especially against platinum- resistant colorectal autochthonous tumors. ${ }^{16}$ 


\section{Ruthenium(II) Arene Anticancer Compounds}

In 1992, Tocher et al. proposed the idea of using arene ruthenium compounds as anticancer agents which were subsequently pioneered by Dyson and Sadler. ${ }^{12,13}$ Arene $\mathrm{Ru}(\mathrm{II})$ complexes (Figure 6) have the general formula $\left[\left(\eta^{6}\right.\right.$-arene $\left.) \mathrm{Ru}(\mathrm{X})(\mathrm{Y})(\mathrm{Z})\right]$, where the arene rings include benzene (ben), methylisopropyl benzene (cym), biphenyl (bip) and dihydroanthracene (dha). The ligands $\mathrm{X}$ and $\mathrm{Y}$ are either two monodentate ligands or one bidentate ligand, and $\mathrm{Z}$ is most commonly a leaving group, such as a halogen. ${ }^{44,48}$

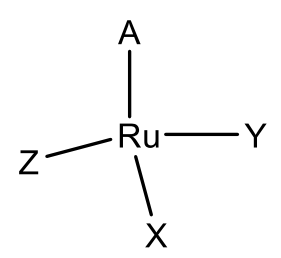

a

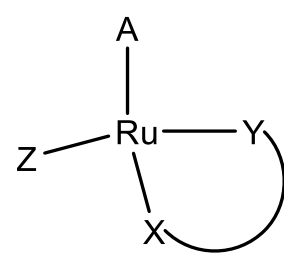

b

Figure 6. The general structure of $\mathrm{Ru}(\mathrm{II})$ arene complexes, (a)contains one bidentate ligand or (b) one monodentate ligand and one bidentate ligand, where $\mathrm{A}$ is an arene ring, and $\mathrm{X}, \mathrm{Y}$ and $\mathrm{Z}$ are ligands.

This synthesis of Ru arene complexes for cancer therapy has gained prominence due to the amphiphilic properties of the complexes. The hydrophobic arene ligand is balanced by the hydrophilic metal center, which can coordinate to water molecules. Additionally, the monodentate and bidentate ligands around the metal center form an important scaffold that can be modified to produce new class of compounds. These ligands around the metals are important for interacting with biological targets such as proteins and DNA in chemotherapy. ${ }^{12,13}$

In the structure of $\mathrm{Ru}(\mathrm{II})$ arene compounds, the arene moiety is considered the main component of arene $\mathrm{Ru}(\mathrm{II})$ complexes. The arene ring is hydrophobic, which enhances the permeation of $\mathrm{Ru}(\mathrm{II})$ complexes into cells as well as stabilizes the complex by establishing the 
18-electron configuration of the complex. ${ }^{14,15}$, However, the concentration of $\mathrm{Z}\left(\mathrm{Z}=\mathrm{Cl}^{-}, \mathrm{Br}^{-}, \mathrm{I}^{-}\right)$ and the $\mathrm{pH}$ of the tumor environment are two factors that affect the hydrolysis of $\mathrm{Ru}-\mathrm{Z}$ bonds. In the case of chlorido complexes, high extracellular chloride concentration (103 $\mathrm{mM})$ prevents aquation outside the cell so the hydrolysed products predominantly form inside the cell. Intracellular chloride ion concentration of the nucleus (4 mM) and cytoplasm $(23 \mathrm{mM})$ enhance the exchange of the chloride ligands inside the cell. This result suggests a selective mechanism of activation of Ru-chlorido complexes. ${ }^{9}$, The pKa of the environment of the complex also determines whether the more active $\mathrm{Ru}-\mathrm{OH}_{2}$ or the less active $\mathrm{Ru}-\mathrm{OH}$ predominates. ${ }^{9}$ pKa values of most aquated Ru-arene complexes are around 8, indicating that, the dominant species at physiological $\mathrm{pH}(7.4)$ in the blood are aquated products. ${ }^{9}$

Unlike $\mathrm{Pt}(\mathrm{II})$ compounds which are square planar, $\mathrm{Ru}(\mathrm{II})$ organometallic complexes are typically octahedral. Two groups of organometallic ruthenium(II) complexes, the RAPTA type has the 1,3,5-triaza-7-phosphaadamantane (PTA) ligand whereas the ruthenium arene ethylenediamine RAED type contains the ethylenediamine (en) ligand. Both compounds have shown promising anticancer activities. The RAPTA class of compounds have the structure $\left[\left(\eta^{6}-\right.\right.$ arene) $\mathrm{RuCl}_{2}$ (pta)], where pta =1,3,5-triaza-7-phosphaadamantane and the RAED class also have the structure, $\left[\left(\eta^{6} \text {-arene }\right) \mathrm{Ru}(\mathrm{en})-(\mathrm{Cl})\right]^{+}$where, arene $=$p-cymene, biphenyl, tetrahydroanthrance and en = ethylenediamine. ${ }^{15}$ The RAPTA class of compounds show low cytotoxicity in vitro but exhibit antimetastatic properties. These compounds do not show selective in vitro binding to DNA, proteins or RNA but inhibit cell growth by inducing apoptosis through $\mathrm{G}_{2} / \mathrm{M}$ disruption. ${ }^{10}$ The $\mathrm{G}_{2}$ phase is a period in the cell cycle characterized by protein synthesis and rapid cell growth to prepare the cell for mitosis.

The RAED class of compounds however, show the ability to bind to DNA and form adducts with guanine and exhibit potent cytotoxicity in vitro interaction with DNA. ${ }^{3}$ 
Two prominent examples of the RAPTA and RAED types of Ru(II) arene compounds are RAPTA-C and RM175 (Figure 7). ${ }^{49}$

RAPTA-type complex

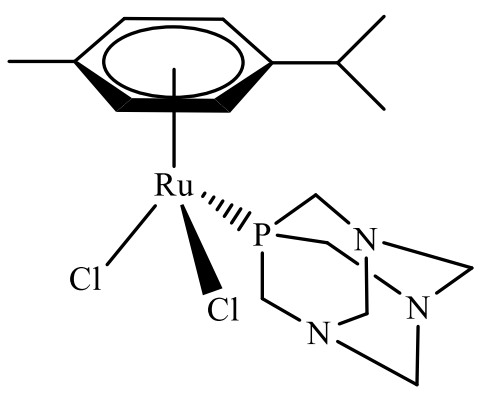

RAPTA- C
RAED-type complex

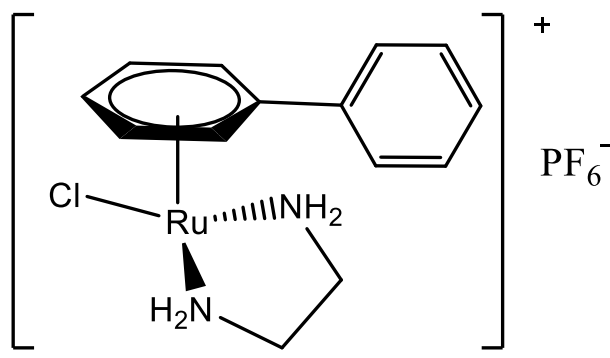

RM175

Figure 7. RAPTA-C and RM175 compounds.

RAPTA-C is a piano-stool ruthenium(II) arene complex developed by the Dyson group which has an amphiphilic PTA ligand, two labile chloride ligands, and a $\eta^{6}$-coordinated arene. ${ }^{50}$ The PTA ligand does not exhibit high sterical properties and is believed to enhance water solubility of RAPTA-C. ${ }^{45,51}$

Like cisplatin and other metal-based anticancer drugs, the first step in the mechanism of action of RAPTA-C is believed to be ligand exchange with water molecules within the cells. RAPTA-C undergoes rapid hydrolysis of a $\mathrm{Ru}-\mathrm{Cl}$ bond comparable to the ligand exchange kinetics of cisplatin in buffered water $\left(1.62 \times 10^{-5} \mathrm{~s}^{-1}\right)$. The compound exchanges one or two chloride ligands (Figure 5) with water and subsequently loses the aqua ligand allowing the molecule to bind to its target.

At low intracellular chloride concentrations of $4-5 \mathrm{mM}$, the most commonly formed product is the mono-aquated complex, $\left[\mathrm{Ru}(\mathrm{p} \text {-cymene }) \mathrm{Cl}\left(\mathrm{H}_{2} \mathrm{O}\right)(\mathrm{PTA})\right]^{+}$. At a $100 \mathrm{mM}$ chloride ion concentration similar to that of blood, hydrolysis of $\mathrm{Ru}-\mathrm{Cl}$ bond is not observed. RAPTA-C 
is therefore, considered a pro-drug that requires to be activated in its di-chlorido form just like cisplatin. ${ }^{14,15}$

Preliminary in vitro studies with RAPTA-C using TS/A mouse mammary adenocarcinoma cells did not show significant activity with $\mathrm{IC}_{50}$ greater than $300 \mu \mathrm{M}$. Similarly, studies with non-cancerous epithelial (HBL-100) cell lines also yielded $\mathrm{IC}_{50}$ values ranging from 66 to over $300 \mu \mathrm{M}$. Further investigation using mice however, showed that RAPTA-C inhibited tumor growth by about $75 \%{ }^{16,17}$ Analyses of the treated tumor found strong anti-angiogenic properties of the compound. That is, RAPTA-C is able to inhibit the formation of new blood vessels from pre-existing ones.

In a study involving cisplatin and RAPTA-C, despite cisplatin and RAPTA-C having similar leaving group chloride ligand and similar ligand exchange kinetics in water, RAPTA-C appeared more inert to extracellular reactions compared to cisplatin. ${ }^{18}$ This study further revealed that, RAPTA-C was found to predominantly bind albumin, a small molecule transporter in blood plasma. ${ }^{18}$ This result may indicate a selective mechanism of action of RAPTA-C.

The RAED complex RM175, [Ru(biphenyl)Cl(en) $]^{+}$was amongst the first ruthenium(II) complexes that were investigated for anticancer activity. This organometallic complex was developed by the Sadler group in 2001. ${ }^{19,20}$ Biological studies of the complex has revealed binding to DNA in addition to other cellular targets such as the inhibition of matrix metalloproteinase-2 (MMP-2). MMP-2 is an important class of metalloproteinases that contribute to tumor growth by controlling the microenvironment of the tumor and uses signaling pathways to modulate cell growth and angiogenesis. ${ }^{19,21}$

Similar to RAPTA-C, RM175 is activated by ligand exchange of a chloride ligand with water at the monodentate site. The aquation reaction facilitates covalent binding to the N7 of 
guanine in the DNA double helix. The arene moiety in this complex enhances hydrophobic interactions between RM175 and DNA by arene-intercalation between DNA base pairs. ${ }^{21}$ RM175 also exhibits anticancer activity by altering the processes of cell invasion and migration. The ruthenium complex is reported to be more potent against metastases over primary tumors, and the efficacy is found to be affected by the amount of the administered dose. It is reported that a dose of $10 \mathrm{mg} / \mathrm{kg} / \mathrm{day}$ resulted in an $85-95 \%$ reduction in metastatic mass, but only a $70 \%$ reduction was observed at a lower dose of $7.5 \mathrm{mg} / \mathrm{kg} / \mathrm{day} .{ }^{22} \mathrm{RM} 175$ is also reported to exhibit elevated response towards cytotoxicity and reduced cell viability when human serum albumin (HSA) in ratios from 1:1 to 1:10 was used to supplement the dose. Therefore, it has been suggested that the efficacy of RM175 may be greater in vivo than in vitro. ${ }^{19,22}$

Currently, the leading Ru(II) compound for therapeutic development is TLD1433

(Figure 8) which has entered phase I/2a of clinical trials for the treatment of nonmuscle invasive bladder cancer treatment with photodynamic therapy (PDT). ${ }^{17}$ PDT involves the activation of a photosensitizer drug by a specific wavelength of light. This subsequently causes cell destruction due to generation of the free radicals that can further produce reactive oxygen species (ROS) and/or singlet oxygen. TLD1433 contains $\pi$-expansive organic chromophores attached to 1,10 phenanthroline ligand. The compound is characterized by low-lying triplet intraligand excited states with prolonged lifetimes ranging from tens to hundreds of microseconds. This makes it sensitive to trace oxygen and other quenchers and promotes the generation of cytotoxic ROS, singlet oxygen $\left({ }^{1} \mathrm{O}_{2}\right)$ yielding very potent PDT effects even at low oxygen pressure. ${ }^{25}$ 


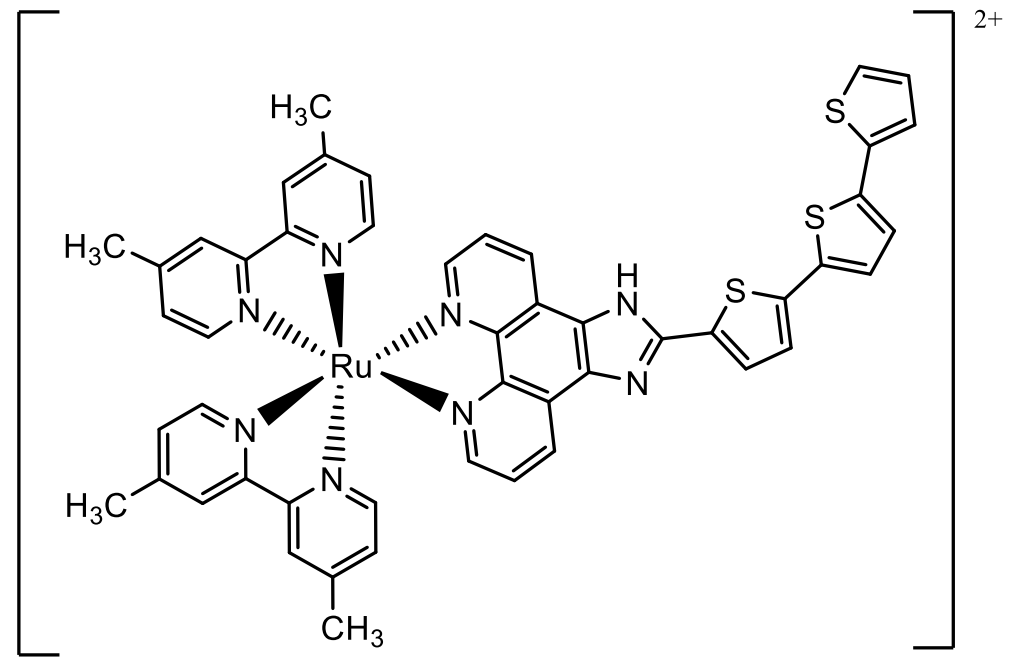

Figure 8. The structure of the Ru(II) complex TLD1433.

\section{Thesis Research}

Despite the many side effects associated with the use of platinum compounds in cancer therapy, clinical treatments rely heavily on these drugs as there are no better alternatives yet. This research focuses on the design and synthesis of novel ruthenium compounds that will be evaluated for their anticancer activity. The targeti compounds will be derivatives of the RAED family of Ru(II) complexes containing modular Schiff base ligands.

Schiff bases, named after Hugo Schiff, are formed when primary amine reacts with an aldehyde or a ketone under specific conditions. Schiff bases are versatile compounds that can easily be modified. ${ }^{34}$ In terms of structure, a Schiff base, also called imine or azomethine $(-\mathrm{C}=\mathrm{N}-)$, is a nitrogen analogue of an aldehyde or ketone. Schiff bases have achieved prominence in medicinal and pharmaceutical fields due to a broad spectrum of biological activities like anti-inflammatory, analgesic, antimicrobial, and anticancer activities. ${ }^{34,35}$.

The first part of the proposed work involves the syntheses of Schiff bases (Figure 9) by the reaction of aniline, 4-ferrocenyl aniline, and amino ferrocene with 2-acetylpyridine and 2- 
pyridinecarboxaldehyde respectively. The ligands were designed to include ferrocene given its favorable pharmacological properties.
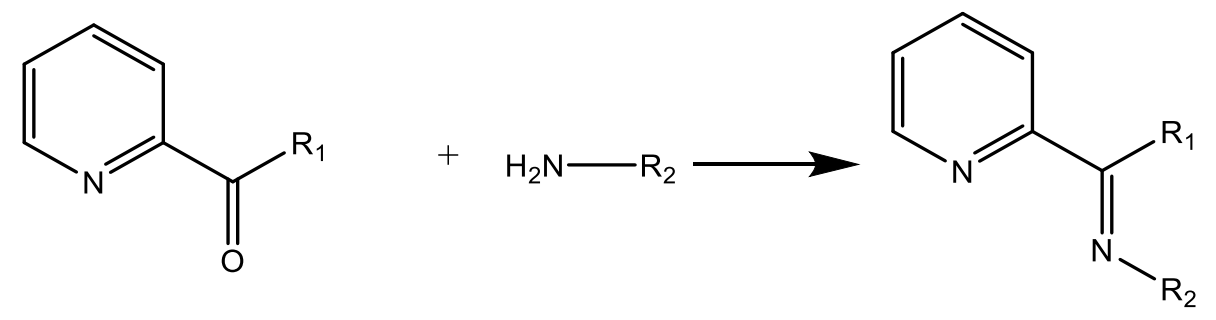

$\mathrm{R}_{1}=\mathrm{H}$ or $\mathrm{CH}_{3}$
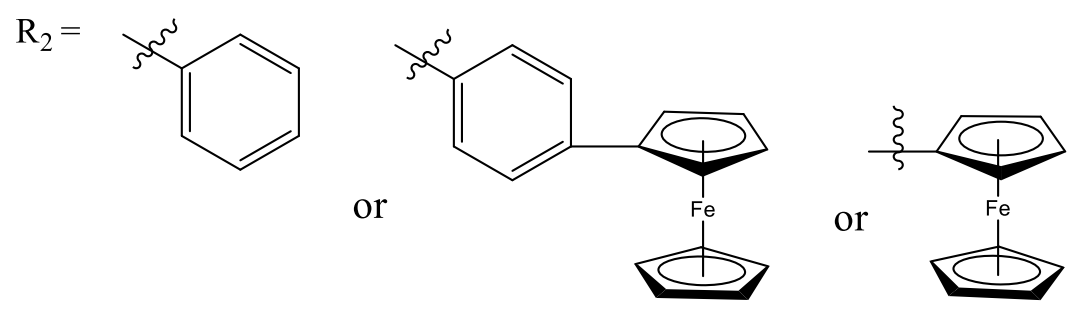

Figure 9. Synthetic routes of the target Schiff base ligands.

Ferrocenyl compounds such as aminoferrocenes have been investigated on human normal and cancer cells and have shown low toxicity, significant stability and lipophilicity, and unique electrochemical behavior. ${ }^{31}$ This has led to increasing research into the use of ferrocenecontaining compounds for medicinal applications. ${ }^{31}$ The Fe(II) core of ferrocene potentiates the generation of toxic ROS. The enhancement of the lipophilicity of organic drugs modulates the adsorption, distribution, metabolism, excretion, and toxicity properties of the original organic compounds that are modified. ${ }^{31}$ For example, ferroquine which is a ferrocene derivative of chloroquine, is active against chloroquine-resistant Plasmodium falciparum strains where chloroquine is inactive. 
Once the Schiff base ligands have been prepared and characterized, (CHAPTER TWO) they will be coordinated to Ru to make new complexes (CHAPTER THREE) and finally preliminary evaluations of the interactions between the complexes and the serum protein albumin will be conducted (CHAPTER FOUR). The compounds will be characterized using proton nuclear magnetic resonance spectroscopy $\left({ }^{1} \mathrm{H}\right.$ NMR), elemental analysis, Ultra Violet/Visible spectroscopy (UV/Vis), and electrospray ionization high resolution mass spectrometry (ESIHRMS). The generic structure of the target $\mathrm{Ru}(\mathrm{II})$ compounds in this research work are given Figure 10.

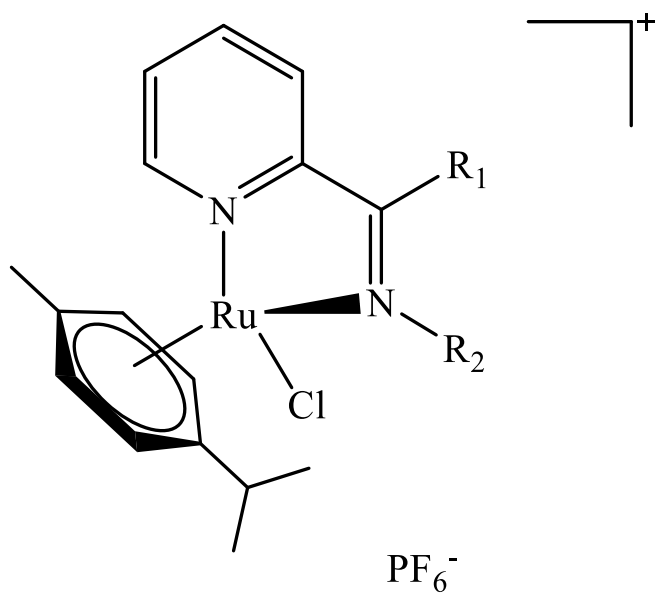

$\mathrm{R}_{1}=\mathrm{H}$ or $\mathrm{CH}_{3}$
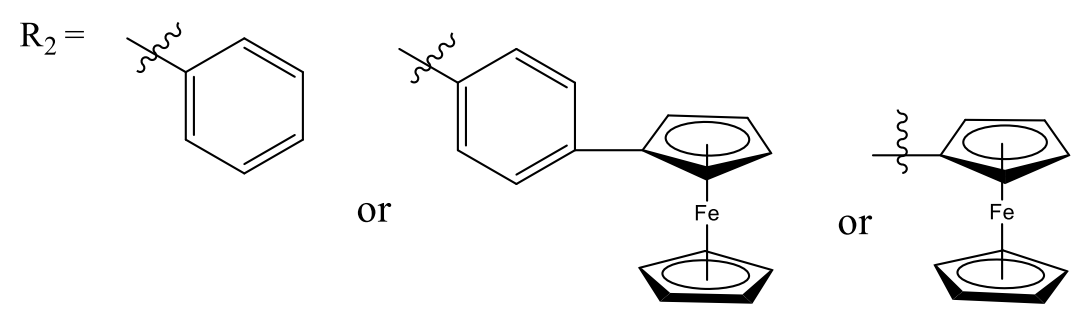

Figure 10. Generic structure of proposed $\mathrm{Ru}(\mathrm{II})$ compounds 


\section{CHAPTER II: SYNTHESES AND CHARACTERIZATION OF SIX \\ SCHIFF BASE LIGANDS}

\section{Introduction}

Schiff bases are compounds that contain imine or azomethine $(-\mathrm{C}=\mathrm{N}-)$ functional groups. These compounds are the condensation reaction products of primary amines with carbonyl compounds that were first synthesized by Hugo Schiff in $1864 .{ }^{33,34}$ The general reaction scheme for the syntheses of Schiff bases is presented in Figure 12 .

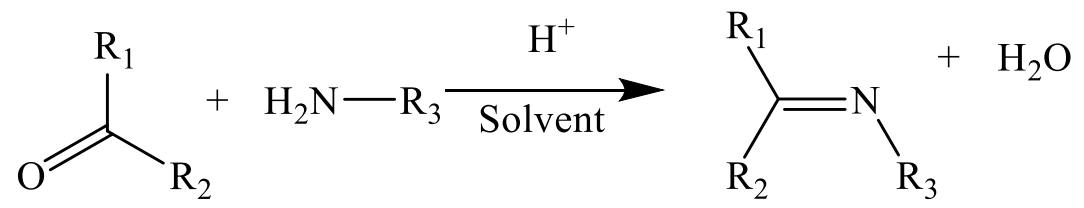

Figure 11. The general reaction scheme for Schiff base syntheses where, $R_{1}, R_{2}$, and $R_{3}$ are any organic chain.

Schiff bases are one of the most commonly used classes of organic compounds. ${ }^{33}$ Schiff bases have been shown to exhibit a broad range of biological activities, including antifungal, antibacterial, anti-malarial, antiproliferative, anti-inflammatory, antiviral, and antipyretic properties. ${ }^{33,34}$ One example is fluoroquinolone (Figure 12) which was evaluated for in vitro antitumor activity against a murine leukemia cell line (L1210), and a human leukocytoma cell line (HL60) demonstrating potent cytotoxic effects. 
<smiles>C[C@@H]1COc2c(N3CCN(C)CC3)c(F)cc3c(=O)c(-c4nnc(S)n4/N=C/c4ccccc4O)cn1c23</smiles>

Figure 12. Fluoroquinolone, an anticancer Schiff base compound.

Schiff bases have been used to form coordination complexes with a variety of metals. ${ }^{33}$ Schiff bases ligands with nitrogen and oxygen donor atoms are useful chelating agents for both transition and non-transition metal ions. ${ }^{33}$

Organoruthenium-based paullone complexes, which are ruthenium(II) arene Schiff base complexes have also been shown to possess potent anticancer properties against the ovarian cancer cell line, A2780. Examples of these compounds are shown in Figure 13.

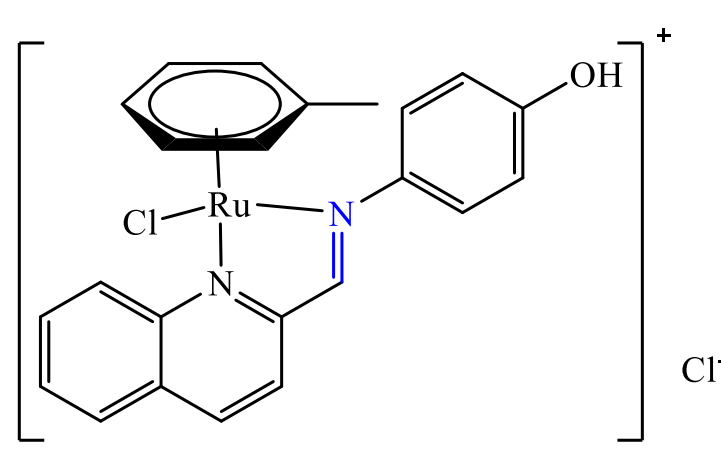

$\mathbf{a}$

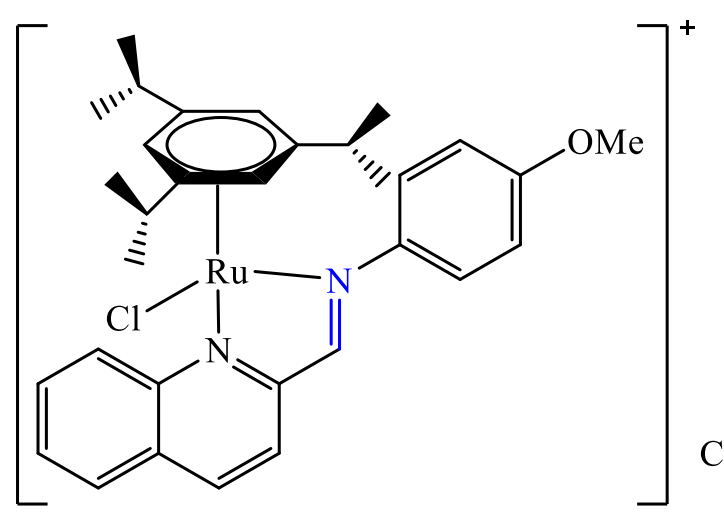

b

Figure 13. Organoruthenium-based paullone anticancer complexes 
Compound a in Figure 13 showed cytotoxic properties against A2870 cell with the concentration at $50 \%$ inhibition $\left(\mathrm{IC}_{50}\right)$ comparable to that of cisplatin. Complex $\mathbf{b}$ however, had $\mathrm{IC}_{50}$ that was 3 times lower than that of cisplatin indicating a higher activity relative to cisplatin. Following the efficacy of the reported N-N ligands, this part of the research deals with syntheses of N-N Schiff base compounds that will then be used as ligands to synthesize the ruthenium(II) target compounds. Six Schiff base ligands $\left(\mathbf{L}_{\mathbf{1}}-\mathbf{L}_{\mathbf{6}}\right)$ were synthesized by reaction of each of three primary amines - aniline, aminoferrocene, and 4-ferrocenylaniline with either 2acetylpyridine or 2-pyridinecarboxaldehyde (Table 1). Whereas the $\mathbf{L 1}$ and $\mathbf{L 2}$ have been previously reported,${ }^{37}$ the four other Schiff base ligands (L3-L6) are novel compounds. These proposed ligands (Figure 14) are N-N bidentate ligands as found in RAED compounds. Since the discovery of ferrocene in 1951, the favorable electronic properties of ferrocene and its easy functionalization, makes the compound useful for wide range of applications in materials science.${ }^{37}$ The stability of ferrocene in aqueous and aerobic media, and its unique electrochemical properties have made ferrocenyl compounds very useful molecules for biological applications. The anticancer properties of ferrocenyl compounds containing amine or amide groups were first studied in the late 1970s, using lymphocytic leukemia P-388 cells. ${ }^{37}$

\begin{tabular}{cll}
\hline Ligand & \multicolumn{1}{c}{ Pyridine } & \multicolumn{1}{c}{ Primary Amine } \\
\hline L1 & 2-Acetylpyridine & Aniline \\
L2 & 2-Pyridinecarboxaldehyde & Aniline \\
L3 & 2-Acetylpyridine & 4-Ferrocenylaniline \\
$\mathbf{L 4}$ & 2-Pyridinecarboxaldehyde & 4-Ferrocenylaniline \\
L5 & 2-Acetylpyridine & Aminoferrocene \\
L6 & 2-Pyridinecarboxaldehyde & Aminoferrocene \\
\hline
\end{tabular}

Table 1. The six Schiff base ligands and the reagents that were combined to make them. 
<smiles>C/C(=N\c1ccccc1)c1ccccn1</smiles><smiles>C(=N/c1ccccc1)\c1ccccn1</smiles><smiles>C/C(=N\c1ccc(C2CC=CC2C2CC2)cc1)c1ccccn1</smiles><smiles>Fc1cccc(-c2ccc(/N=C/c3ccccn3)cc2)c1</smiles><smiles>C/C(=N\c1ccccc1F)c1ccccc1</smiles>

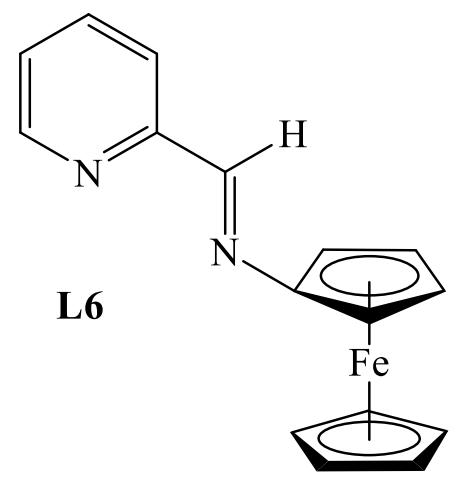

Figure 14. Structures of the target Schiff base ligands.

It is reported that the inclusion of ferrocene into a drug scaffold improves the lipophilicity of organic drugs, thereby modifying the adsorption, distribution, metabolism, excretion, and toxicity properties of the original organic compounds. Due to the drug enhancement properties of ferrocene, it will be incorporated into four of the proposed Schiff bases. 


\section{Experimental}

\section{General materials and methods}

The reagents utilized were purchased from Fisher Scientific, Sigma Aldrich, Cambridge Isotope Laboratories or Oakwood Chemical. All chemicals acquired were used as received. The ${ }^{1} \mathrm{H}$ NMR of the ligands were all measured with 16 scans, and field centered at 6 ppm, a sweep width of $20 \mathrm{ppm}$, and a delay time of 1 second. The mass spectra of the ligands were collected using ESI-HRMS.

\section{Instrumentation}

The ${ }^{1} \mathrm{H}$ NMR spectra of the Schiff base ligands compounds were collected using a Bruker Avance III $400 \mathrm{MHz}$ NMR spectrometer with either deuterated chloroform $\left(\mathrm{CDCl}_{3}\right)$ or deuterated dimethylsulfoxide (DMSO- $\mathrm{d}_{6}$ ) as the solvent. The ${ }^{1} \mathrm{H}$ NMR spectra of these compounds were processed using the Topspin 2.1 software. The mass spectra of the ligands were measured using a Thermo Fischer Q Exactive mass spectrometer equipped with Thermo Q Exactive software which were used to process the data. The UV-vis spectra of the Schiff base ligands were collected using an Evolution 260 Bio Spectrophotometer equipped with a single cell Peltier system and a Haake DC 10 pump. The software on which the experiments were run was the Thermo INSIGHT software.

$N$-[(Pyridin-2-yl)ethylidene]aniline (L1)

2-Acetylpyridine (1.58 mL, $14.1 \mathrm{mmol})$ and aniline (1.29 mL, $14.2 \mathrm{mmol})$ were combined in a round bottom flask. Anhydrous toluene $(7 \mathrm{~mL})$ was then added and the reaction mixture heated at $120^{\circ} \mathrm{C}$ (reflux) for 16 hours. The reaction mixture was then allowed to cool, and the solvent was removed completely using the rotary evaporator. Yield: $86 \%(2.39 \mathrm{~g})$. $\mathrm{C}_{13} \mathrm{H}_{13} \mathrm{~N}_{2}{ }^{+}$ESI-HRMS: m/z 197.1079, calculated 197.1079, ${ }^{1} \mathrm{H}$ NMR $\delta=\left(400 \mathrm{MHz}, \mathrm{CDCl}_{3}\right)$ : 8.59 (d, 1H, 
Py- $\left.\mathrm{H}^{6}\right), 8.20\left(\mathrm{~d}, 1 \mathrm{H}, \mathrm{Py}-\mathrm{H}^{3}\right), 7.71\left(\mathrm{td},{ }^{1} \mathrm{~J}=6.08 \mathrm{~Hz},{ }^{2} \mathrm{~J}=2.17 \mathrm{~Hz}, 1 \mathrm{H}\right.$, Py- $\left.\mathrm{H}^{4}\right), 7.30(\mathrm{~m}, 1 \mathrm{H}$, Py$\left.\mathrm{H}^{5,8}\right), 7.10\left(\mathrm{~m}, 3 \mathrm{H}, \mathrm{Ph}-\mathrm{H}^{9}\right), 6.76\left(\mathrm{~d}, 2 \mathrm{H} \mathrm{Ph}-\mathrm{H}^{7}\right), 2.67$ (s, 3H, $\left.\mathrm{CH}_{3}\right)$. $N$-[(Pyridin-2-yl)methylidene]aniline (L2)

First, 2-pyridinecarboxaldehyde $(0.68 \mathrm{~mL}, 7.15 \mathrm{mmol})$ and aniline $(0.65 \mathrm{~mL}, 7.13$ mmol) were combined in a round bottom flask. To the mixture, anhydrous toluene $(7 \mathrm{~mL})$ was then added. The reaction mixture was heated to $120^{\circ} \mathrm{C}$ (reflux) for 16 hours. The reaction mixture was then allowed to cool, and the solvent was removed completely using the rotary evaporator. Yield: $92 \%$ (1.32 g). $\mathrm{C}_{12} \mathrm{H}_{11} \mathrm{~N}_{2}{ }^{+}$ESI- HRMS m/z: 183.0922, Calculated: 183.0922 ${ }^{1} \mathrm{H}$ NMR $\delta=\left(400 \mathrm{MHz}, \mathrm{CDCl}_{3}\right): 8.65\left(\mathrm{dq},{ }^{1} \mathrm{~J}=4.81 \mathrm{~Hz},{ }^{2} \mathrm{~J}=0.84 \mathrm{~Hz}, 1 \mathrm{H}, \mathrm{Py}-\mathrm{H}^{6}\right), 8.54(\mathrm{~s}, 1 \mathrm{H}$, $\mathrm{CH}=\mathrm{N}), 8.14\left(\mathrm{dt},{ }^{1} \mathrm{~J}=7.94 \mathrm{~Hz},{ }^{2} \mathrm{~J}=1.05 \mathrm{~Hz}, 1 \mathrm{H}, \mathrm{Py}-\mathrm{H}^{3}\right), 7.35\left(\mathrm{~m}, 1 \mathrm{H}, \mathrm{Py}-\mathrm{H}^{4}\right), 7.77\left(\mathrm{td},{ }^{1} \mathrm{~J}=\right.$ $\left.7.70,{ }^{2} \mathrm{~J}=1.70 \mathrm{~Hz}, 1 \mathrm{H}, \mathrm{Py}-\mathrm{H}^{5}\right), 7.4-6.61\left(\mathrm{~m}, 5 \mathrm{H}, \mathrm{Ph}-\mathrm{H}^{7,8,9,10,11}\right)$.

\section{4-Nitrophenylferrocene}

A suspension of 4-nitroaniline $(2.80 \mathrm{~g}, 20.0 \mathrm{mmol})$ in water $(3 \mathrm{~mL})$ and concentrated hydrochloric acid $(6 \mathrm{~mL})$ was cooled to $0{ }^{\circ} \mathrm{C}$. Then, sodium nitrite $(1.41 \mathrm{~g}, 20.0 \mathrm{mmol})$ in water $(4 \mathrm{~mL})$ was added dropwise. The mixture was then stirred for 30 minutes to obtain $p$ nitrobenzenediazonium chloride. In another flask, ferrocene (1.90 g, $10.0 \mathrm{mmol})$, and hexadecyltrimethylammonium bromide $(2.01 \mathrm{~g}, 0.550 \mathrm{mmol})$ in diethyl ether $(20.0 \mathrm{~mL})$ was cooled to $0-5{ }^{\circ} \mathrm{C}$ and stirred continuously. To this stirring system the prepared $p$ nitrobenzenediazonium chloride suspension was then added dropwise. The reaction mixture was then stirred for 5 hours. The solvent was then removed using the rotary evaporator and the residue was washed with water $(2 \times 6 \mathrm{~mL})$ and hexane $(6 \mathrm{~mL})$. The solid product obtained was recrystallized from petroleum ether and 4-nitrophenylferrocene was obtained as dark violet 
plates. Yield: $89 \%(2.81 \mathrm{~g}) .{ }^{1} \mathrm{H}$ NMR $\delta=\left(\mathrm{CDCl}_{3}, 400 \mathrm{MHz}, \mathrm{ppm}\right): 8.14\left(\mathrm{~d}, 2 \mathrm{H}, \mathrm{C}_{6} \mathrm{H}_{4}\right), 7.78(\mathrm{~d}$, $\left.2 \mathrm{H}, \mathrm{C}_{6} \mathrm{H}_{4}\right), 5.00\left(\mathrm{~s}, 2 \mathrm{H}, \mathrm{C}_{5} \mathrm{H}_{4}\right), 5.54\left(\mathrm{~s}, 2 \mathrm{H}, \mathrm{C}_{5} \mathrm{H}_{4}\right) 4.067\left(\mathrm{~s}, 5 \mathrm{H}, \mathrm{C}_{5} \mathrm{H}_{5}\right)$.

\section{4-Ferrocenylaniline}

The prepared 4-nitrophenylferrocene $(0.250 \mathrm{~g}, 0.820 \mathrm{mmol})$ was dissolved in ethanol $(5.20 \mathrm{~mL})$ in a round bottom flask. Concentrated $\mathrm{HCl}(3.00 \mathrm{~mL})$ and granulated tin $(0.600 \mathrm{~g}, 5.05$ mmol) were then added. The reaction mixture was heated under reflux for 4.5 hours. After refluxing, the resulting solution was cooled to room temperature and distilled water $(17.0 \mathrm{~mL})$ was added, and the $\mathrm{pH}$ was adjusted to 14 with aqueous $\mathrm{NaOH}$. The granulated tin was then filtered off and the filtrate was extracted using $\mathrm{CH}_{2} \mathrm{Cl}_{2}$ as the mobile phase and dried over anhydrous $\mathrm{Na}_{2} \mathrm{SO}_{4}$. The solvent was then removed on the rotary evaporator and the crude product was purified by column chromatography on silica gel using $\mathrm{CH}_{2} \mathrm{Cl}_{2}$ as the mobile phase. A major orange band corresponding to 4-ferrocenylaniline was eluted with $\mathrm{CH}_{2} \mathrm{Cl}_{2}$. The $\mathrm{CH}_{2} \mathrm{Cl}_{2}$ was removed using the rotary evaporator to obtain 4-ferrocenylaniline as a bright orange solid. Yield: $52 \%$ (0.12 g). ${ }^{1} \mathrm{H} \mathrm{NMR} \delta=\left(\mathrm{CDCl}_{3}, 400 \mathrm{MHz}, \mathrm{ppm}\right): 7.22\left(\mathrm{~d}, 2 \mathrm{H}, \mathrm{C}_{6} \mathrm{H}_{4},\right), 6.56(\mathrm{~d}, 2 \mathrm{H}$, $\left.\mathrm{C}_{6} \mathrm{H}_{4}\right), 4.46$ (s, 2H, $\left.\mathrm{C}_{5} \mathrm{H}_{4}\right), 3.96\left(\mathrm{~s}, 5 \mathrm{H}, \mathrm{C}_{5} \mathrm{H}_{5}\right), 3.55$ (br, 2H, $\left.\mathrm{NH}_{2}\right)$. $N$-\{[(Pyridin-2-yl)ethylidene]imino\}phenylferrocene (L3)

4- Ferrocenylaniline $(0.04 \mathrm{~g}, 0.130 \mathrm{mmol})$ and 2-acetylpyridine $(0.13 \mathrm{~g}, 1.07 \mathrm{mmol})$ were put in a round bottom flask and anhydrous toluene $(0.5 \mathrm{~mL})$ was added and the mixture was heated at $120^{\circ} \mathrm{C}$ for 5 hours. The solvent was then removed using the rotary evaporator under high vacuum. Yield: $42 \%$ (0.06 g) $\mathrm{C}_{23} \mathrm{H}_{21} \mathrm{~N}_{2} \mathrm{Fe}^{+}$ESI HRMS m/z: 381.2987, Calculated:

$381.10542,{ }^{1} \mathrm{H} \mathrm{NMR} \delta=\left(\mathrm{CDCl}_{3}, 400 \mathrm{MHz}\right) 8.60\left(\mathrm{dq}{ }^{1} \mathrm{~J}=4.84 \mathrm{~Hz},{ }^{2} \mathrm{~J}=0.97 \mathrm{~Hz}, 1 \mathrm{H} \mathrm{Py}-\mathrm{H}^{6},\right)$, $8.22\left(\mathrm{dt},{ }^{1} \mathrm{~J}=8.10 \mathrm{~Hz},{ }^{2} \mathrm{~J}=0.97 \mathrm{~Hz}, 1 \mathrm{H}, \mathrm{Py}-\mathrm{H}^{3}\right), 7.72\left(\mathrm{td},{ }^{1} \mathrm{~J}=7.89 \mathrm{~Hz},{ }^{2} \mathrm{~J}=1.81 \mathrm{~Hz}, 1 \mathrm{H}\right.$, Py$\left.\mathrm{H}^{4}\right), 7.42\left(\mathrm{~d}, 2 \mathrm{H}, \mathrm{C}_{6} \mathrm{H}_{4}\right), 7.29\left(\mathrm{td},{ }^{1} \mathrm{~J}=6.04 \mathrm{~Hz},{ }^{2} \mathrm{~J}=1.17 \mathrm{~Hz}, 1 \mathrm{H}, \mathrm{Py}-\mathrm{H}^{5}\right), 6.71\left(\mathrm{~d}, 2 \mathrm{H}, \mathrm{C}_{6} \mathrm{H}_{4}\right)$, 
$4.57\left(\mathrm{t}, 2 \mathrm{H}, \mathrm{C}_{5} \mathrm{H}_{4}\right), 4.24\left(\mathrm{t}, 2 \mathrm{H}, \mathrm{C}_{5} \mathrm{H}_{4}\right), 4.00\left(\mathrm{~s}, 5 \mathrm{H}, \mathrm{C}_{5} \mathrm{H}_{5}\right), 2.34(\mathrm{~s}, 1 \mathrm{H}, \mathrm{CH}=\mathrm{N})$.

\section{(2-\{[(Pyridinyl)methylidene $]$ imino $\}$ phenyl $)$ ferrocene $(\mathbf{L 4 )}$}

4-Ferrocenylaniline (1.01 g, $3.45 \mathrm{mmol})$ and 2-pyridinecarboxaldehyde (0.880 g, 12.1 mmol) were put into a round bottom flask and $\mathrm{CH}_{2} \mathrm{Cl}_{2}(1.00 \mathrm{~mL})$ was added and the resulting solution was stirred at room temperature for 2 hours. The solvent was removed on the rotary evaporator. To remove any water by-product, the temperature of the rotary evaporator was increased to $60^{\circ} \mathrm{C}$ and the regulator set to maximum vacuum after 5 minutes until an orange brown solid mass was formed in the flask. Yield: $91 \%(1.20 \mathrm{~g}) \mathrm{C}_{22} \mathrm{H}_{19} \mathrm{~N}_{2} \mathrm{Fe}^{+}$ESI HRMS m/z: 367.0912, Calculated: $367.08977{ }^{1} \mathrm{H}$ NMR $\delta=\left(\mathrm{CDCl}_{3}, 400 \mathrm{MHz}, 8.65\left(\mathrm{dq}^{1} \mathrm{~J}=4.85 \mathrm{~Hz},{ }^{2} \mathrm{~J}=\right.\right.$ 0.88, $1 \mathrm{H}$ Py-H $\left.\mathrm{H}^{6}\right), 8.61(\mathrm{~s}, 1 \mathrm{H}, \mathrm{CH}=\mathrm{N}), 8.15\left(\mathrm{dt},{ }^{1} \mathrm{~J}=7.94,{ }^{2} \mathrm{~J}=0.95,1 \mathrm{H}, \mathrm{Py}-\mathrm{H}^{3}\right), 7.75\left(\mathrm{td},{ }^{1} \mathrm{~J}=\right.$ $\left.7.76 \mathrm{~Hz},{ }^{2} \mathrm{~J}=1.68 \mathrm{~Hz}, 1 \mathrm{H}, \mathrm{Py}-\mathrm{H}^{4}\right), 7.45\left(\mathrm{~d}, 2 \mathrm{H}, \mathrm{C}_{6} \mathrm{H}_{4}\right), 7.29\left(\mathrm{td},{ }^{1} \mathrm{~J}=6.18 \mathrm{~Hz},{ }^{2} \mathrm{~J}=1.46 \mathrm{~Hz}, 1 \mathrm{H}\right.$, Py- $\left.\mathrm{H}^{5}\right), 7.21\left(\mathrm{~d}, 2 \mathrm{H}, \mathrm{C}_{6} \mathrm{H}_{4}\right), 4.59\left(\mathrm{t}, 2 \mathrm{H}, \mathrm{C}_{5} \mathrm{H}_{4}\right), 4.26\left(\mathrm{t}, 2 \mathrm{H}, \mathrm{C}_{5} \mathrm{H}_{4}\right), 3.99\left(\mathrm{~s}, 5 \mathrm{H}, \mathrm{C}_{5} \mathrm{H}_{5}\right)$.

\section{Ferrocenoyl azide}

Caution: Azides are explosive, so to prevent any pressure build-up, an empty Vigreux condenser was attached to the reaction flask and protected with a blast shield in the fume hood. In a $100 \mathrm{~mL}$ round bottom flask, anhydrous $\mathrm{CH}_{2} \mathrm{Cl}_{2}(20 \mathrm{~mL})$, ferrocenecarboxylic acid (2.00 g, $8.7 \mathrm{mmol})$, and oxalyl chloride $(1.50 \mathrm{~mL}, 17.4 \mathrm{mmol})$ were added and cooled to $0{ }^{\circ} \mathrm{C}$. The reaction mixture was stirred vigorously and a drop of dimethylformamide was added. The reaction was then allowed to warm to room temperature and stirred continuously for 3 hours. The reaction mixture was then concentrated under reduced pressure and the residue was taken up in anhydrous $\mathrm{CH}_{2} \mathrm{Cl}_{2}(20 \mathrm{~mL})$ and cooled to $0{ }^{\circ} \mathrm{C}$. Tetra-n-butylammonium bromide $(0.03 \mathrm{~g}, 0.09$ mmol) was then added followed by the addition of sodium azide $(0.850 \mathrm{~g}, 13.1 \mathrm{mmol})$ in distilled water $(4 \mathrm{~mL})$. The reaction mixture was then allowed to warm to room temperature and 
left to stir for 18 hours. The reaction was then quenched with distilled water $(20 \mathrm{~mL})$ and the organic layer was extracted twice with $\mathrm{CH}_{2} \mathrm{Cl}_{2}$. The combined organics were then dried over $\mathrm{MgSO}_{4}$ and concentrated under reduced pressure to yield the crude product. The product was then purified by silica gel column chromatography using (hexane $1: 1 \mathrm{CH}_{2} \mathrm{Cl}_{2}$ ) to give the compound as a crystalline orange solid. Yield: $85.8 \%,(1.91 \mathrm{~g}) .{ }^{1} \mathrm{H} \mathrm{NMR} \quad \delta=\left(\mathrm{CDCl}_{3}, 400\right.$ $\mathrm{MHz}), 4.75\left(\mathrm{t}, 2 \mathrm{H}, \mathrm{C}_{5} \mathrm{H}_{4}\right), 4.44\left(\mathrm{t}, 2 \mathrm{H}, \mathrm{C}_{5} \mathrm{H}_{4}\right), 4.19$ (s, 5H, $\left.\mathrm{C}_{5} \mathrm{H}_{5}\right)$.

\section{2-(Trimethylsilyl)ethyl ferrocenylcarbamate}

Anhydrous toluene $(3 \mathrm{~mL})$ was put in a $25 \mathrm{~mL} 3$-necked round bottom flask and ferrocenoyl azide $(0.250 \mathrm{~g}, 1.00 \mathrm{mmol})$ was added. Trimethylsilyl ethanol $(0.280 \mathrm{~mL}, 1.97$ mmol) was then added and the mixture was heated to reflux for 3 hours under nitrogen, resulting in a bright orange solution. After cooling to room temperature, the reaction mixture was transferred to a single necked round-bottom flask and concentrated under reduced pressure using the rotary evaporator to yield an orange solid mass of crude product. The product was purified by silica gel column chromatography using hexane and ethylacetate (EtOAc) (1:1) to give the product as a pale orange solid. Yield: $92 \%(0.270 \mathrm{~g}) .{ }^{1} \mathrm{H} \mathrm{NMR} \delta=\left(\mathrm{CDCl}_{3}, 400 \mathrm{MHz}\right) 8.63$ (s, br, 1H, NH), $4.40(\mathrm{~s}, 2 \mathrm{H}), 4.09-4.03(7 \mathrm{H}, \mathrm{m}), 3.86(\mathrm{t}, \mathrm{J}=1.85 \mathrm{~Hz}, 2 \mathrm{H}), 0.91(\mathrm{t}, 2 \mathrm{H}), 0.06(\mathrm{~s}, 9 \mathrm{H})$.

\section{Aminoferrocene}

2-(Trimethylsilyl)ethyl ferrocenecarbamate $(0.60 \mathrm{~g}, 1.8 \mathrm{mmol})$ was added to a solution of tetrabutylammonium fluoride (TBAF) solution (1M) in THF $(8 \mathrm{~mL}, 8 \mathrm{mmol})$ and the reaction mixture was heated to $50{ }^{\circ} \mathrm{C}$ for 2 hours. The reaction mixture was then allowed to cool to room temperature and concentrated under reduced pressure and the residue was quenched with water (20 mL), then extracted with $\mathrm{CH}_{2} \mathrm{Cl}_{2}(3 \times 20 \mathrm{~mL})$. The combined organics were dried over $\mathrm{MgSO}_{4}$ and concentrated under reduced pressure to yield the crude product. The product was 
then purified by silica gel column chromatography using hexane and EtOAc (8:2). Yield: $50 \%$ $(0.20 \mathrm{~g}) .{ }^{1} \mathrm{H} \mathrm{NMR} \delta=\left(400 \mathrm{MHz} \mathrm{CDCl}_{3}\right): 4.03\left(\mathrm{~s}, 5 \mathrm{H}, \mathrm{C}_{5} \mathrm{H}_{5}\right), 3.92\left(\mathrm{~s}, 2 \mathrm{H}, \mathrm{C}_{5} \mathrm{H}_{4}\right), 3.77(\mathrm{~s}, 2 \mathrm{H}$, $\left.\mathrm{C}_{5} \mathrm{H}_{4}\right), 2.5$ (s, br, $2 \mathrm{H}, \mathrm{NH}_{2}$ ).

\section{2-\{[(Pyridinyl)ethylidene]iminoferrocene (L5)}

Aminoferrocene $(0.10 \mathrm{~g}, 0.50 \mathrm{mmol})$ was dissolved in 2-acetylpyridine $(0.06 \mathrm{~g}, 0.50$ mmol). To this solution was added anhydrous toluene $(1 \mathrm{~mL})$ and the compounds were heated to reflux for a period of 12 hours. The mixture turned into a brown solution and the solvent was removed on the rotary evaporator yielding a sticky brown product that was difficult to take out of the flask product. ESI HRMS m/z: 305.07 Calculated: $305.07,{ }^{1} \mathrm{H} \mathrm{NMR} \delta=\left(400 \mathrm{MHz}, \mathrm{CDCl}_{3}\right)$ : $8.55\left(\mathrm{~d}, 1 \mathrm{H}, \mathrm{Py}-\mathrm{H}^{6}\right), 8.20\left(\mathrm{~d}, 1 \mathrm{H}, \mathrm{Py}-\mathrm{H}^{3}\right), 7.68\left(\mathrm{td},{ }^{1} \mathrm{~J}=7.69,{ }^{2} \mathrm{~J}=1.611 \mathrm{H}, \mathrm{Py}-\mathrm{H}^{4}\right), 7.23\left(\mathrm{dd},{ }^{1} \mathrm{~J}=\right.$ $\left.4.85 \mathrm{~Hz},{ }^{2} \mathrm{~J}=1.21 \mathrm{~Hz}, 1 \mathrm{H}, \mathrm{Py}-\mathrm{H}^{5}\right), 4.45\left(\mathrm{t}, 2 \mathrm{H}, \mathrm{C}_{5} \mathrm{H}_{4}\right), 4.20\left(\mathrm{t}, 2 \mathrm{H}, \mathrm{C}_{5} \mathrm{H}_{4}\right), 4.00\left(\mathrm{~s}, 5 \mathrm{H}, \mathrm{C}_{5} \mathrm{H}_{5}\right)$, $2.45\left(\mathrm{~s}, 3 \mathrm{H}, \mathrm{CH}_{3}\right)$.

\section{N-[(Pyridin-2-yl)methylidene]iminoferrocene (L6)}

2-Pyridinecarboxaldehyde (0.30 g, $2.77 \mathrm{mmol})$ and aminoferrocene (1.01 g, $2.77 \mathrm{mmol})$ were put in a round bottom flask. To this mixture, $\mathrm{CH}_{2} \mathrm{Cl}_{2}(0.50 \mathrm{ml})$ was added and the compounds were thoroughly stirred for a period of 12 minutes. The mixture turned into a red solution and the solvent was removed on the rotary evaporator to produce orange brown precipitate. Yield: $91.2 \%$ (1.23 g) product. Calculated: 291.09 ESI- HRMS m/z: 291.09, ${ }^{1} \mathrm{H}$ NMR $\delta=\left(400 \mathrm{MHz}, \mathrm{CDCl}_{3}\right): 8.68(\mathrm{~s}, 1 \mathrm{H}, \mathrm{CH}=\mathrm{N}), 8.60\left(\mathrm{dq},{ }^{1} \mathrm{~J}=4.79 \mathrm{~Hz},{ }^{2} \mathrm{~J}=0.94 \mathrm{~Hz} 1 \mathrm{H}\right.$, Py$\left.\mathrm{H}^{6}\right), 8.05\left(\mathrm{~d}, 1 \mathrm{H}, \mathrm{Py}-\mathrm{H}^{3}\right), 7.69\left(\mathrm{td},{ }^{1} \mathrm{~J}=6.15 \mathrm{~Hz},{ }^{2} \mathrm{~J}=1.65 \mathrm{~Hz}, 1 \mathrm{H}, \mathrm{Py}-\mathrm{H}^{4}\right), 7.26\left(\mathrm{dd},{ }^{1} \mathrm{~J}=3.69\right.$ $\left.\mathrm{Hz},{ }^{2} \mathrm{~J}=1.16 \mathrm{~Hz}, 1 \mathrm{H}, \mathrm{Py}-\mathrm{H}^{5}\right), 4.61\left(\mathrm{t}, 2 \mathrm{H}, \mathrm{C}_{5} \mathrm{H}_{4}\right), 4.26\left(\mathrm{t}, 2 \mathrm{H}, \mathrm{C}_{5} \mathrm{H}_{4}\right), 4.12\left(\mathrm{~s}, 5 \mathrm{H}, \mathrm{C}_{5} \mathrm{H}_{5}\right)$. 


\section{General UV-vis Experimental Conditions}

The stability of the compounds in 50\% DMSO and aqueous phosphate buffered saline (PBS) at $37^{\circ} \mathrm{C}$ and $\mathrm{pH}$ of 7.4 were determined using UV-vis spectroscopy over a period of 2 hours. The spectra of the compounds were measured at a concentration of $100 \mu \mathrm{M}$.

\section{Results and Discussion}

Schiff base ligands $\mathbf{L} \mathbf{1}$ and $\mathbf{L} \mathbf{2}$ were synthesized according to already reported synthetic routes which involved the reaction of equimolar amounts of aniline with either 2-acetylpyridine or 2-pyridinecarboxaldehyde ${ }^{37}$ For both $\mathbf{L 1}$ and $\mathbf{L 2}$ the reactions were carried out in toluene and at a temperature of $120^{\circ} \mathrm{C}$ to ensure that toluene boils to promote evaporation of any water formed from the condensation process. The synthetic scheme for compound $\mathbf{L} \mathbf{1}$ is shown in

\section{Figure 15.}
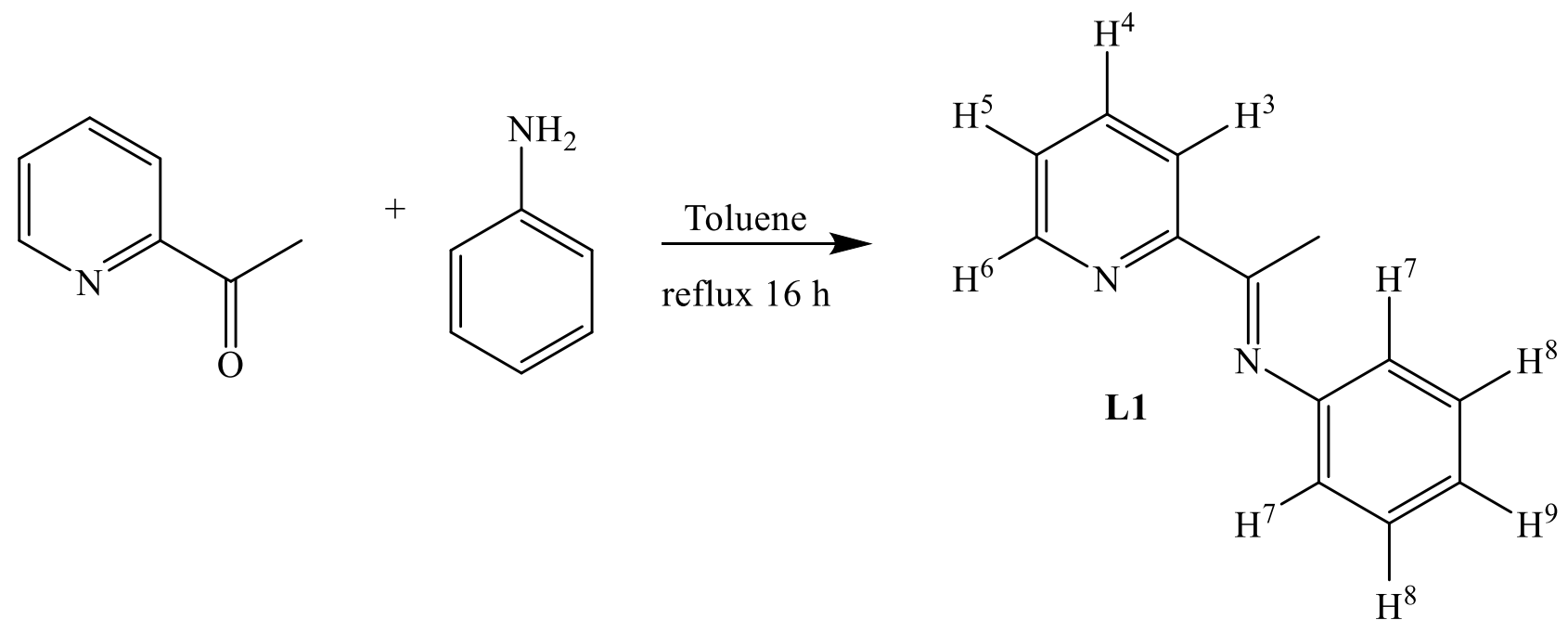

Figure 15. Reaction scheme for Schiff base L1.

In the ${ }^{1} \mathrm{H}$ NMR spectrum, of $\mathbf{L} 1$ (Figure 16) the sixth hydrogen on the pyridine (Py) ring, Py- $\mathrm{H}^{6}$ appears as a doublet downfield at chemical shift $8.59 \mathrm{ppm}$. The hydrogen at position 5 on the pyridine ring, and the two hydrogens labeled $\mathrm{H}^{8}$ on the benzene ring appear as overlapping 
peaks at $7.30 \mathrm{ppm}$ Py- $\mathrm{H}^{5}$. Next, a triplet at the chemical shift $7.71 \mathrm{ppm}$ is assigned to the hydrogen on position $4, \mathrm{Py}-\mathrm{H}^{4}$ of the pyridine ring. Another doublet corresponding to the final hydrogen on position 3, Py- $\mathrm{H}^{3}$ of the pyridine ring, also appears at $8.20 \mathrm{ppm}$. Lastly, a multiplet at $7.07 \mathrm{ppm}$ is assigned to the final hydrogen $\mathrm{Ph}-\mathrm{H}^{9}$ of the conjugated aniline moiety. The three hydrogens on the methyl group bonded to the iminic carbon also appear upfield at $2.67 \mathrm{ppm}$ as a singlet. The ESI-HRMS of the compound produced a molecular ion peak at m/z of 197.1079 which was consistent with the calculated molecular mass. ESI-HRMS spectrum of the compound is presented in APPENDIX A1.

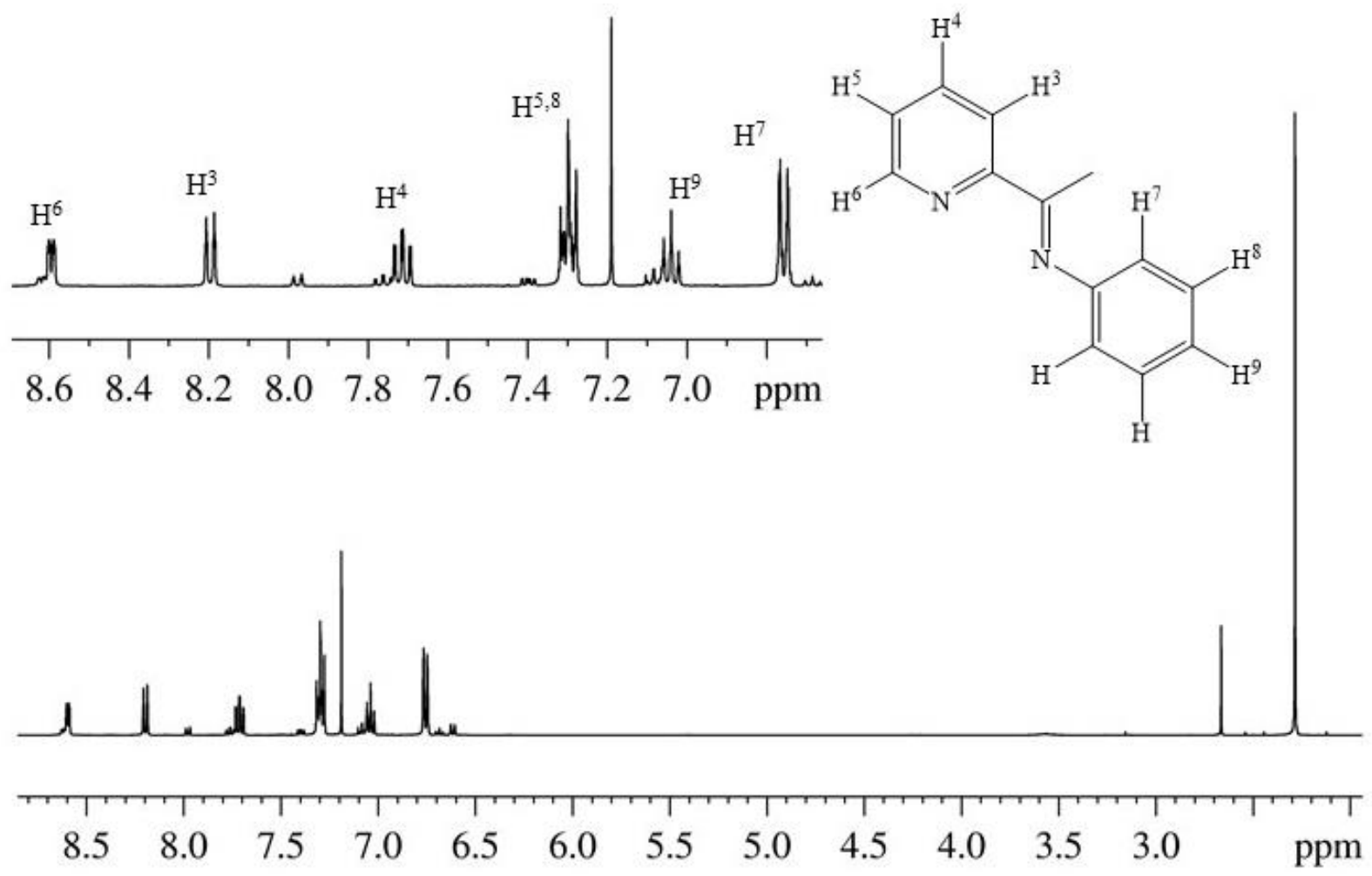

Figure 16. The ${ }^{1} \mathrm{H}$ NMR Spectrum of Schiff base $\mathbf{L 1}$ in $\mathrm{CDCl}_{3}$

L2 was also synthesized using equimolar amounts of 2-pyridinecarboxaldehyde using toluene as the solvent. Similar to $\mathbf{L} \mathbf{1}$ the reaction was also carried out at a temperature of $120^{\circ} \mathrm{C}$ to ensure 
effective reaction of the starting materials as well as avoid any possible decomposition by the formation of water by-product. The solvent was then removed to yield a brown liquid. The synthetic scheme of $\mathbf{L} 2$ is shown in Figure 17.<smiles>O=Cc1ccccn1</smiles><smiles>Nc1ccccc1</smiles><smiles>[1H]c1ccc([2H])nc1/C=N/c1ccccc1</smiles>

Figure 17. Reaction scheme for Schiff base L2.

Similar to L1, the ${ }^{1} \mathrm{H}$ NMR spectrum of $\mathbf{L 2}$ in Figure $\mathbf{1 7}$ also showed peaks spanning from $6.80 \mathrm{ppm}$ to $8.20 \mathrm{ppm}$ due to the four hydrogens on the pyridine ring and the three different hydrogen environments of the benzene ring. The major difference between the spectrum of $\mathbf{L} \mathbf{2}$ and $\mathbf{L} \mathbf{1}$ is the hydrogen $\left(\mathrm{H}^{10}\right)$ on the iminic carbon showing as singlet at 8.15 ppm replacing the methyl hydrogen signal at $2.67 \mathrm{ppm}$ seen for $\mathbf{L 1}$. 


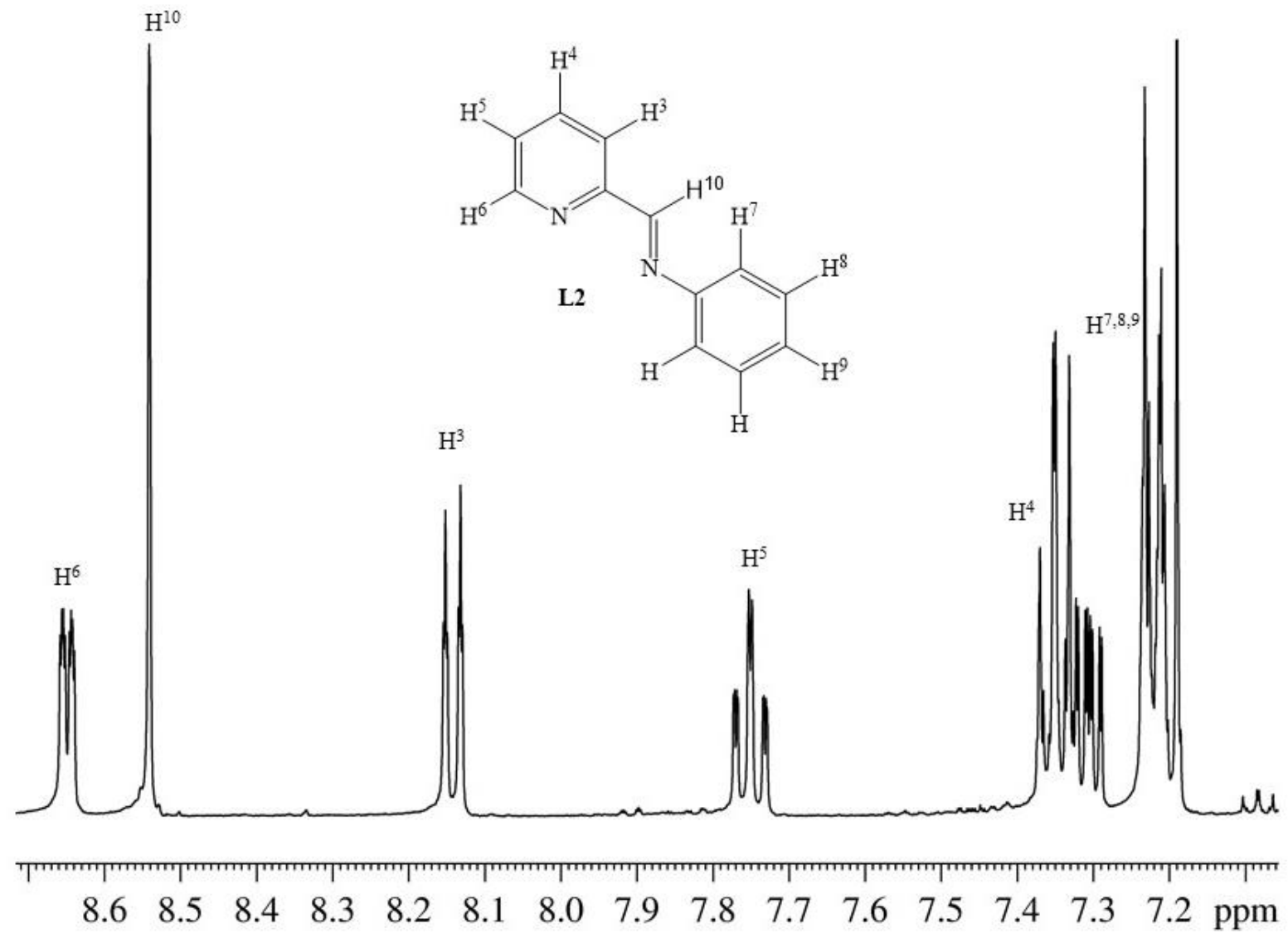

Figure 18. The ${ }^{1} \mathrm{H}$ NMR spectrum of $\mathbf{L} 2$ in $\mathrm{CDCl}_{3}$

The ESI-HRMS for L2 (APPENDIX A2)showed an intense molecular ion peak at $\mathrm{m} / \mathrm{z}$ 183.0922 which was consistent with the calculated mass-to-charge ratio of 183.0922. After successfully preparing the aniline Schiff base ligands, synthetic approaches were adopted to incorporate ferrocene into the ligands. The first example of this is $\mathbf{L 3}$ which involves the reaction between 2-acetylpyridine and 4-ferrocenylaniline. To synthesize 4-ferrocenylaniline, first, 4-nitrophenylferrocene was prepared by following an already prepared synthetic route using p-nitroaniline in a mixture of concentrated $\mathrm{HCl}, \mathrm{H}_{2} \mathrm{O}$, and aqueous $\mathrm{NaNO}_{2} \cdot{ }^{37}$ This mixture was added to a solution of hexadecyltrimethylammonium bromide (HDMBr) and ferrocene in 
ether to make 4-nitrophenylferrocene. The reaction scheme is shown in Figure 19.

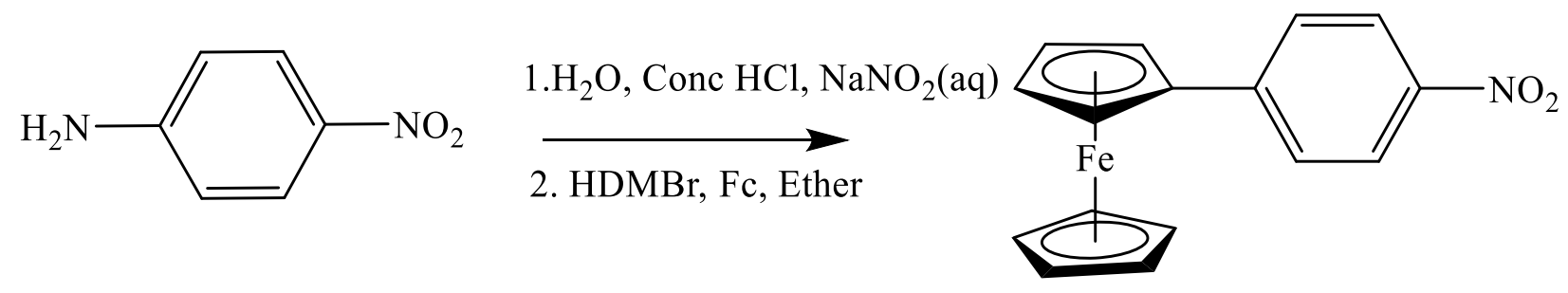

Figure 19. Reaction scheme for the synthesis of 4-nitrophenylferrocene.

In the ${ }^{1} \mathrm{H}$ NMR spectrum of the compound, shown in APPENDIX A3, resonances were found to be consistent with those reported in literature. ${ }^{31}$ The spectrum showed two doublets at $8.16 \mathrm{ppm}$ and $7.59 \mathrm{ppm}$ for the four hydrogens on the benzene ring. The three other peaks, a singlet corresponding to the unsubstituted aromatic ring was assigned a chemical shift of 4.03 $\mathrm{ppm}$. Finally, two triplets at $3.92 \mathrm{ppm}$ and $3.76 \mathrm{ppm}$ were assigned to the 4 hydrogen environments on the substituted cyclopentadienyl rings on the ferrocene.

The prepared 4-nitrophenylferrocene was subsequently reduced by tin in ethanol and concentrated $\mathrm{HCl}$ to produce 4-ferrocenylaniline (Figure 20). Successful synthesis of the compound was confirmed by measuring the ${ }^{1} \mathrm{H}$ NMR spectrum (APPENDIX A4). The spectrum appears similar to that of 4-nitrophenyl ferrocene with peaks at chemical shifts of $7.26 \mathrm{ppm}$ and $6.60 \mathrm{ppm}$ due to the two different hydrogen environments on the benzene ring along with three peaks; two triplets at $4.46 \mathrm{ppm}$ and $4.17 \mathrm{ppm}$ due to the 4 hydrogens on the substituted aromatic ring of ferrocene and one singlet of very high intensity assigned to the unsubstituted cyclopentadienyl ring also appears at $3.96 \mathrm{ppm}$. The spectrum also showed an additional broad peak of low intensity for the two hydrogens of the amine functional group which appeared at $3.59 \mathrm{ppm}$. The observed peaks correspond with the expected structure and previously reported results. ${ }^{33}$ 


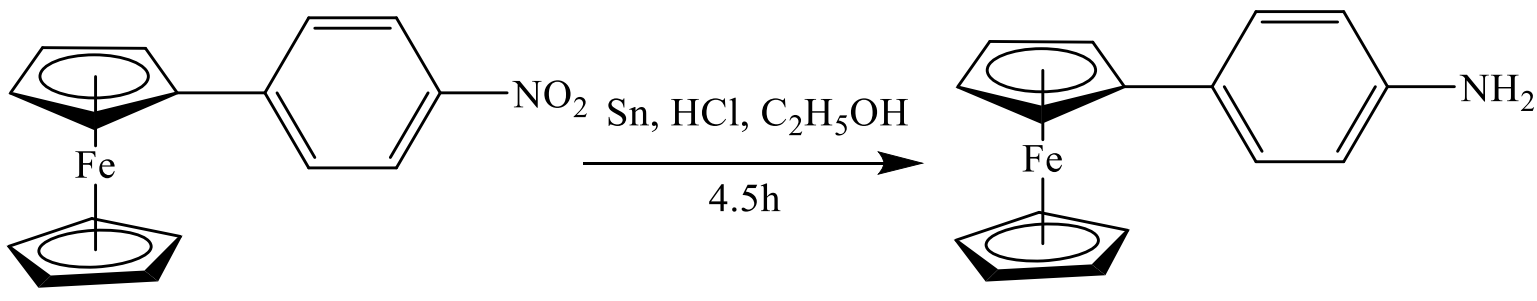

Figure 20. Reaction scheme for the synthesis of 4-ferrocenylaniline.

Compound $\mathbf{L 3}$ was then synthesized by reacting an excess amount of two acetylpyridine with the prepared 4-ferrocenylaniline in anhydrous toluene. Following an analogous procedure to that of $\mathbf{L} \mathbf{1}$ and $\mathbf{L} 2$ the solution was heated to a temperature of $120^{\circ} \mathrm{C}$ (reflux) for 6 hours yielding a dark brown precipitate as product. The synthetic scheme of L3 is shown in Figure 22.
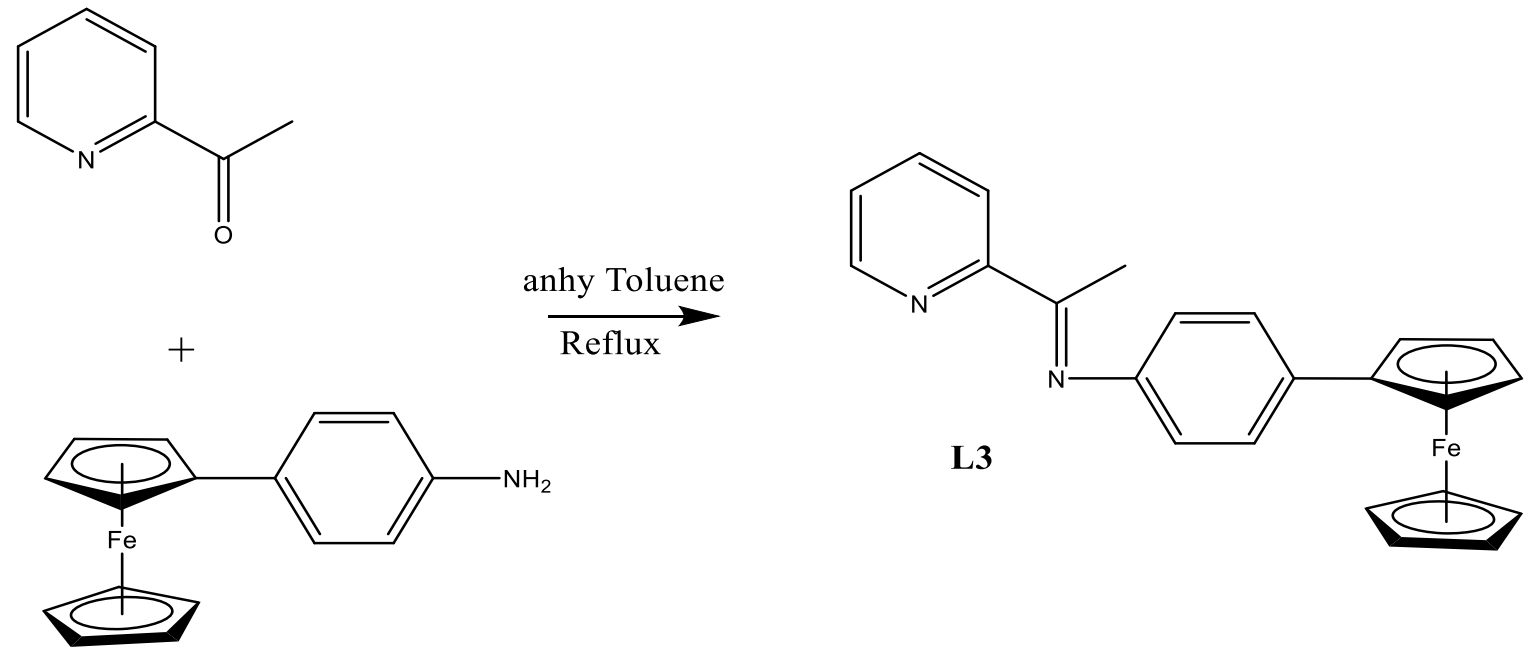

Figure 21. Synthetic scheme of L3.

L3 was characterized by ${ }^{1} \mathrm{H}$ NMR spectroscopy and the spectrum is shown in Figure 23. 


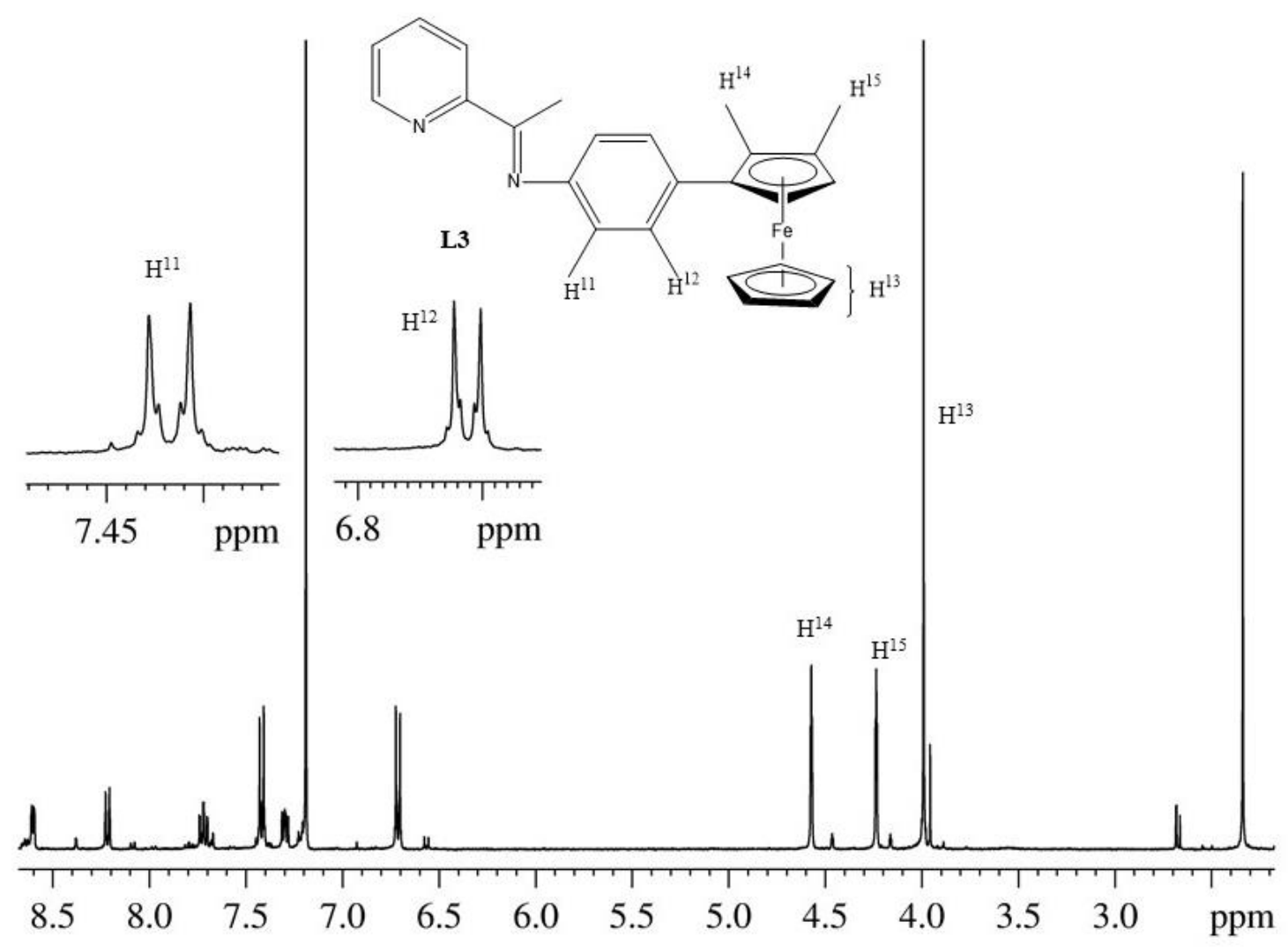

Figure 22. The ${ }^{1} \mathrm{H}$ NMR spectrum of $\mathbf{L 3}$ in $\mathrm{CDCl}_{3}$.

The spectrum of $\mathbf{L 3}$ showed the aromatic backbone spanning from the region 8.20 ppm to 6.80 ppm owing to the pyridine as seen for $\mathbf{L} \mathbf{1}$ and $\mathbf{L 2}$. In addition to these peaks, two doublets were observed at chemical shifts 7.43 and $6.71 \mathrm{ppm}$ due to the two different hydrogens $\mathrm{H}^{11}$ and $\mathrm{H}^{12}$ respectively on the phenyl group. Similar to the free ferrocenylaniline, the ferrocene group also showed three peaks; a singlet at $4.00 \mathrm{ppm}$, and two doublets appearing at chemical shifts of $4.25 \mathrm{ppm}$ and $4.50 \mathrm{ppm}$. These observed peaks are shifted downfield relative to those of the free ferrocenylaniline, supporting the formation of the desired Schiff base. The hydrogens of the methyl group also showed up at $2.35 \mathrm{ppm}$ whereas that of $\mathbf{L 1}$ appeared at $2.67 \mathrm{ppm}$. The ESI- 
HRMS (shown in APPENDIX A5) yielded a molecular ion peak of $\mathrm{m} / \mathrm{z} 381.26$ which was consistent with the calculated $\mathrm{m} / \mathrm{z}$ of 381.26 confirming the successful synthesis.

Schiff base ligand $\mathbf{L} \mathbf{4}$ was synthesized by reacting an equimolar amount of 4-

ferrocenylaniline and 2-pyridinecarboxaldehyde in dichloromethane and stirring for a period of 1 hour. The reaction scheme of $\mathbf{L 4}$ is shown in Figure 23.
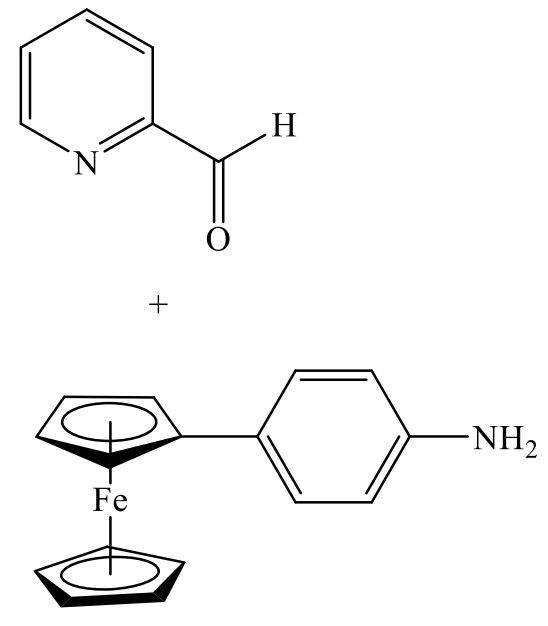

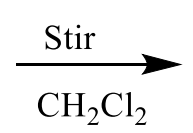

Figure. 23 Synthetic scheme of $\mathbf{L 4}$.

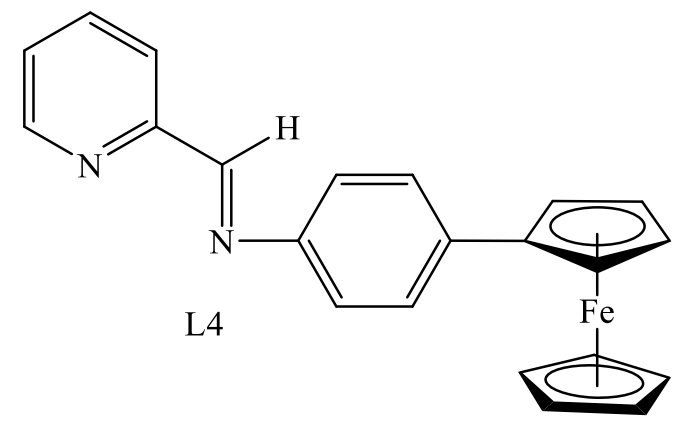

The ${ }^{1} \mathrm{H}$ NMR spectrum (Figure 25) of $\mathbf{L} \mathbf{4}$ is similar to $\mathbf{L 3}$ showing 4 peaks in the region of $8.85 \mathrm{ppm}$ to $7.45 \mathrm{ppm}$ and additional two peaks at $7.29 \mathrm{ppm}$ and $7.21 \mathrm{ppm}$ due to the two hydrogen $\mathrm{H}^{11}$ and $\mathrm{H}^{12}$ environments of the benzene ring. Compared to $\mathbf{L} \mathbf{3}$, the methyl group at $2.7 \mathrm{ppm}$ of $\mathbf{L} \mathbf{3}$ is replaced by a singlet $\mathrm{H}^{16}$ on $\mathbf{L} \mathbf{4}$ downfield at chemical shift $8.60 \mathrm{ppm}$. 

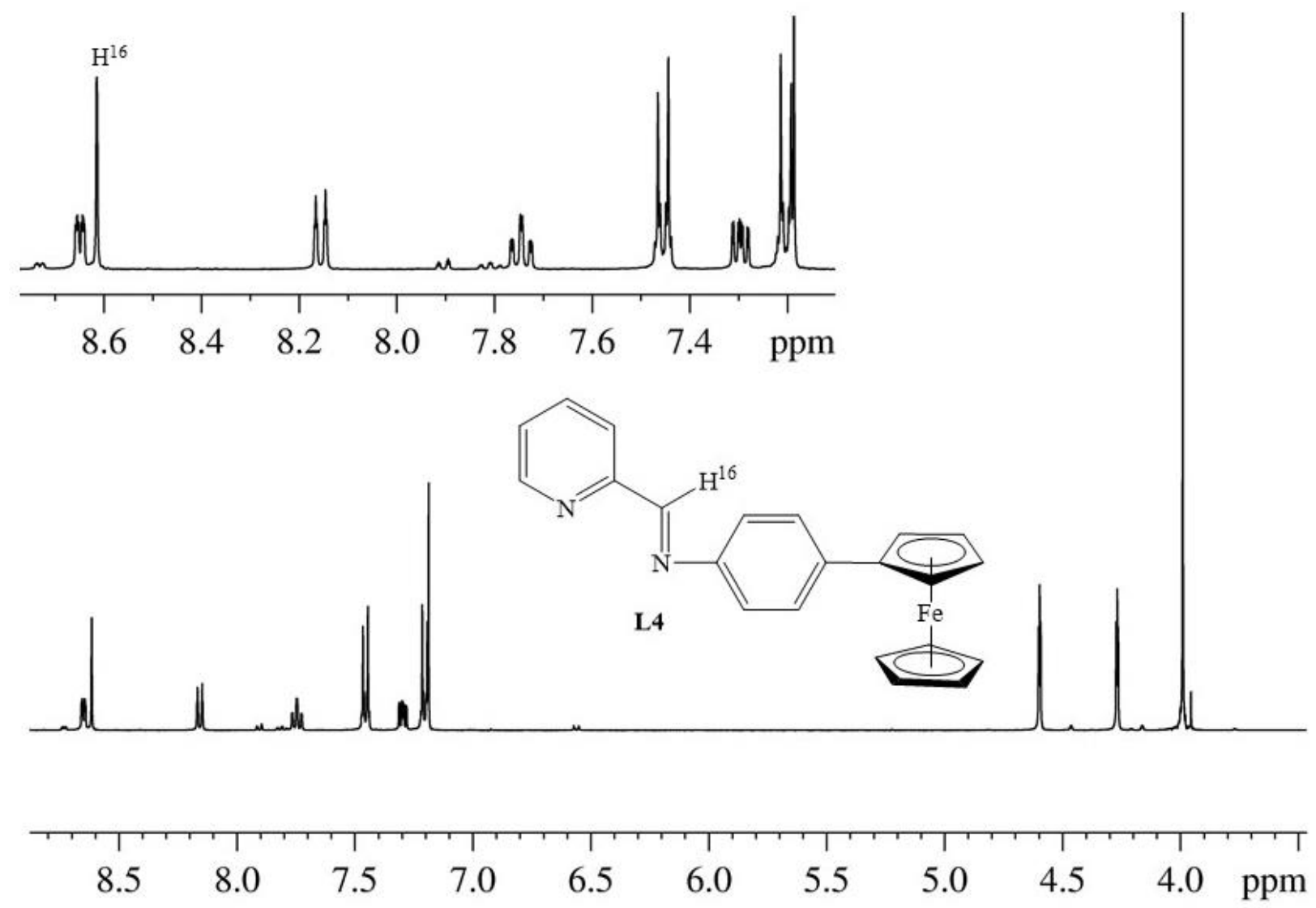

Figure 24. The ${ }^{1} \mathrm{H}$ NMR spectrum of $\mathbf{L} \mathbf{4}$ in $\mathrm{CDCl}_{3}$

To confirm a successful synthesis, ESI-HRMS (APPENDIX A6) of L4 was performed. An intense molecular ion peak at m/z 367.09 was observed which was consistent with the calculated mass-to-charge ratio of 367.09.

After successfully synthesizing the Schiff base ligands using aniline and modifying the compounds to include ferrocene, compounds L5 and L6 were synthesized by reacting 2acetylpyridine and 2-pyridinecarboxaldehyde respectively with aminoferrocene. Since aminoferrocene is very expensive we took a synthetic approach that was comprised of three steps starting with ferrocencarboxylic acid. In the first step, ferrocenoyl azide was prepared by reacting ferrocencarboxylic acid with oxalyl chloride dimethylformamide (DMF) and sodium 
azide in dichloromethane. The product was confirmed by measuring the ${ }^{1} \mathrm{H}$ NMR spectrum (APPENDIX 7). Three peaks were observed; two triplets at chemical shifts of $4.75 \mathrm{ppm}$ and 4.44 ppm were assigned to the four hydrogen on the substituted cyclopentadienyl ring and a singlet at $4.19 \mathrm{ppm}$ chemical shift were assigned to the five hydrogens on the unsubstituted cyclopentadienyl ring. The resonances observed were consistent with the spectrum reported in literature indicating a successful synthesis of the compound. ${ }^{40}$ The synthetic scheme of the compound is shown in Figure 25.
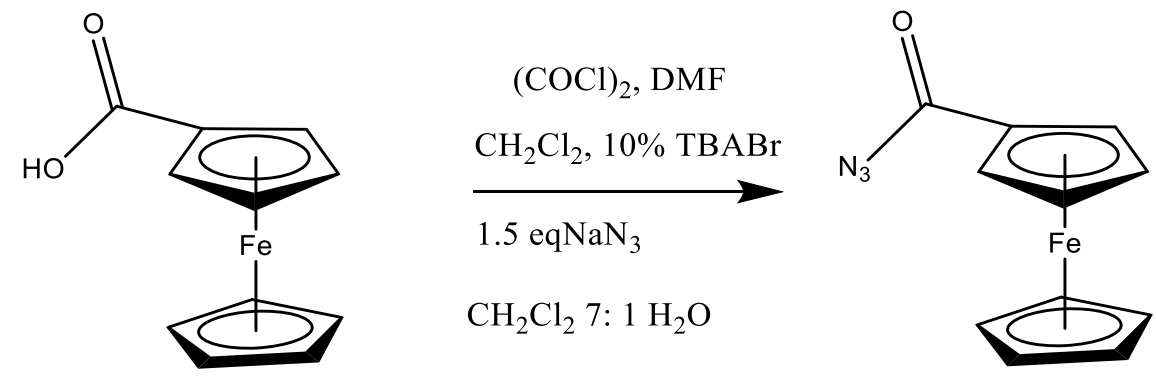

Figure 25. Synthetic scheme of ferrocenoyl azide from ferrocenecarboxylic acid.

Since azides are unstable compounds, a protecting group, 2-(trimethylsilyl)ethanol, was added to form 2-(trimethylsilyl)ethyl ferrocenylcarbamate as shown in Figure 26.
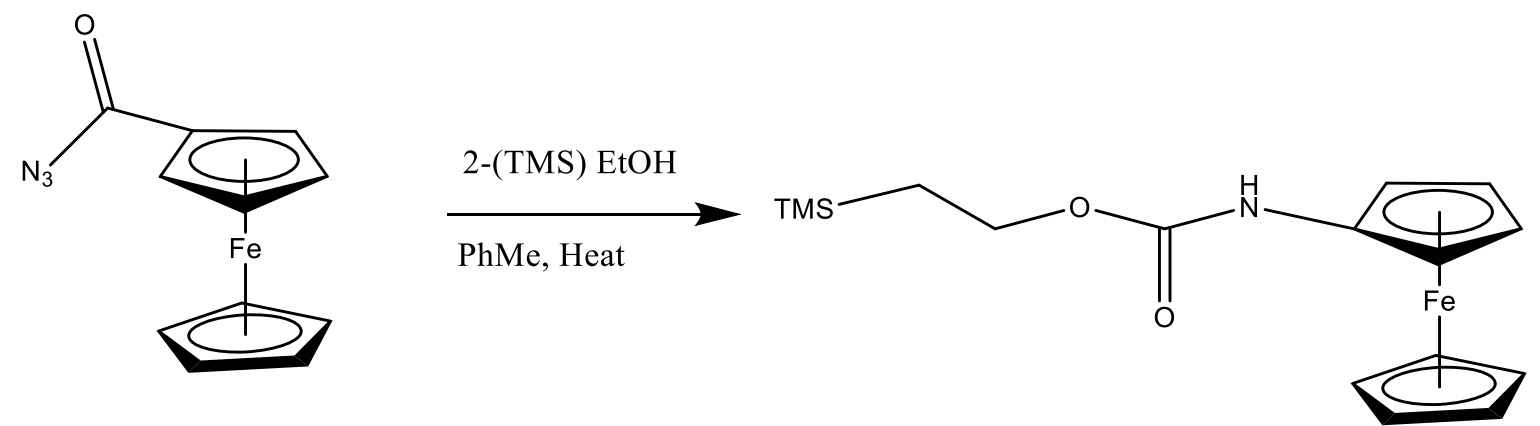

Figure 26. Synthetic scheme to prepare 2-(trimethylsilyl)ethylferrocenylcarbamate from ferrocenoyl azide. 
The ${ }^{1} \mathrm{H}$ NMR spectrum (APPENDIX A8) of the 2-

(trimethylsilyl)ethylferrocenylcarbamate showed 5 peaks spanning the entire spectra window. Beginning downfield, the peak at a chemical shift of $8.63 \mathrm{ppm}$ was assigned to the hydrogen on the carbamate functional group. Next, two doublets at 4.40 and $4.09 \mathrm{ppm}$ correspond to the substituted arene ring on the ferrocene, while the singlet at $3.86 \mathrm{ppm}$ was assigned to the unsubstituted ring. Lastly, upfield, a singlet at $0.06 \mathrm{ppm}$ was assigned to the 9 hydrogens on the trimethylsilyl (TMS) group. These resonances were consistent with that of the compound already reported in literature. ${ }^{40}$ The carbamate compound is stable and can undergo further reaction without decomposition.

The final step in the synthesis used tetrabutylammonium fluoride (TBAF) in tetrahydrofuran (THF) to deprotect the carbamate to yield the target aminoferrocene. This was achieved by refluxing the reaction mixture in THF for a period of 2 hours. The ${ }^{1} \mathrm{H}$ NMR (APPENDIX A9) of aminoferrocene was measured and resonances were observed at the ferrocenyl region. Compared to the carbamate compound, the hydrogens on the unsubstituted cyclopentadienyl was shifted downfield to $4.03 \mathrm{ppm}$ whereas the four hydrogens on the substituted arene ring appeared at $3.92 \mathrm{ppm}$ and $3.77 \mathrm{ppm}$. Additionally, a broad short peak at $2.50 \mathrm{ppm}$ due to the 2 hydrogens on amine functional group was also observed in the spectrum. The spectrum was consistent with that as reported in literature. ${ }^{40}$ The reaction scheme of aminoferrocene is shown in Figure 27. 


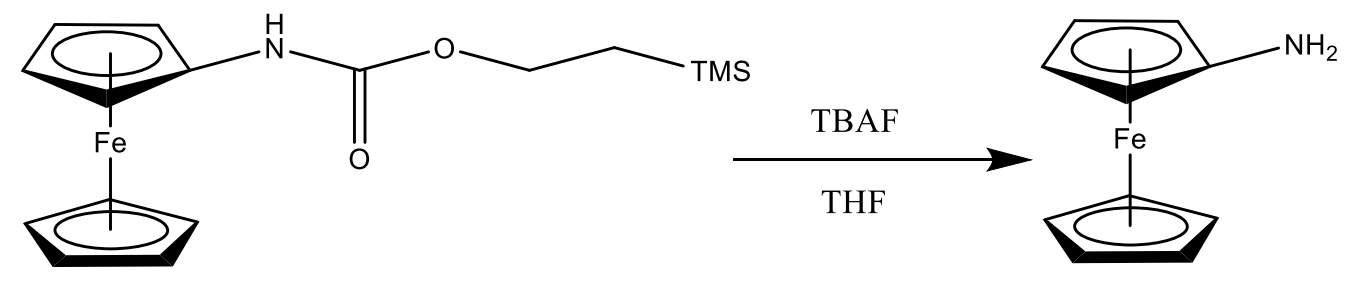

Figure 27. Synthetic scheme to prepare aminoferrocene from 2-

(trimethylsilyl)ethylferrocenylcarbamate.

Having successfully prepared aminoferrocene, compound $\mathbf{L 5}$ was then synthesized by refluxing equimolar amounts of aminoferrocene and 2-acetylpyridine in anhydrous toluene for 2 hours. The synthetic scheme of the reaction is represented in Figure 28.
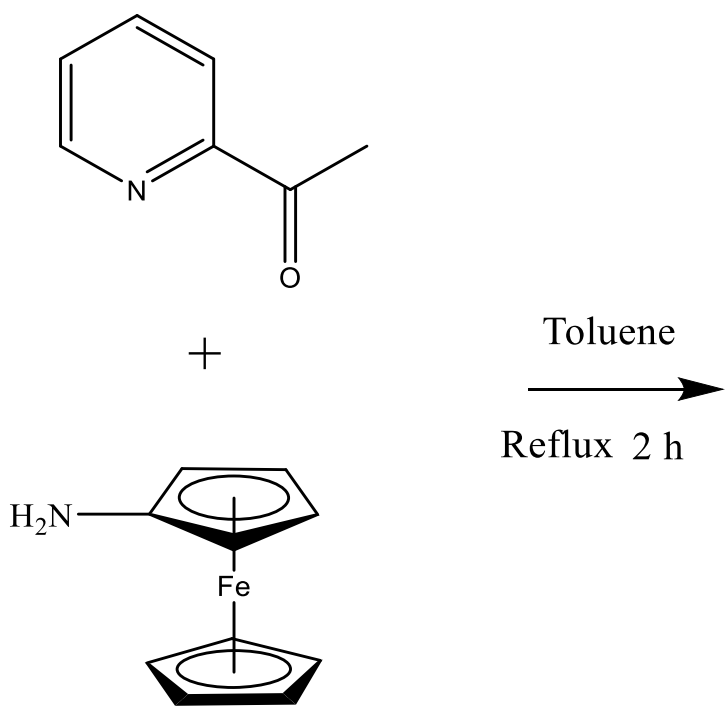

Figure 28. Synthetic scheme to prepare $\mathbf{L 5}$. 
The ${ }^{1} \mathrm{H}$ NMR spectrum (Figure 29) of the compound showed resonances within the aromatic region due to the pyridine ring which spans the region of $8.55 \mathrm{ppm}$ to $7.25 \mathrm{ppm}$ similar to compound L1. However, the multiplet observed at chemical $7.03 \mathrm{ppm}$ assigned to the conjugated benzene ring in compound $\mathbf{L} \mathbf{1}$ is replaced by two doublets at chemical shifts 4.25 ppm and $4.45 \mathrm{ppm}$ due to the substituted aromatic ring of ferrocene and a singlet of high intensity at $4.00 \mathrm{ppm}$ assigned to the unsubstituted ring. These chemical shifts of the ferrocene backbone are consistent with those of compounds L3 and L4. Similar to compounds L1 and L3 where the hydrogens on the methyl group appears as a singlet at chemical shifts $2.35 \mathrm{ppm}$ and $2.65 \mathrm{ppm}$ respectively, the hydrogens on the methyl group $\left(\mathrm{H}^{18}\right)$ of $\mathbf{L 5}$ also appeared as a singlet at $2.40 \mathrm{ppm}$. The molecular ion peak (APPENDIX A10) $\mathrm{m} / \mathrm{z} 305.07$ did not vary with that calculated confirming a successful synthesis of the Schiff base compound.

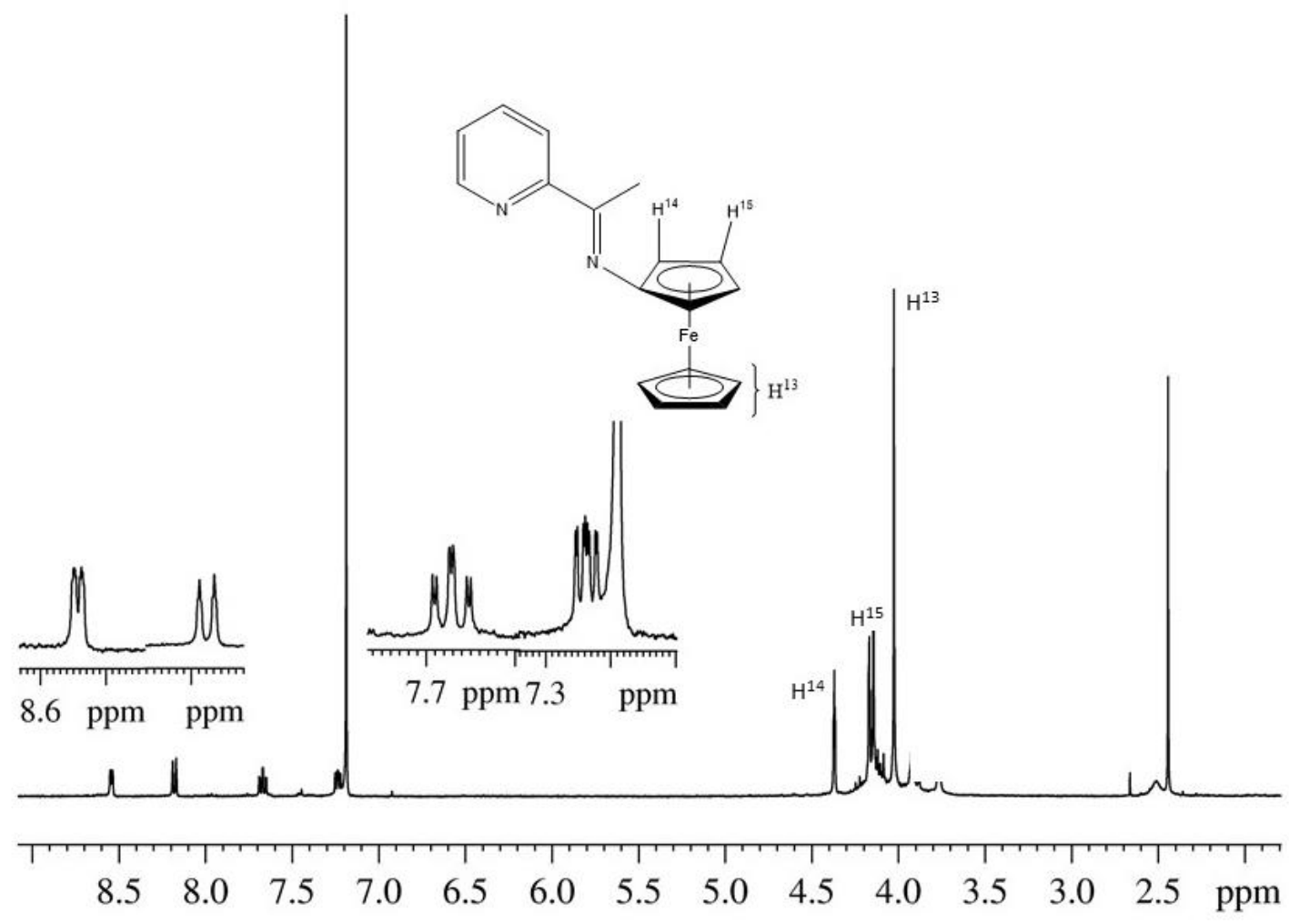

Figure 29. The ${ }^{1} \mathrm{H}$ NMR spectrum of Schiff base $\mathbf{L 5}$ in $\mathrm{CDCl}_{3}$. 
Similar to compound L4, L6 was synthesized by stirring a mixture aminoferrocene and 2-pyridinecarboxaldehyde dichloromethane at room temperature for 1 hour (Figure 31). After mixing the solvent was removed completely to yield a dark violet precipitate.

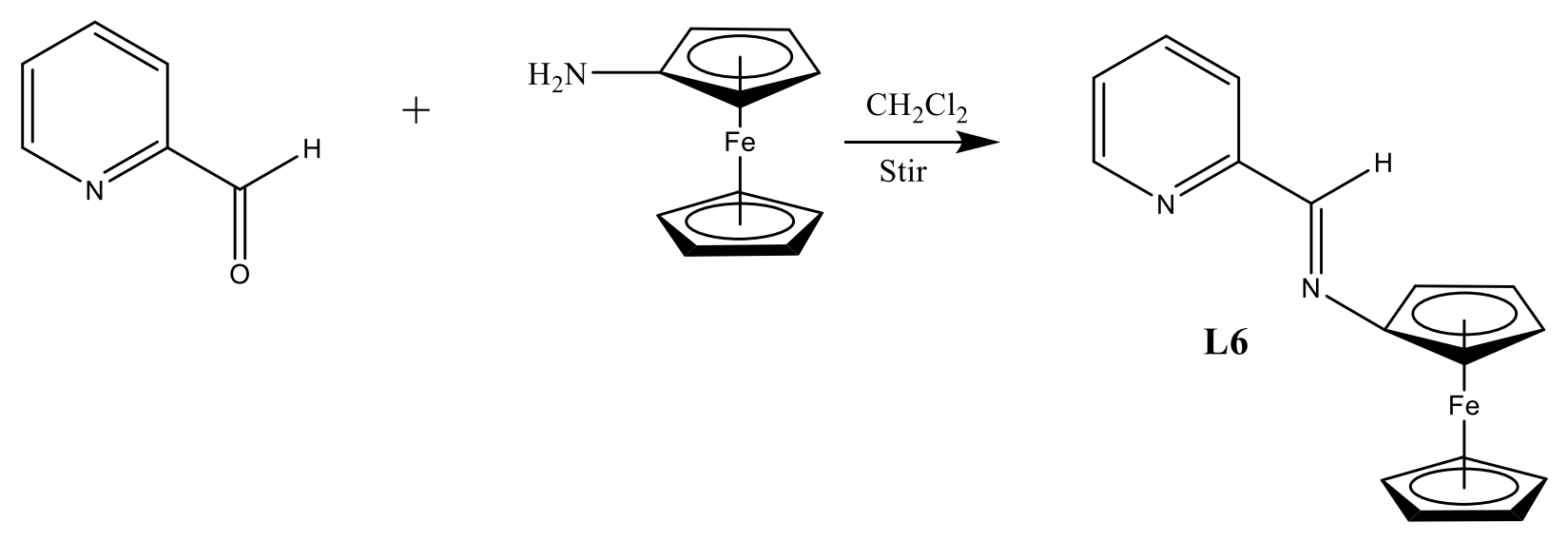

Figure 30. Synthetic scheme of $\mathbf{L 6}$.

The ${ }^{1} \mathrm{H}$ NMR spectrum of $\mathbf{L 6}$ is similar to $\mathbf{L 5}$. The major difference, similar to the previous Schiff base, lies in the resonances due to the methyl of 2-acetylpyridine and the hydrogen of the 2-pyridinecarboxaldehyde. The methyl group which appears at a chemical shift of $2.40 \mathrm{ppm}$ is replaced by the hydrogen, $\mathrm{H}^{17}$ which appears at $8.68 \mathrm{ppm}$. ESI-HRMS (APPENDIX A11) data yielded a molecular ion peak of m/z 291.06 which matches that obtained from the calculated mass-to-charge ratio of 291.05 for $\mathbf{L 6 .}$ 


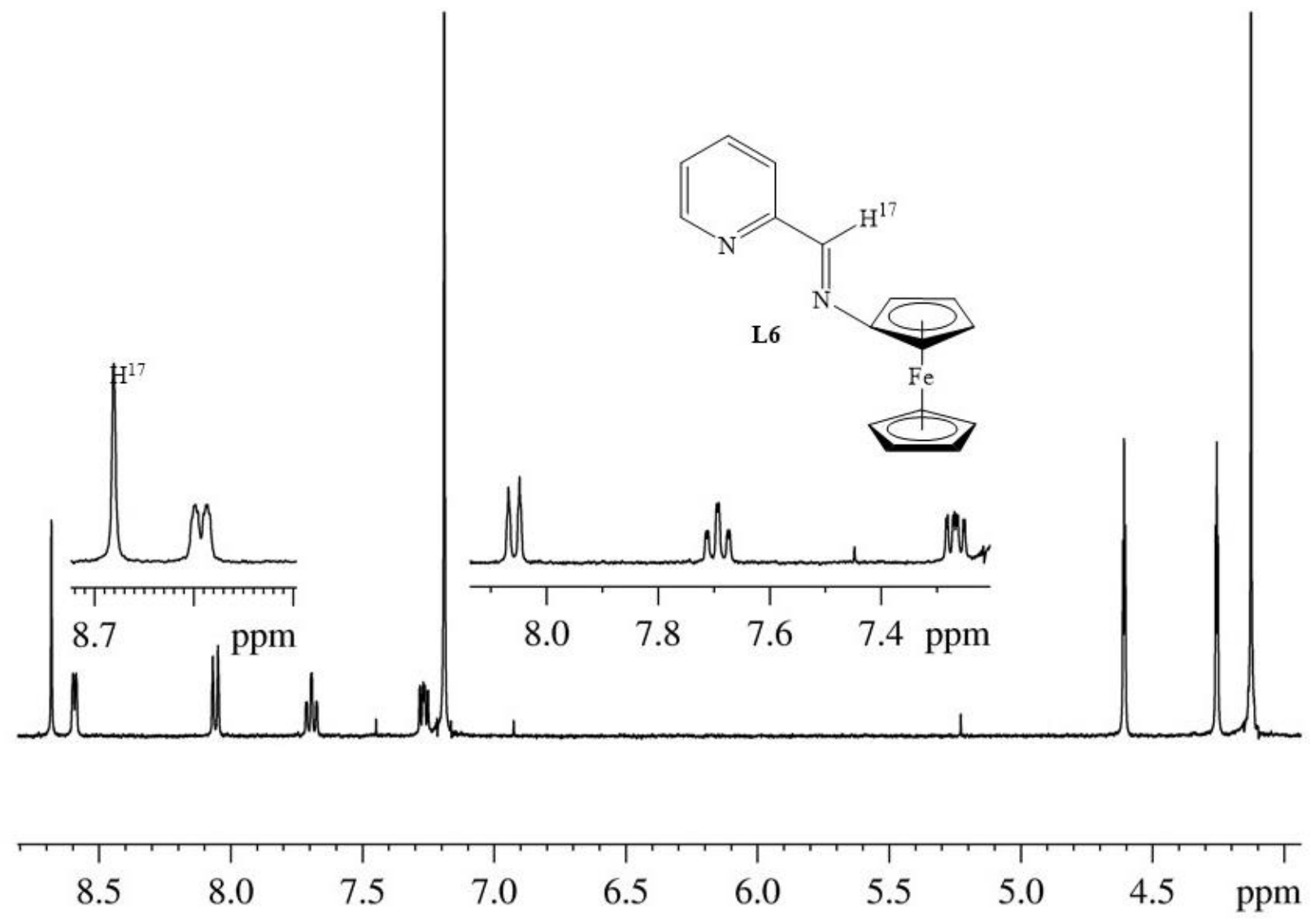

Figure 31. ${ }^{1} \mathrm{H}$ NMR spectrum of $\mathbf{L 6}$.

To check the stability of the Schiff base ligands in aqueous PBS and 50\% DMSO at 37 ${ }^{\circ} \mathrm{C}$ for 2 hours, the UV-vis spectra of the six Schiff bases were collected. The spectrum of $\mathbf{L} \mathbf{1}$ is shown in Figure 32 and those of L3, L5, and L6 are shown in APPENDIX A12. 


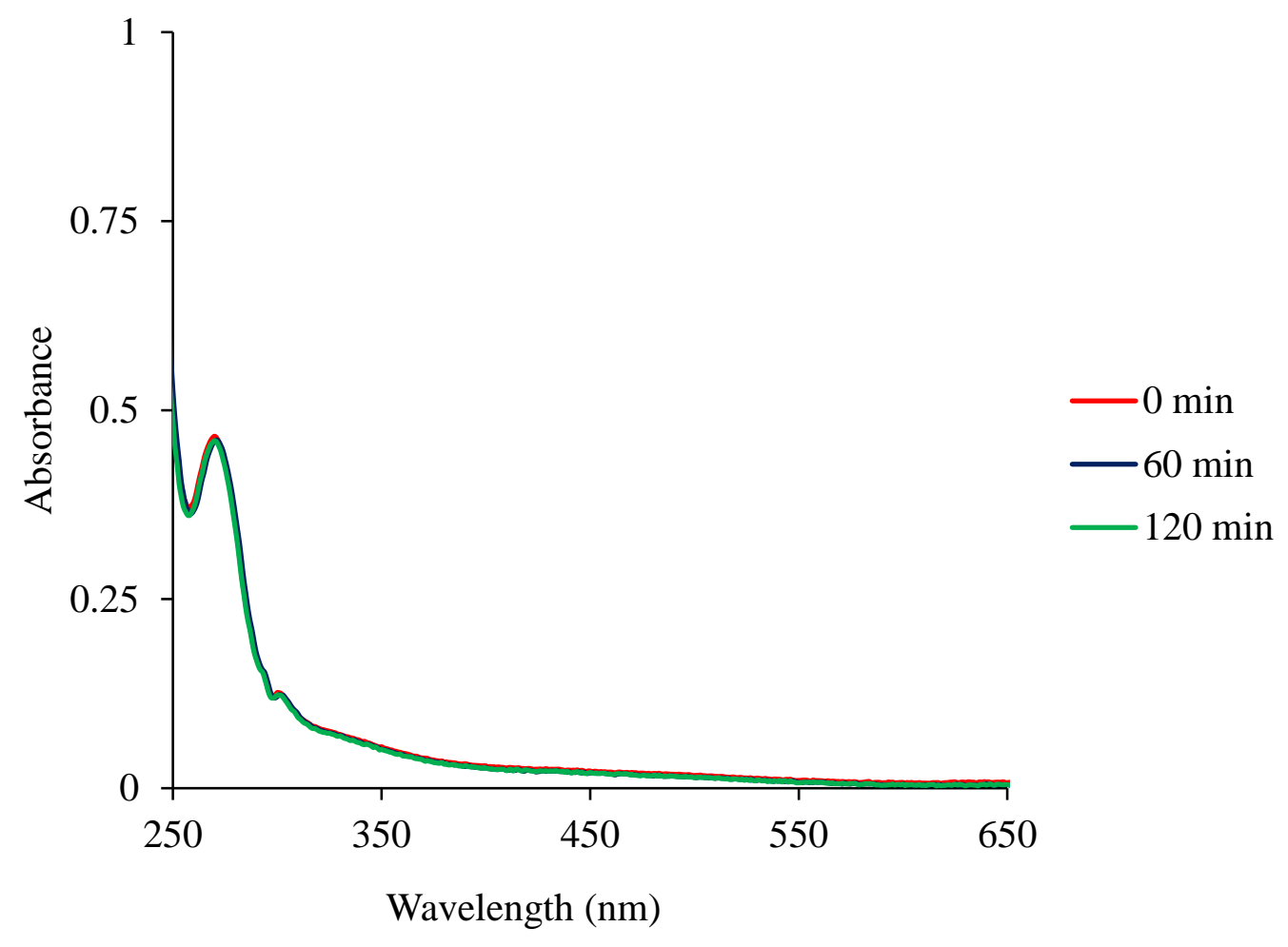

Figure 32. UV-vis spectrum of $\mathbf{L} 1$ in $50 \%$ DMSO and PBS(aq) at $\mathrm{pH}$ of 7.4 and a temperature of $37^{\circ} \mathrm{C}$.

The UV-vis spectrum of $\mathbf{L} \mathbf{1}$ did not vary over a period of 2 hours. Similarly, the spectra collected for $\mathbf{L 3}, \mathbf{L 5}$, and $\mathbf{L 6}$ also did not change over the same period of measurement. This suggests that these ligands are stable under the given set of conditions. However, the UV-vis spectrum of compounds $\mathbf{L} \mathbf{2}$ and $\mathbf{L} \mathbf{4}$ continuously varied over the same 2-hour measurement period. This indicates that $\mathbf{L} \mathbf{2}$ and $\mathbf{L} \mathbf{4}$ are not stable under the 2-hour period(Figure 34). 


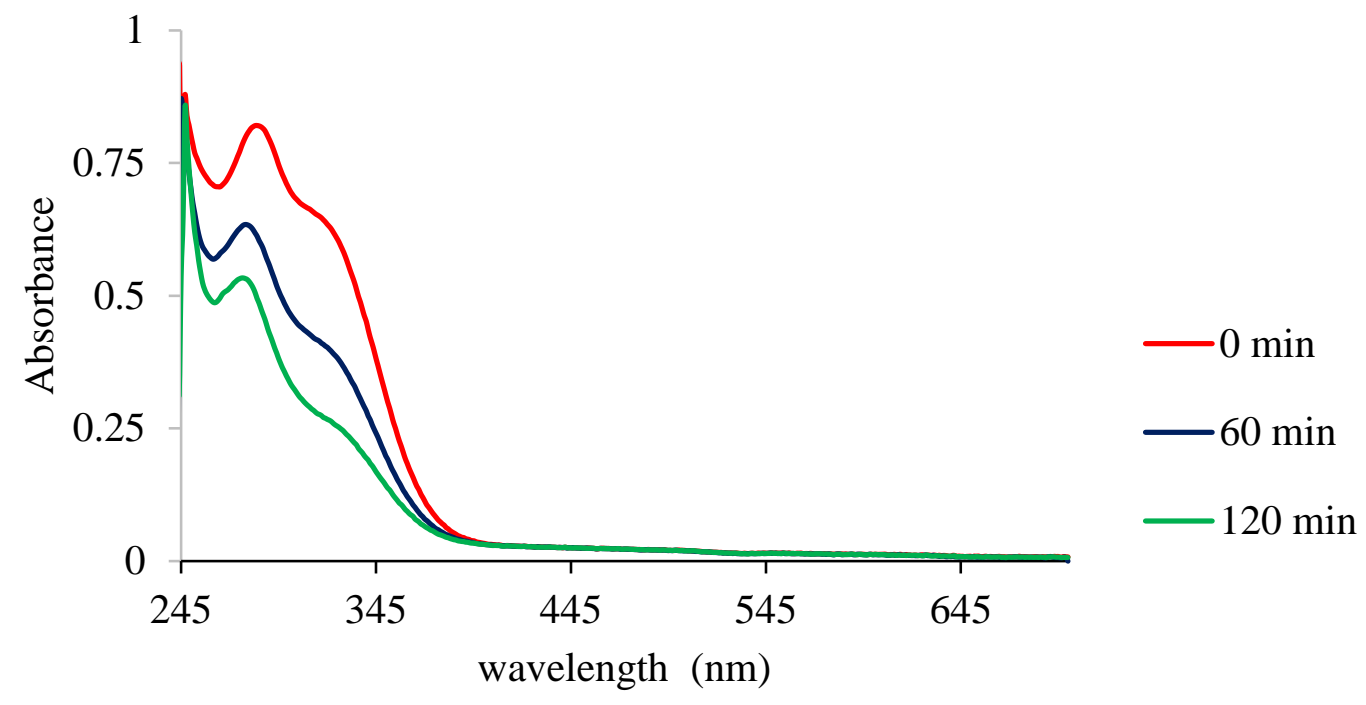

Figure 33. UV-vis spectrum of $\mathbf{L} 2$ in $50 \%$ DMSO and PBS(aq) at $\mathrm{pH}$ of 7.4 and a temperature of $37{ }^{\circ} \mathrm{C}$.

The spectrum of $\mathbf{L 4}$ (Figure 35) also showed variation in absorbance over the 2-hour period. The spectrum showed an isosbestic point at a wavelength of $290 \mathrm{~nm}$ where the absorbance of the compound remained constant. This indicates the formation of a new compound directly from the complex in the buffer solution. ${ }^{1} \mathrm{H}$ NMR spectrum of the ligand $\mathbf{L} \mathbf{2}$ under the same set of conditions will be run to confirm the observations made. 


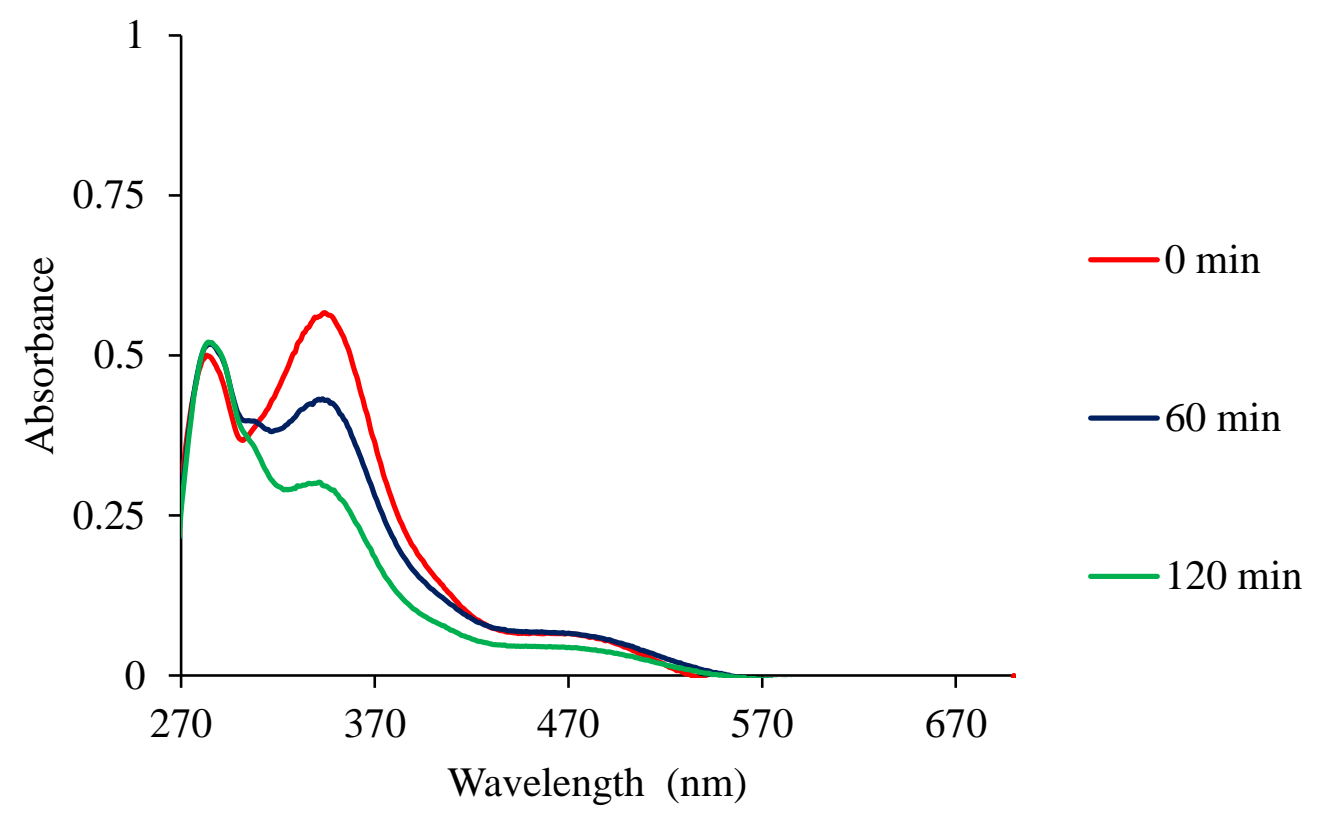

Figure 34. UV-vis spectrum of $\mathbf{L} 4$ in $50 \%$ DMSO and PBS(aq) at $\mathrm{pH}$ of 7.4 and a temperature of $37^{\circ} \mathrm{C}$.

\section{Conclusion}

Six Schiff base ligands were successfully synthesized by reaction of each of 2acetylpyridine and 2-pyridinecarboxaldehyde with aniline, 4-ferrocenylaniline and aminoferrocene. The Schiff bases were characterized using ${ }^{1} \mathrm{H}$ NMR and ESI-HRMS and their aqueous stability was assessed using UV-vis Spectroscopy. These compounds were subsequently used to synthesize new $\mathrm{Ru}$ (II) arene complexes, the results of which will be discussed in the following chapter. 


\section{CHAPTER III: SYNTHESES OF RUTHENIUM(II) ARENE COMPLEXES}

\section{CONTAINING SCHIFF BASE LIGANDS}

\section{Ruthenium(II) Arene Schiff Base (RAS) Complexes}

Due to the pharmaceutical significance of Schiff bases, recent design of $\mathrm{Ru}(\mathrm{II})$ anticancer compounds take into consideration the use of Schiff bases to improve the efficacy of the compounds. Chow et al. evaluated the anticancer activity of three Ru(II) arene Schiff base compounds (Figure 35). ${ }^{42}$ In this study, cisplatin was found to be inactive against MCF breast cancer cell with $\mathrm{IC}_{50}$ greater than $50 \mu \mathrm{M}$. However, all the three compounds a, b, and c were found to be more active with $\mathrm{IC}_{50}$ values of $2.93 \mu \mathrm{M}, 6.47 \mu \mathrm{M}$ and $13.17 \mu \mathrm{M}$ respectively.

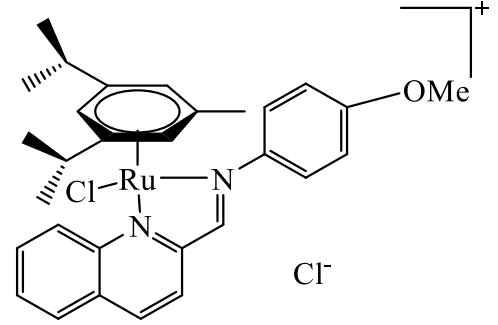

a

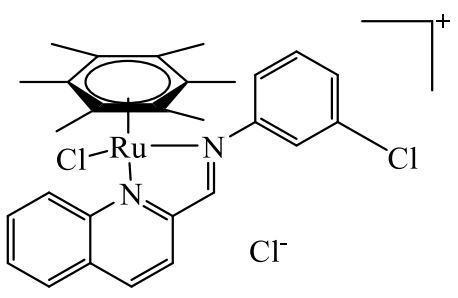

$\mathrm{b}$

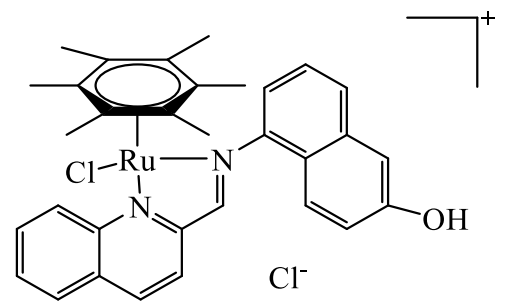

c

Figure 35. Examples of ruthenium(II) Schiff base complexes.

The Schiff base ligands $\mathbf{L 1}$ to $\mathbf{L 6}$ were then reacted with the $\mathrm{Ru}(\mathrm{II})$ dimer starting material to produce new $\mathrm{Ru}(\mathrm{II})$ anticancer compounds (Figure 36). 

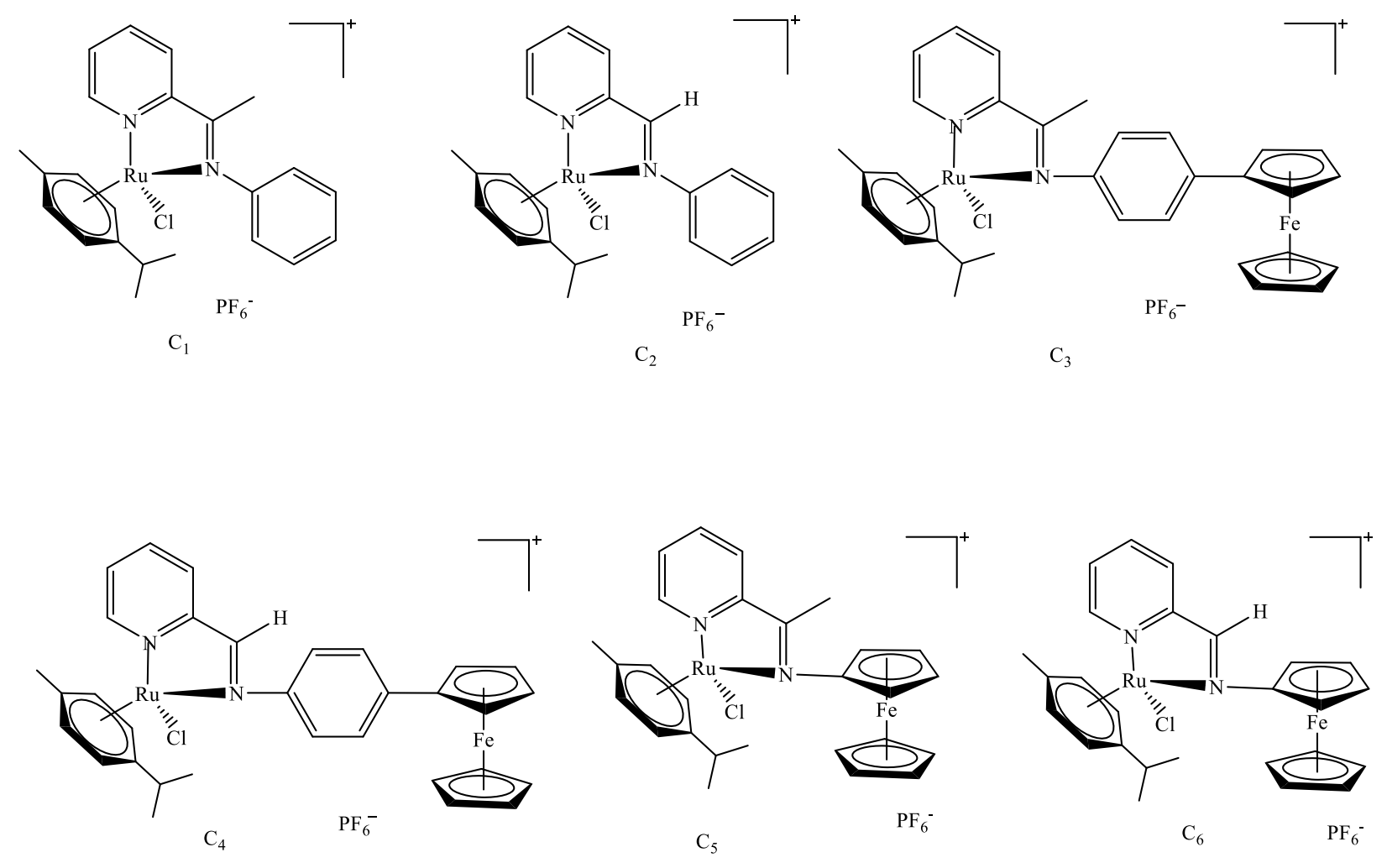

Figure 36. Ruthenium(II) arene Schiff base target compounds.

\section{Experimental}

\section{General Materials and Methods}

The reagents utilized were purchased from Fisher Scientific, Sigma Aldrich, Cambridge Isotope Laboratories, or Oakwood Chemical. All chemicals acquired were used as received. The ${ }^{1} \mathrm{H}$ NMR of the complexes were all measured with 16 scans, and field centered at $6 \mathrm{ppm}$, a sweep width of $20 \mathrm{ppm}$, and a relaxation time of 1 second. Elemental Analysis (EA) data were collected by the University of Illinois Urbana-Champaign School of Chemical Sciences Microanalysis Laboratory where acceptable values are within \pm 0.4 weight $\%$ of the theoretical values for each element $(\mathrm{C}, \mathrm{H}, \mathrm{N})$.

\section{Instrumentation}

The ${ }^{1} \mathrm{H}$ NMR spectrum of the ruthenium(II) arene Schiff base compounds were collected using a Bruker Avance III $400 \mathrm{MHz}$ NMR spectrometer with either $\mathrm{CDCl}_{3}$ or DMSO- $\mathrm{d}_{6}$ as the 
solvent. The ${ }^{1} \mathrm{H}$ NMR spectra of the compounds were processed using the Topspin 2.1 software. The UV-vis spectra of the Ru(II) complexes were collected using an Evolution 260 Bio Spectrophotometer equipped with a single cell Peltier system and a Haake DC 10 pump. The software on which the experiments were run was the Thermo INSIGHT software. Synthesis of Ru(II) starting material

$\mathrm{RuCl}_{3} \cdot 3 \mathrm{H}_{2} \mathrm{O}(1.01 \mathrm{~g}, 4.90 \mathrm{mmol})$ was dissolved in ethanol $(50 \mathrm{~mL})$ and $\alpha$-phellandrene (10 mL, $30.52 \mathrm{mmol}$ ) was added. The mixture was heated at reflux for 4 hours and then cooled to room temperature. The solvent was evaporated to half volume and the mixture kept in the freezer overnight and filtered to produce an orange brown solid. Yield: $75 \%(1.035 \mathrm{~g}){ }^{1} \mathrm{H}$ NMR $\delta=(400 \mathrm{MHz}: 5.95(\mathrm{~d}, 2 \mathrm{H}, \mathrm{J}=6.79 \mathrm{~Hz}) 5.83(\mathrm{~d}, 2 \mathrm{H}, \mathrm{J}=5.86 \mathrm{~Hz}), 5.60(\mathrm{~d}, 2 \mathrm{H}, \mathrm{J}=5.94 \mathrm{~Hz})$, $2.85(\mathrm{sep}, 2 \mathrm{H}, \mathrm{J}=6.54 \mathrm{~Hz}), 2.22(\mathrm{~s}, 3 \mathrm{H}), 2.18(\mathrm{~s}, 3 \mathrm{H}), 1.31(\mathrm{t}, 12 \mathrm{H}, \mathrm{J}=7.09 \mathrm{~Hz})$. Synthesis of Compound $C_{1}$

The prepared $\mathrm{Ru}(\mathrm{II})$ arene dimer $(0.22 \mathrm{~g}, 0.37 \mathrm{mmol})$ and Schiff base ligand $\mathbf{L 1}(0.15 \mathrm{~g}$, $0.75 \mathrm{mmol}$ ) were put into a $25 \mathrm{~mL}$ round bottom flask. High performance liquid chromatography (HPLC) grade methanol ( $8 \mathrm{~mL})$ was then added. The reaction was then stirred at room temperature for 4 hours. Ammonium hexafluorophosphate $(0.29 \mathrm{~g}, 1.87 \mathrm{mmol})$ was then added directly and the resulting mixture was stirred for 10 minutes, then the reaction mixture was kept in the fridge $\left(4^{\circ} \mathrm{C}\right)$ overnight and solid precipitates were formed. The product was then filtered off and dried to yield the product as a bright orange solid. Yield: $53 \%(0.060 \mathrm{~g}){ }^{1} \mathrm{H}$ NMR $\delta=$ $\left(400 \mathrm{MHz}, \mathrm{CDCl}_{3}\right): 9.35\left(\mathrm{~d}, 1 \mathrm{H}, \mathrm{J}=5.67 \mathrm{~Hz}, \mathrm{Py}-\mathrm{H}^{6}\right), 8.12\left(\mathrm{td}, 1 \mathrm{H},{ }^{1} \mathrm{~J}=6.46,{ }^{2} \mathrm{~J}=1.58 \mathrm{Py}-\mathrm{H}^{5}\right)$, $8.04\left(\mathrm{~d}, 1 \mathrm{H}, \mathrm{J}=7.89 \mathrm{~Hz}, \mathrm{Py}-\mathrm{H}^{3}\right), 7.76\left(\mathrm{dd}, 1 \mathrm{H},{ }^{1} \mathrm{~J}=4.12,{ }^{2} \mathrm{~J}=1.41, \mathrm{Py}-\mathrm{H}^{4}\right) 7.48\left(\mathrm{t}, 1 \mathrm{H}, \mathrm{Ph}-\mathrm{H}^{8}\right)$, $5.50\left(\mathrm{t}, \mathrm{H}, \mathrm{Ph}-\mathrm{H}^{7}\right), 5.48\left(\mathrm{~d}, 2 \mathrm{H}, \mathrm{p}-\mathrm{Cym}-\mathrm{H}^{12}\right), 5.27\left(\mathrm{dd}, 2 \mathrm{H}, \mathrm{J}=6.14 \mathrm{~Hz}, \mathrm{p}-\mathrm{Cym}-\mathrm{H}^{13}\right), 2.7$ (sep, $\left.1 \mathrm{H}, \mathrm{J}=7.09, \mathrm{CH}\left(\mathrm{CH}_{3}\right)_{2}\right), 2.50\left(\mathrm{~s}, 3 \mathrm{H}, \mathrm{p}-\mathrm{Cym}_{-} \mathrm{CH}_{3}\right), 2.12\left(\mathrm{~s}, 3 \mathrm{H}, \mathrm{CH}_{3} \mathrm{C}=\mathrm{N}\right), 1.12(\mathrm{~d}, 3 \mathrm{H}, \mathrm{J}=6.82$ $\mathrm{CH}\left(\mathrm{CH}_{3}\right), 1.03$ (d. 3H, J = $6.99 \mathrm{CH}\left(\mathrm{CH}_{3}\right)$. 


\section{Synthesis of Compound $C_{2}$}

The prepared $\mathrm{Ru}(\mathrm{II})$ arene dimer $(0.22 \mathrm{~g}, 0.36 \mathrm{mmol})$ and Schiff base ligand $\mathbf{L} 2(0.13 \mathrm{~g}$, $0.72 \mathrm{mmol})$ were put into a $25 \mathrm{~mL}$ round bottom flask. HPLC grade methanol $(8 \mathrm{~mL})$ was then added. The reaction was then stirred at room temperature for 4 hours. Ammonium hexafluorophosphate $(0.29 \mathrm{~g}, 1.80 \mathrm{mmol})$ was then added directly and the resulting mixture was stirred for 10 minutes, then the reaction mixture was kept in the fridge overnight and solid precipitates were formed. The product was then filtered off and dried to yield the product as a dark purple solid. Yield: $83 \%(0.18 \mathrm{~g}){ }^{1} \mathrm{H}$ NMR $\delta=\left(400 \mathrm{MHz}, \mathrm{CDCl}_{3}\right): 9.34(\mathrm{~d}, 1 \mathrm{H}, \mathrm{J}=6.19$ $\left.\mathrm{Hz}, \mathrm{Py}-\mathrm{H}^{6}\right), 8.44(\mathrm{~s}, 1 \mathrm{H}, \mathrm{CH}=\mathrm{N}), 8.10\left(\mathrm{t}, 1 \mathrm{H}, \mathrm{J}=6.24 \mathrm{Py}-\mathrm{H}^{5}\right), 7.83\left(\mathrm{~d}, 1 \mathrm{H}, \mathrm{J}=7.08 \mathrm{~Hz}, \mathrm{Py}-\mathrm{H}^{3}\right)$, $7.76\left(\mathrm{dd}, 7.58\left(\mathrm{~m}, 1 \mathrm{H}, \mathrm{Ph}-\mathrm{H}^{7,8,9}\right), 5.74\left(\mathrm{~d}, 2 \mathrm{H}, \mathrm{Ph}-\mathrm{H}^{7}\right), 5.48\left(\mathrm{~d}, 2 \mathrm{H}, \mathrm{p}-\mathrm{Cym}-\mathrm{H}^{12}\right), 5.43(\mathrm{dd}, 2 \mathrm{H}\right.$, p-Cym- $\left.\mathrm{H}^{13}\right), 2.7\left(\mathrm{sep}, 1 \mathrm{H}, \mathrm{J}=6.90, \mathrm{CH}\left(\mathrm{CH}_{3}\right)_{2}\right), 2.19\left(\mathrm{~s}, 3 \mathrm{H}, \mathrm{p}-\mathrm{Cym}-\mathrm{CH}_{3}\right), 1.21(\mathrm{~d}, 3 \mathrm{H}, \mathrm{J}=6.90$ $\left.\mathrm{CH}_{3}\right), 1.16\left(\right.$ d. $\left.3 \mathrm{H}, \mathrm{J}=6.90 \mathrm{CH}_{3}\right)$. Elemental Analysis $\left(\mathrm{C}, \mathrm{H}, \mathrm{N}\right.$, weight $\left.\% \mathrm{C}_{22} \mathrm{H}_{24} \mathrm{RuPF}_{6} \mathrm{Cl}^{\circ} \cdot \mathrm{H}_{2} \mathrm{O}\right)$ : Theoretical: $42.9 \%$ C, $4.25 \%$ H, $4.55 \% \mathrm{~N}$. Experimental: $43.12 \%$ C, $3.89 \%$ H, $4.69 \%$ N. Synthesis of Compound $C_{3}$

The prepared $\mathrm{Ru}(\mathrm{II})$ arene dimer $(0.0800 \mathrm{~g}, 1.33 \mathrm{mmol})$ and Schiff base ligand $\mathbf{L 3}(0.100$ $\mathrm{g}, 0.262 \mathrm{mmol})$ were put into a $25 \mathrm{~mL}$ round bottom flask. HPLC grade methanol $(8 \mathrm{~mL})$ was then added. The reaction was then stirred at room temperature for 4 hours. Ammonium hexafluorophosphate $(2.12 \mathrm{~g}, 13.3 \mathrm{mmol})$ was then added directly and the resulting mixture was stirred for 10 minutes, then the reaction mixture was kept in the fridge $\left(4^{\circ} \mathrm{C}\right)$ overnight and solid precipitates were formed. ${ }^{1} \mathrm{H}$ NMR spectrum of the compound showed several peaks in the aromatic region and in the ferrocenyl region. Reaction appeared unsuccessful will be carried out again in the future . 


\section{Synthesis of Compound $C_{4}$}

The prepared $\mathrm{Ru}(\mathrm{II})$ arene dimer $(0.13 \mathrm{~g}, 0.20 \mathrm{mmol})$ and Schiff base ligand $\mathbf{L 4}(0.12 \mathrm{~g}$, $0.41 \mathrm{mmol})$ were put into a $25 \mathrm{~mL}$ round bottom flask. HPLC grade methanol $(8 \mathrm{~mL})$ was then added. The reaction was then stirred at room temperature for 4 hours. Ammonium hexafluorophosphate $(0.170 \mathrm{~g}, 1.02 \mathrm{mmol})$ was then added directly and the resulting mixture was stirred for 10 minutes, then the reaction mixture was kept in the fridge overnight and solid precipitates were formed. The product was then filtered off and dried to yield the product as a dark purple. solid. Yield: $53 \%(0.17 \mathrm{~g}){ }^{1} \mathrm{H}$ NMR $\delta=\left(400 \mathrm{MHz}, \mathrm{CDCl}_{3}\right): 9.30(\mathrm{~s}, 1 \mathrm{H}, \mathrm{CH}=\mathrm{N})$, $8.22\left(\mathrm{~d}, 1 \mathrm{H}, \mathrm{J}=7.73 \mathrm{~Hz}, \mathrm{Py}-\mathrm{H}^{6}\right), 8.05\left(\mathrm{t}, 1 \mathrm{H}, \mathrm{J}=7.73 \mathrm{~Hz}, \mathrm{Py}-\mathrm{H}^{5}\right), 7.70$ (t, J = 6.24 Hz Py-H $\left.{ }^{4}\right)$, $5.88\left(\mathrm{~d}, \mathrm{~J}=6.30 \mathrm{~Hz}, 1 \mathrm{H}, \mathrm{Ph}-\mathrm{H}^{3}\right), 5.49\left(\mathrm{t}, \mathrm{J}=5.67 \mathrm{~Hz}, 2 \mathrm{H}, \mathrm{p}-\mathrm{Cym}-\mathrm{H}^{12}\right), 5.37(\mathrm{~d}, \mathrm{~J}=5.67 \mathrm{~Hz}, 2 \mathrm{H}$, p-Cym- $\left.\mathrm{H}^{13}\right), 5.434 .84(\mathrm{~s}, 2 \mathrm{H}),, 4.55(\mathrm{~d}, \mathrm{~J}=13.53,2 \mathrm{H}), 4.29(\mathrm{~s}, 5 \mathrm{H}) 2.61(\mathrm{sep}, 1 \mathrm{H}, \mathrm{J}=7.00$, $\left.\mathrm{CH}\left(\mathrm{CH}_{3}\right)_{2}\right), 2.24\left(\mathrm{~s}, 3 \mathrm{H}, \mathrm{p}-\mathrm{Cym}-\mathrm{CH}_{3}\right), 1.13\left(\mathrm{~d}, 3 \mathrm{H}, \mathrm{J}=6.53 \mathrm{CH}_{3}\right), 1.07$ (d. $\left.3 \mathrm{H}, \mathrm{J}=6.53 \mathrm{CH}_{3}\right)$. Synthesis of Compound $C_{5}$

The prepared $\mathrm{Ru}(\mathrm{II})$ arene dimer $(0.100 \mathrm{~g}, 0.16 \mathrm{mmol})$ and Schiff base ligand $\mathbf{L 5}(0.0450$ g, $0.147 \mathrm{mmol})$ were put into a $25 \mathrm{~mL}$ round bottom flask. HPLC grade methanol $(8 \mathrm{~mL})$ was then added. The reaction was then stirred at room temperature for 4 hours. Ammonium hexafluorophosphate $(2.12 \mathrm{~g}, 13.3 \mathrm{mmol})$ was then added directly and the resulting mixture was stirred for 10 minutes, then the reaction mixture was kept in the fridge $\left(4^{\circ} \mathrm{C}\right)$ overnight and solid precipitates were formed. ${ }^{1} \mathrm{H}$ NMR spectrum of the compound showed several peaks in the aromatic region making assignments difficult. Reaction condition will be varied and carried out again in future.

Synthesis of Compound $C_{6}$

The prepared $\mathrm{Ru}(\mathrm{II})$ arene dimer $(0.110 \mathrm{~g}, 0.180 \mathrm{mmol})$ and Schiff base ligand $\mathbf{L 6}(0.110$ $\mathrm{g}, 0.360 \mathrm{mmol})$ were put into a $25 \mathrm{~mL}$ round bottom flask. HPLC grade methanol $(8 \mathrm{~mL})$ was 
then added. The reaction was then stirred at room temperature for 4 hours. Ammonium hexafluorophosphate $(0.110 \mathrm{~g}, 0.710 \mathrm{mmol})$ was then added directly and the resulting mixture was stirred for 10 minutes, then the reaction mixture was kept in the fridge overnight and solid precipitates were formed. The product was then filtered off and dried to yield the product as a dark green solid. Yield: $72 \%(0.20 \mathrm{~g}){ }^{1} \mathrm{H} \mathrm{NMR} \delta=\left(400 \mathrm{MHz}, \mathrm{CDCl}_{3}\right): 9.31(\mathrm{~d}, 1 \mathrm{H}, \mathrm{J}=5.52 \mathrm{~Hz}$, Py- $\left.H^{6}\right), 8.48(\mathrm{~s}, 1 \mathrm{H}, \mathrm{CH}=\mathrm{N}), 8.1\left(\mathrm{t}, 1 \mathrm{H}, \mathrm{J}=5.58 \mathrm{~Hz}, \mathrm{Py}-\mathrm{H}^{5}\right), 7.75\left(\mathrm{t}, \mathrm{J}=8.49 \mathrm{~Hz}\right.$ Py-H $\left.{ }^{4}\right), 7.64$ $\left(\mathrm{d}, \mathrm{J}=8.56 \mathrm{~Hz}, 1 \mathrm{H}, \mathrm{Ph}-\mathrm{H}^{3}\right), 5.76\left(\mathrm{~d}, \mathrm{~J}=5.67 \mathrm{~Hz}, 2 \mathrm{H}, \mathrm{p}-\mathrm{Cym}-\mathrm{H}^{12}\right), 5.52(\mathrm{~d}, \mathrm{~J}=6.32 \mathrm{~Hz}, 2 \mathrm{H}, \mathrm{p}-$ Cym- $\left.\mathrm{H}^{13}\right), 5.45(\mathrm{~d}, \mathrm{~J}=6.10 \mathrm{~Hz}, 2 \mathrm{H}) 4.78(\mathrm{~s}, 2 \mathrm{H}, \mathrm{Cp}), 4.49$ (s, 2H, Cp), 4.12 (s, 5H, Cp), 2.76 (sep, $\left.1 \mathrm{H}, \mathrm{J}=6.94, \mathrm{CH}\left(\mathrm{CH}_{3}\right)_{2}\right), 2.21\left(\mathrm{~s}, 3 \mathrm{H}, \mathrm{p}-\mathrm{Cym}_{-} \mathrm{CH}_{3}\right), 1.22\left(\mathrm{~d}, 3 \mathrm{H}, \mathrm{J}=6.95 \mathrm{CH}_{3}\right), 1.17$ (d. $\left.3 \mathrm{H}, \mathrm{J}=6.95 \mathrm{CH}_{3}\right)$.

\section{General UV-vis Spectra Conditions}

The UV-vis spectra of the compounds were measured using a solution of the complexes at a concentration of $100 \mu \mathrm{M}$ in $10 \%$ DMSO and aqueous PBS (pH 7.4). The samples were incubated at $37^{\circ} \mathrm{C}$ and spectra were collected every 30 minutes over a period of 6 hours.

\section{Results and Discussion}

The ruthenium dimer starting material was synthesized by reaction of $\mathrm{RuCl}_{3} \cdot 3 \mathrm{H}_{2} \mathrm{O}$ with an excess of $\alpha$-phellandrene and heated to (reflux) for four hours. The reaction mixture was then concentrated on the rotary evaporator and stored in the fridge overnight. The product was then filtered to yield a bright orange brown solid. The synthetic scheme for the reaction is shown in

\section{Figure 37.}




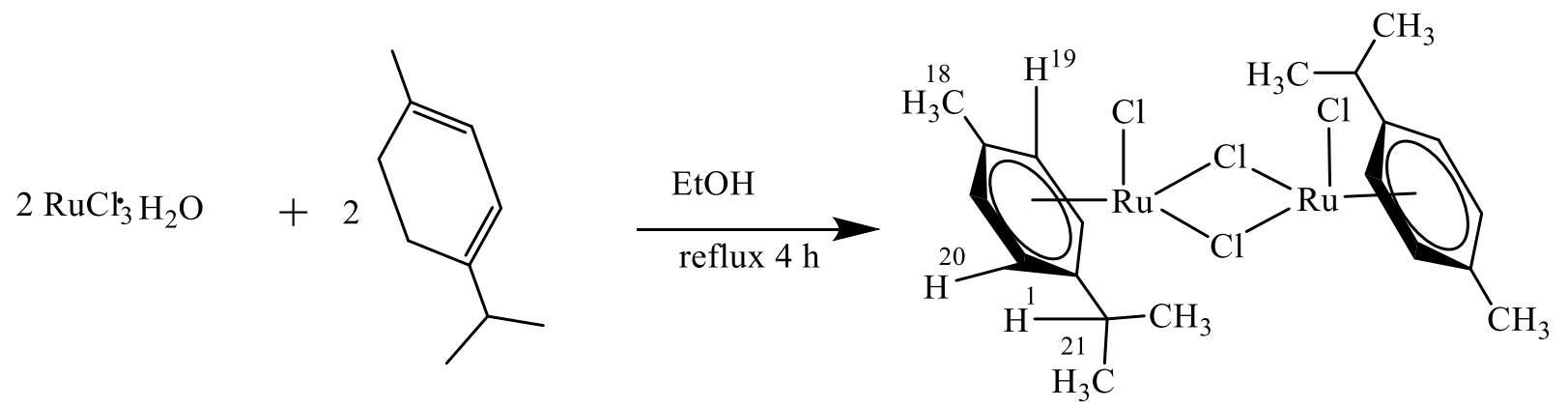

Figure 37. Reaction scheme for the synthesis of $\mathrm{Ru}(\mathrm{II})$ arene dimer starting material.

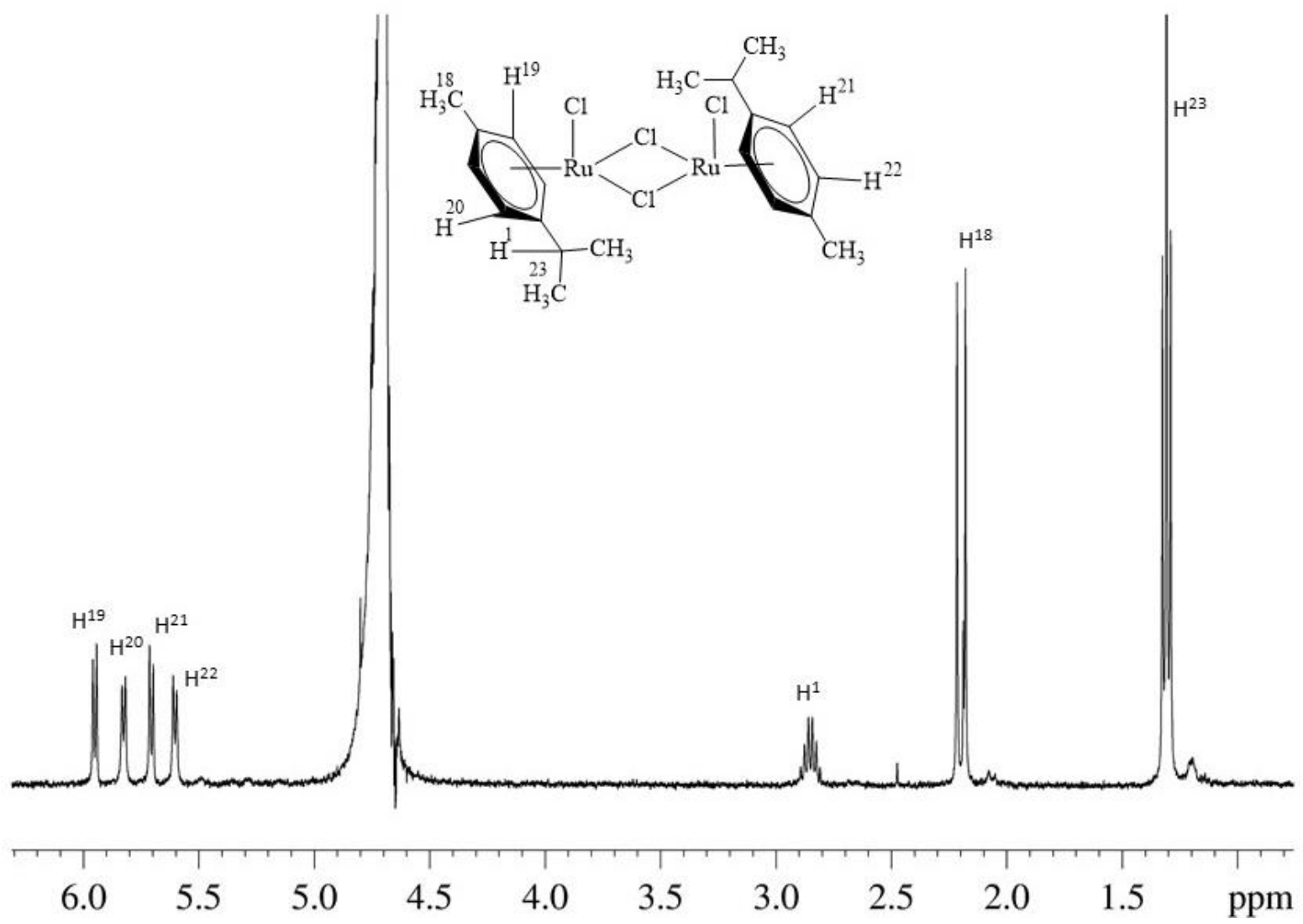

Figure 38. The ${ }^{1} \mathrm{H} N M R$ spectrum of the $\mathrm{Ru}(\mathrm{II})$ arene dimer in $\mathrm{D}_{2} \mathrm{O}$.

The compound was characterized by collecting the ${ }^{1} \mathrm{H}$ NMR spectrum, shown in Figure 38. The hydrogens $\left(\mathrm{H}^{18}\right)$ on the two methyl groups directly bonded to the benzene ring appear upfield in the spectrum as two singlets at chemical shifts $2.22 \mathrm{pm}$ and $2.18 \mathrm{ppm}$. The four unique 
hydrogens, $\mathrm{H}^{19}-\mathrm{H}^{22}$, on the asymmetrical benzene rings appear in the spectrum as four doublets spanning the region of $5.25 \mathrm{ppm}$ to $6.95 \mathrm{ppm}$. Another major diagnostic peak is that of the hydrogen $\left(\mathrm{H}^{1}\right)$ which appears in the spectrum as a septet at the chemical shift $2.85 \mathrm{ppm}$. The twelve hydrogens from the four methyl groups also appears as two doublets at chemical shifts of $1.31 \mathrm{ppm}$. These reported chemical shifts match those reported in literature for the $\mathrm{Ru}(\mathrm{II})$ dimer. The $\mathrm{Ru}(\mathrm{II})$ complexes were then synthesized by reacting the $\mathrm{Ru}(\mathrm{II})$ dimer species with the respective six Schiff base ligands from chapter two.

All four compounds $\mathbf{C}_{\mathbf{1}}, \mathbf{C}_{\mathbf{2}}, \mathbf{C}_{\mathbf{4}}$ and $\mathbf{C}_{\mathbf{6}}$ were synthesized according to one general procedure (Figure 39). The ruthenium dimer and the respective Schiff base ligand were dissolved in HPLC grade methanol, and the reaction mixture was allowed to stir at room temperature for 4 hours. This was to ensure a complete reaction between the Ru compound and the Schiff base ligand. Ammonium hexafluorophosphate (5 equivalents) was then added to the mixture and stirred for 10 minutes. The phosphate was added to the mixture to aid the precipitation of the product. A previous synthetic attempt used tetrabutylammonium hexafluorophosphate $\left(\mathrm{Bu}_{4} \mathrm{NPF}_{6}\right.$ ), where the ${ }^{1} \mathrm{H}$ NMR spectra of the isolated compound showed significant precipitation of the $\mathrm{Bu}_{4} \mathrm{NPF}_{6}$ salt as opposed to the desired product. Hence, the process was modified by changing the salt used. Each complex was characterized using ${ }^{1} \mathrm{H}$ NMR. 


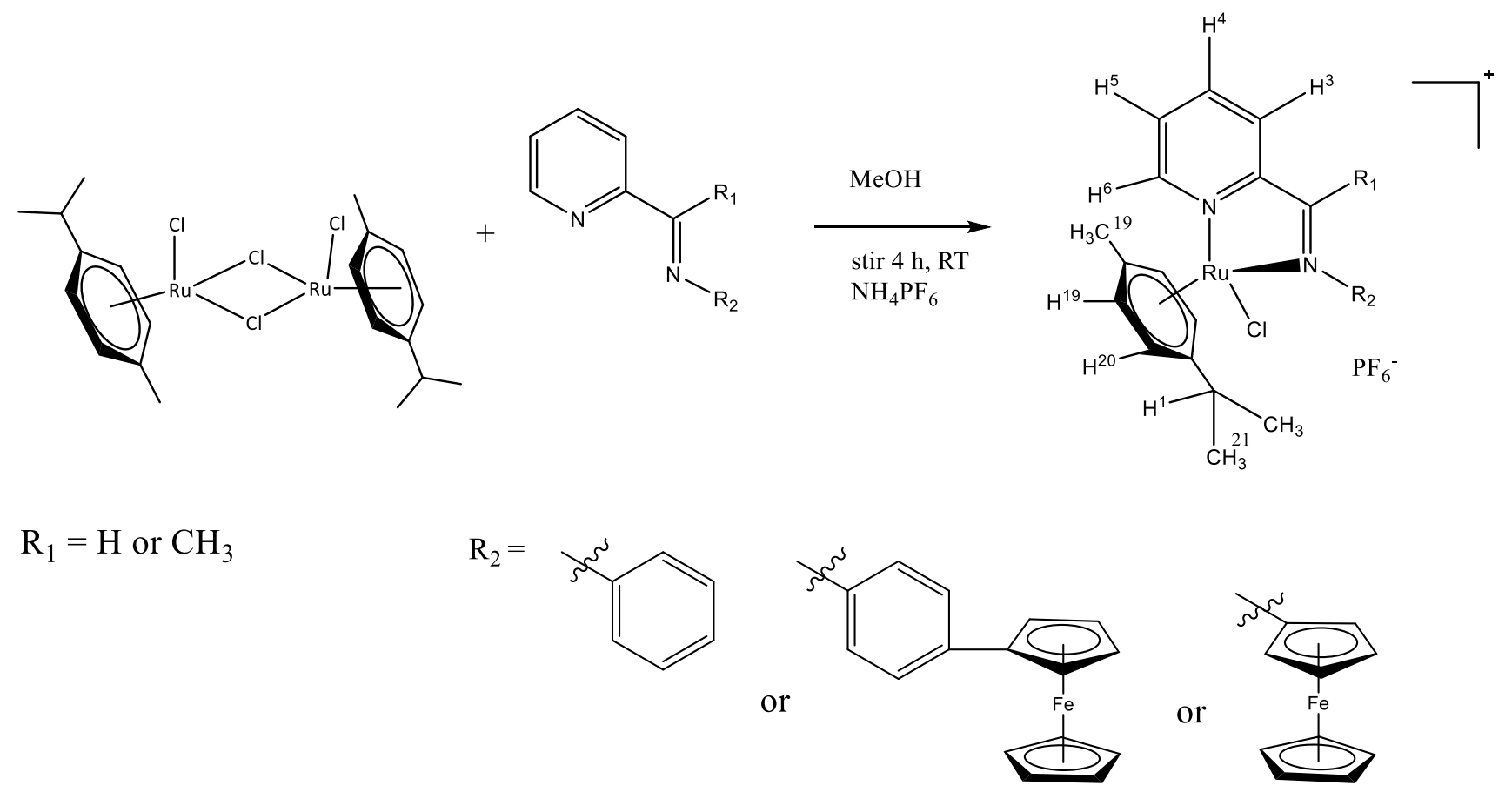

Figure 39. General reaction scheme for the $\mathrm{Ru}(\mathrm{II})$ arene Schiff base compounds.

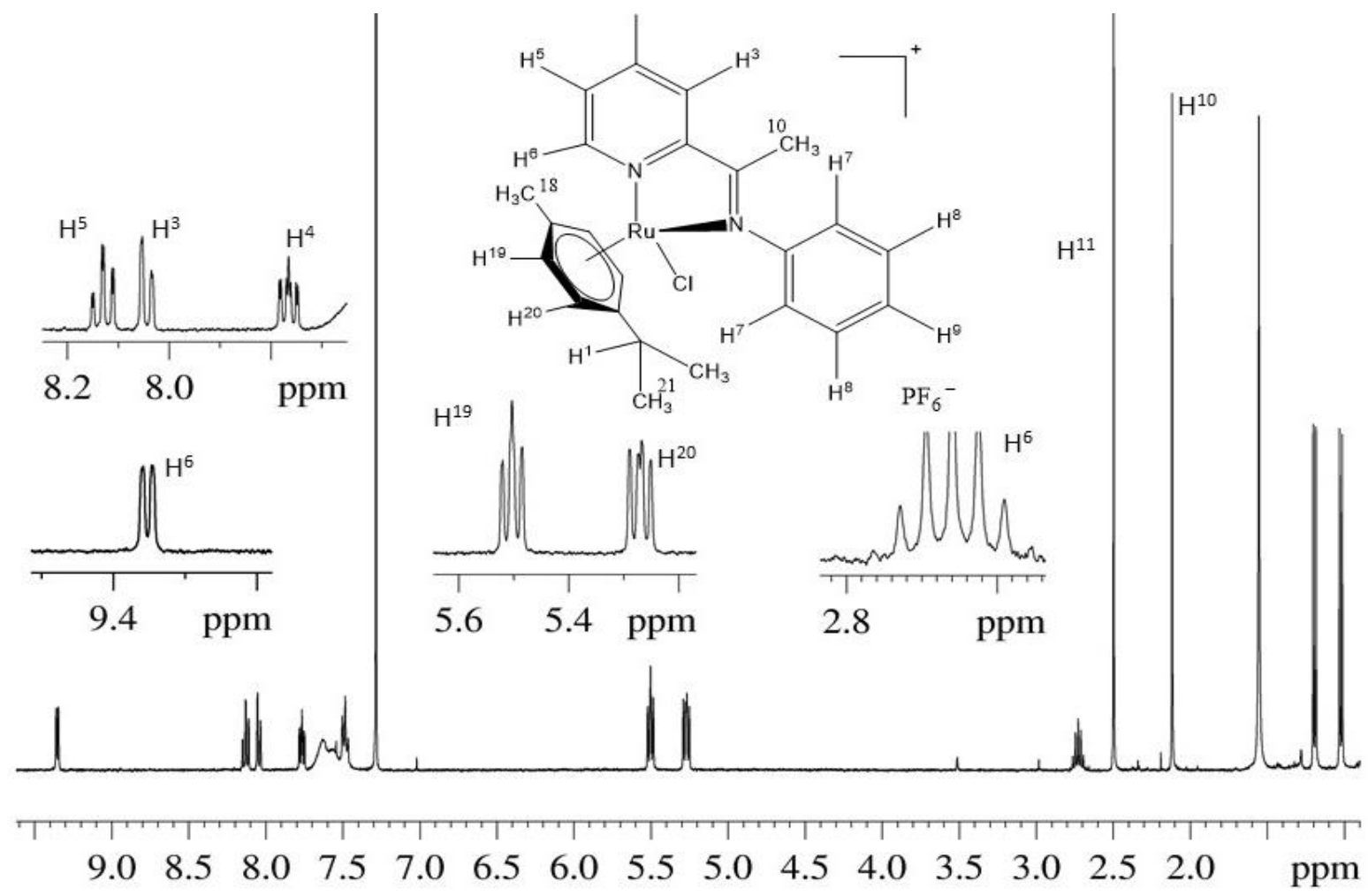

Figure 40. The ${ }^{1} \mathrm{H}$ NMR spectrum of complex $\mathbf{C}_{1}$ in $\mathrm{CDCl}_{3}$. 
In the ${ }^{1} \mathrm{H}$ NMR spectrum (Figure 40) of complex $\mathbf{C}_{\mathbf{1}}$, the $\mathrm{Py}-\mathrm{H}^{6}$ and $\mathrm{Py}-\mathrm{H}^{3}$ appear as doublets at $9.4 \mathrm{ppm}$ and $8.05 \mathrm{ppm}$ respectively. In the aromatic region, $\mathrm{Py}-\mathrm{H}^{4}$ appears as a triplet at $7.80 \mathrm{ppm}$ whereas $\mathrm{H}^{5}$ also appears as another triplet at $8.15 \mathrm{ppm}$. Additionally, the hydrogens $\mathrm{H}^{7}, \mathrm{H}^{8}$, and $\mathrm{H}^{9}$ on the benzene ring also appear as a multiplet at $7.50 \mathrm{ppm}$. Compared to the hydrogens on ligand $\mathbf{L} \mathbf{1}$, these hydrogens on $\mathbf{C}_{\mathbf{1}}$ are shifted further downfield to higher chemical shifts. This may be due to deshielding of the hydrogens as a result of the +2 oxidation state of the $\mathrm{Ru}$ ion which strongly pulls away electrons from the hydrogens. Two other triplets in the aromatic region are also observed at $5.55 \mathrm{ppm}$ and $5.35 \mathrm{ppm}$ due to the two different hydrogen environments, $\mathrm{H}^{19}$ and $\mathrm{H}^{20}$ respectively on the ring in the cymene group. Another major diagnostic peak for the synthesis of this complex is the appearance of the septet at $2.75 \mathrm{ppm}$ due to the hydrogen labelled $\mathrm{H}^{1}$ that is para to the methyl group on the cymene ring. These three different hydrogen environments on the cymene ring appear shifted upfield relative to the hydrogens on the $\mathrm{Ru}$ (II) dimer starting material. Another group of hydrogens are those of the methyl group directly bonded to the cymene ring, $\mathrm{H}^{18}$ which appears as a singlet at $2.50 \mathrm{ppm}$. Another singlet due to the three hydrogens on the methyl group $\mathrm{H}^{10}$, bonded to the iminic carbon is also shifted upfield in the spectrum to $2.22 \mathrm{ppm}$ compared to $2.67 \mathrm{ppm}$ on the ligand $\mathbf{L 1}$. Similar to the observations made for the hydrogens on the cymene ring, the six hydrogens of the isopropyl group on the cymene are also shifted further upfield to $1.12 \mathrm{ppm}$ and $1.03 \mathrm{ppm}$ from 2.18 and 1.31 respectively in the Ru-dimer. Overall, the resonances observed matches similar compounds that have been reported in literature confirming a successful synthesis of the compound

Having successfully synthesized $\mathbf{C}_{\mathbf{1}}$, the same general procedure was used to synthesize complex $\mathbf{C}_{2}$. The compound was characterized by collecting the ${ }^{1} \mathrm{H}$ NMR spectrum in Figure 41 


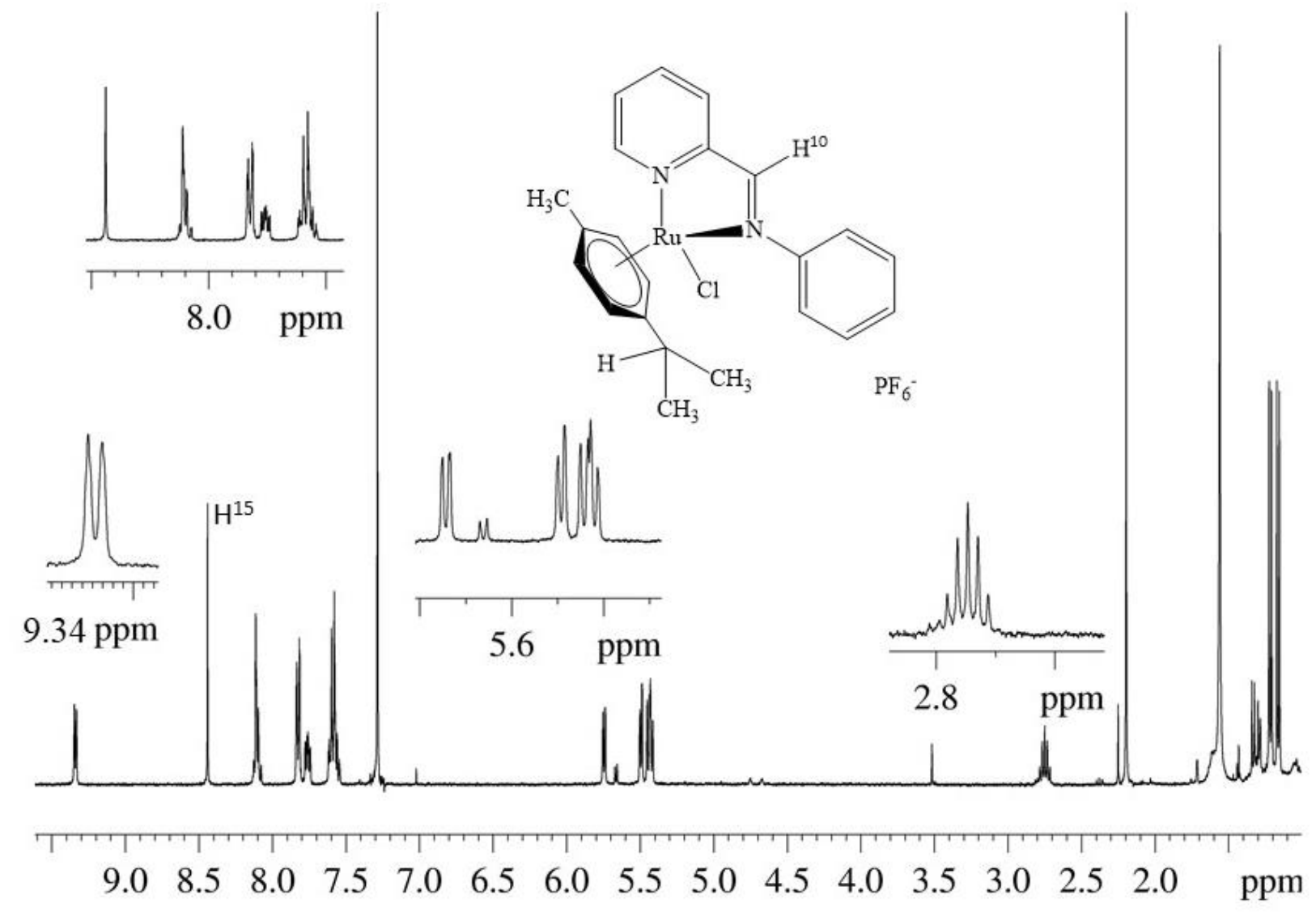

Figure 41. The ${ }^{1} \mathrm{H}$ NMR spectrum of complex $\mathbf{C}_{2}$ in $\mathrm{CDCl}_{3}$.

The ${ }^{1} \mathrm{H}$ NMR spectrum of $\mathbf{C}_{\mathbf{2}}$ is similar to $\mathbf{L 2}$. The four hydrogens on the pyridine as well as the three different hydrogens of the benzene ring appear in the spectrum spanning the region of $9.34 \mathrm{ppm}$ to $7.6 \mathrm{ppm}$ as observed in compound $\mathbf{C}_{\mathbf{1}}$. The major difference between the spectrum of $\mathbf{C}_{1}$ and $\mathbf{C}_{2}$ is the replacement of the methyl group of $\mathbf{C}_{\mathbf{1}}$ by a hydrogen, $\mathrm{H}^{10}$ which appears downfield at $8.44 \mathrm{ppm}$. Comparing these chemical shifts of $\mathbf{C}_{2}$ to the Schiff base ligand $\mathbf{L 2}$, a similar observation made for compound $\mathbf{C}_{\mathbf{1}}$ was seen where all the hydrogens on the pyridine and benzene rings were shifted further downfield to higher chemical shifts relative to the free Schiff base. Finally, as observed in complex $\mathbf{C}_{\mathbf{1}}$ the six different hydrogens of the cymene were all shifted upfield relative to the $\mathrm{Ru}$ (II) dimer staring material. Results of the 
elemental analysis of the composition of carbon, hydrogen and, nitrogen and was consistent with the calculated percentages confirming a successful synthesis of $\mathbf{C}_{1}$ and by extension $\mathbf{C}_{2}$ as well Another synthesis was carried out following the synthetic procedure used to synthesize compound $\mathbf{C}_{1}$ and $\mathbf{C}_{2}$ to make $\mathbf{C}_{3}$. However, the reaction did not appear to work, as the NMR showed several complex peaks within the aromatic region in the spectrum. The reaction conditions are being modified to achieve a better results.

Another $\mathrm{Ru}(\mathrm{II})$ arene Schiff base compound, $\mathbf{C}_{\mathbf{4}}$ was synthesized by reacting the $\mathrm{Ru}$ dimer with L4 and characterized by collecting the ${ }^{1} \mathrm{H}$ NMR spectrum (Figure 42).

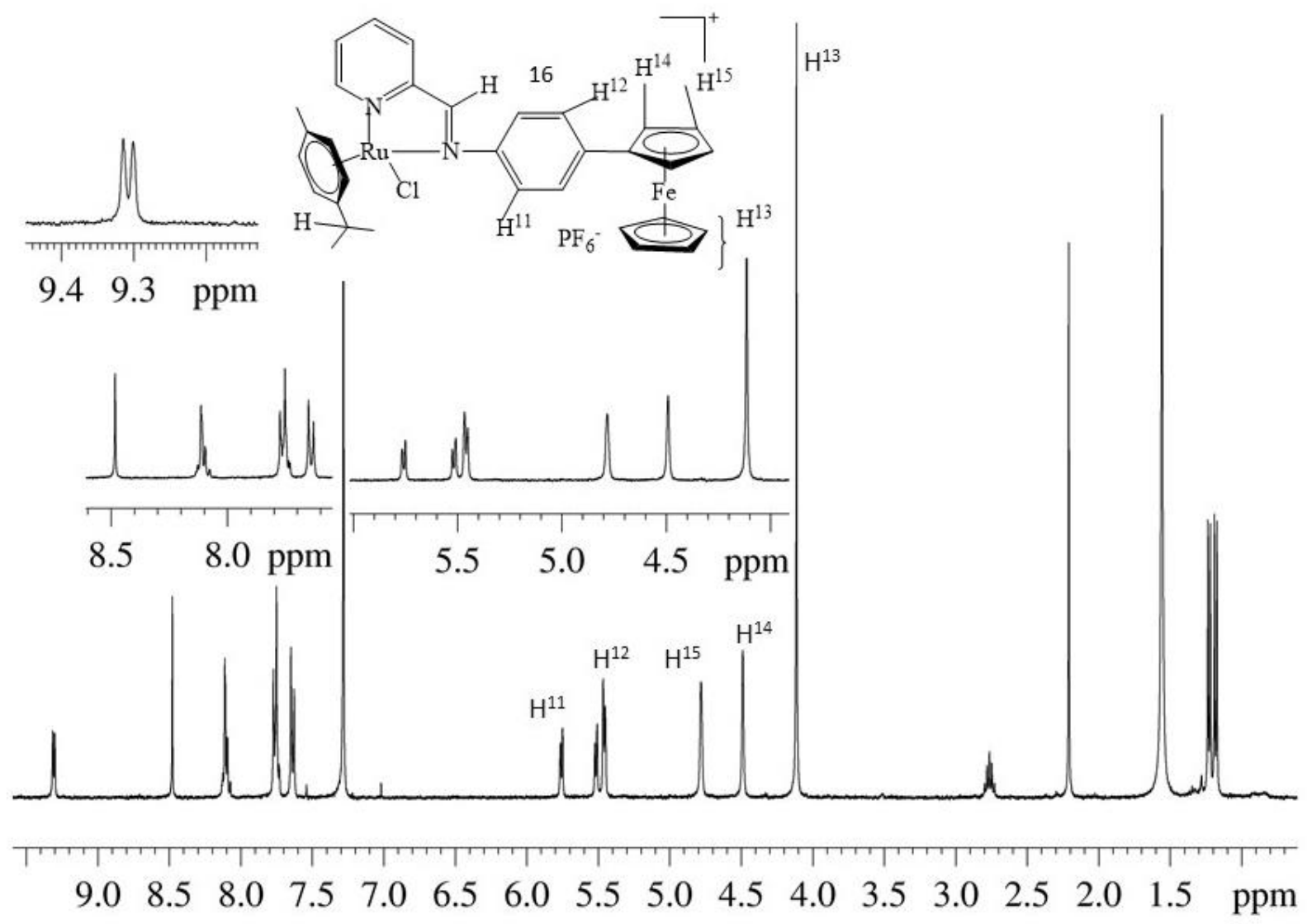

Figure 42. The ${ }^{1} \mathrm{H}$ NMR spectrum of complex $\mathbf{C}_{4}$ in $\mathrm{CDCl}_{3}$.

The ${ }^{1} \mathrm{H}$ NMR spectrum of $\mathbf{C}_{\mathbf{4}}$ appears similar to complex $\mathbf{C}_{\mathbf{2}}$. As expected, the ${ }^{1} \mathrm{H}$ NMR 
spectrum resonances show spanning the spectrum from $9.3 \mathrm{ppm}$ to $7.6 \mathrm{ppm}$ due to the pyridine and phenyl rings . However, unlike $\mathbf{C}_{2}$ the structure of the compound is modified to include ferrocene which introduces three new peaks into the spectrum. First, two singlets due to $\mathrm{H}^{14}$ and $\mathrm{H}^{15}$ on the substituted aromatic ring of ferrocene is seen in the region of $4.8 \mathrm{ppm}$ and $4.5 \mathrm{ppm}$. The five hydrogens of the unsubstituted aromatic $\mathrm{H}^{13}$, also show up as an intense singlet peak at chemical shift $4.1 \mathrm{ppm}$. Relative to the Schiff base ligand $\mathbf{L} \mathbf{4}$ the ferrocene peaks appear shifted slightly downfield. As a general trend so far, all the hydrogen environments of the cymene shift upfield after bonding to the $\mathrm{Ru}(\mathrm{II})$ metal.

The fifth synthetic attempt was $\mathbf{C}_{5}$ using the same procedure as before. However, the reaction did not work as the NMR showed several peaks spanning the region $5.5 \mathrm{ppm}$ to $8.5 \mathrm{ppm}$ in the peaks in the spectrum. The reaction conditions are being changed to possibly make this compound.

The last successful compound synthesized was the $\mathrm{Ru}(\mathrm{II})$ compound $\mathbf{C}_{6}$ using the same procedure as described earlier and characterized by collecting the ${ }^{1} \mathrm{H}$ NMR spectrum. The ${ }^{1} \mathrm{H}$ NMR spectrum of compound $\mathbf{C}_{6}$ (Figure 43 ) was used to confirm the synthesis of the compound. 


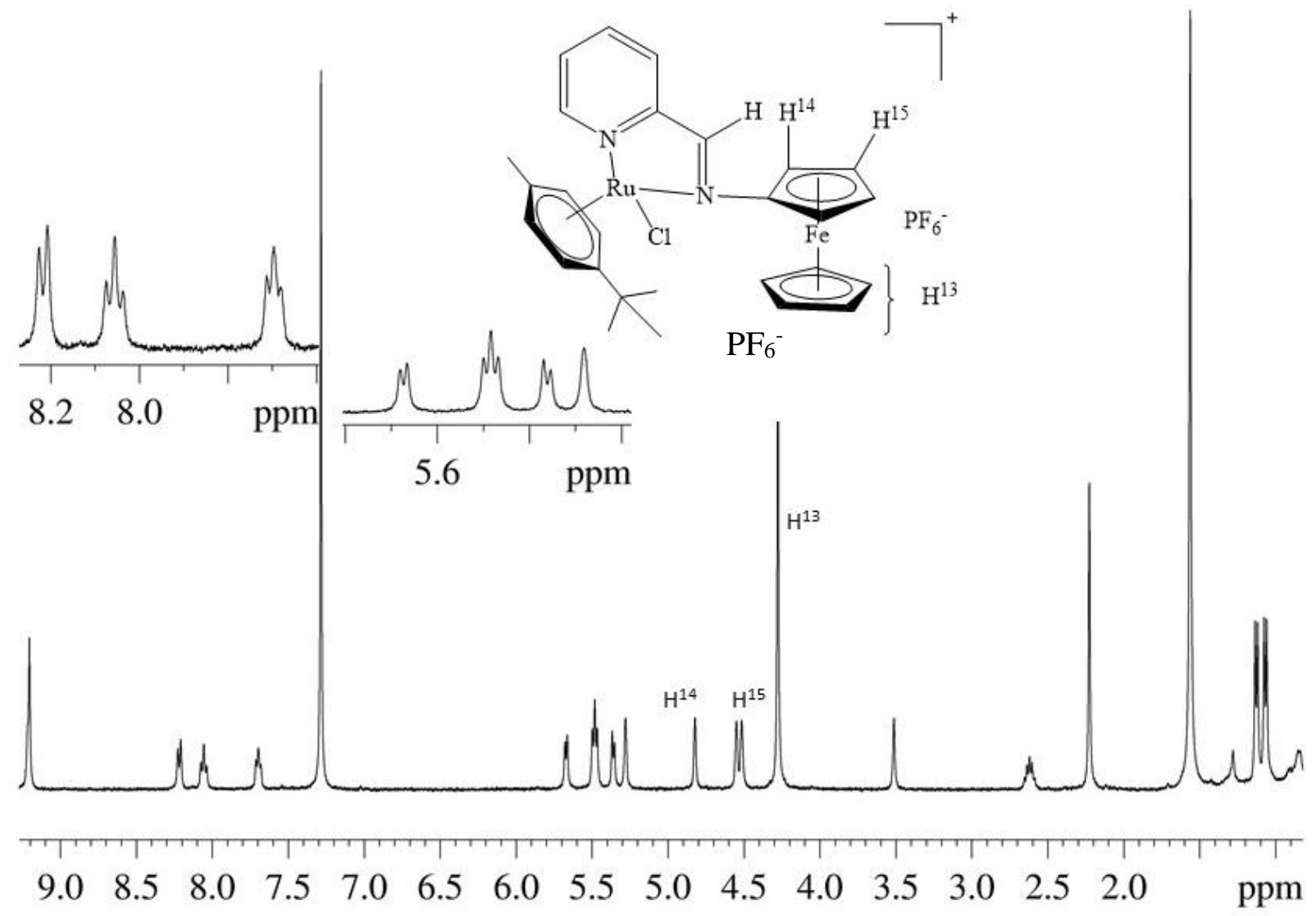

Figure 43. The ${ }^{1} \mathrm{H}$ NMR spectrum of complex $\mathbf{C}_{6}$ in $\mathrm{CDCl}_{3}$.

The complex $\mathbf{C}_{6}$ shows ${ }^{1} \mathrm{H}$ NMR spectrum similar to complex $\mathbf{C}_{4}$. However, the hydrogen, $\mathrm{H}^{18}$ of the imine appears at $9.30 \mathrm{ppm}$. Resonances of two doublets and two triplets for the four hydrogen environments on the pyridine ring span the spectrum from $9.30 \mathrm{ppm}$ to 5.70 $\mathrm{ppm}$. The spectrum shows a singlet at $4.85 \mathrm{ppm}$ and doublet at $4.55 \mathrm{ppm}$ due to the hydrogens $\mathrm{H}^{14}$ and $\mathrm{H}^{15}$ on the substituted cyclopentadienyl ring of ferrocene. Another intense singlet peak at 4.25 ppm was assigned to the five hydrogens, $\mathrm{H}^{13}$ of the unsubstituted cyclopentadienyl ring. This range of chemical shifts agrees with the ferrocenyl peaks of $\mathbf{C}_{\mathbf{4}}$ and those of Schiff base $\mathbf{L 6}$, however, as seen in $\mathbf{C}_{4}$, the ferrocene peaks assigned to $\mathbf{C}_{6}$ are shifted slightly downfield relative to $\mathbf{L 6}$. The major difference between $\mathbf{C}_{\mathbf{4}}$ and $\mathbf{C}_{6}$ are the two doublets from the four hydrogens due to the additional phenyl group attached to the ferrocene. These doublets appear at the chemical 
shifts 5.45 ppm and 5.55 ppm in $\mathbf{C}_{\mathbf{4}}$ but are absent in $\mathbf{C}_{6}$. The observed NMR signals suggest a successful synthesis bringing the total number of Ru Schiff base complexes prepared to 4 $U V$-vis experiments

An important step in the mechanism of action of anticancer drugs is their ligand exchange behavior. Therefore, the stability of the four successfully synthesized ruthenium arene complexes $\mathbf{C}_{1}, \mathbf{C}_{2}, \mathbf{C}_{4}$, and $\mathbf{C}_{6}$ were all studied in $10 \%$ DMSO and aqueous PBS at a pH of 7.4 and a temperature of $37^{\circ} \mathrm{C}$. The UV-vis spectrum of each compound was collected every 30 minutes for a period of 6 hours using a concentration of $100 \mu \mathrm{M}$. Over the six-hour period, the measured spectra for all of the compounds did not vary. The spectrum of the compound compound $\mathbf{C}_{1}$ is shown in Figure 45 while the spectra for the remaining compounds can be found in .

Studies have shown that the presence of the arene group at three coordinate site of the $\mathrm{Ru}(\mathrm{II})$ ion alters the electron distribution of the compound and stabilizes the $\mathrm{Ru}(\mathrm{II})$ the compound towards ligand exchange. ${ }^{43}$ This behavior of compounds $\mathbf{C}_{\mathbf{1}}, \mathbf{C}_{\mathbf{2}}, \mathbf{C}_{\mathbf{4}}$, and $\mathbf{C}_{\mathbf{6}}$ in aqueous PBS are consistent with the earlier reported observations on $\mathrm{Ru}(\mathrm{II})$ arene compounds. It was therefore proposed that the four compounds are stable under physiological conditions of $37^{\circ} \mathrm{C}$ and $\mathrm{pH}$ of 7.4. Comparing the UV-vis spectrum of ligand $\mathbf{L} 2$ and $\mathbf{L} \mathbf{4}$ to their respective complexes, it can be observed that, the stability of the ligands were enhanced after binding to the metal. 


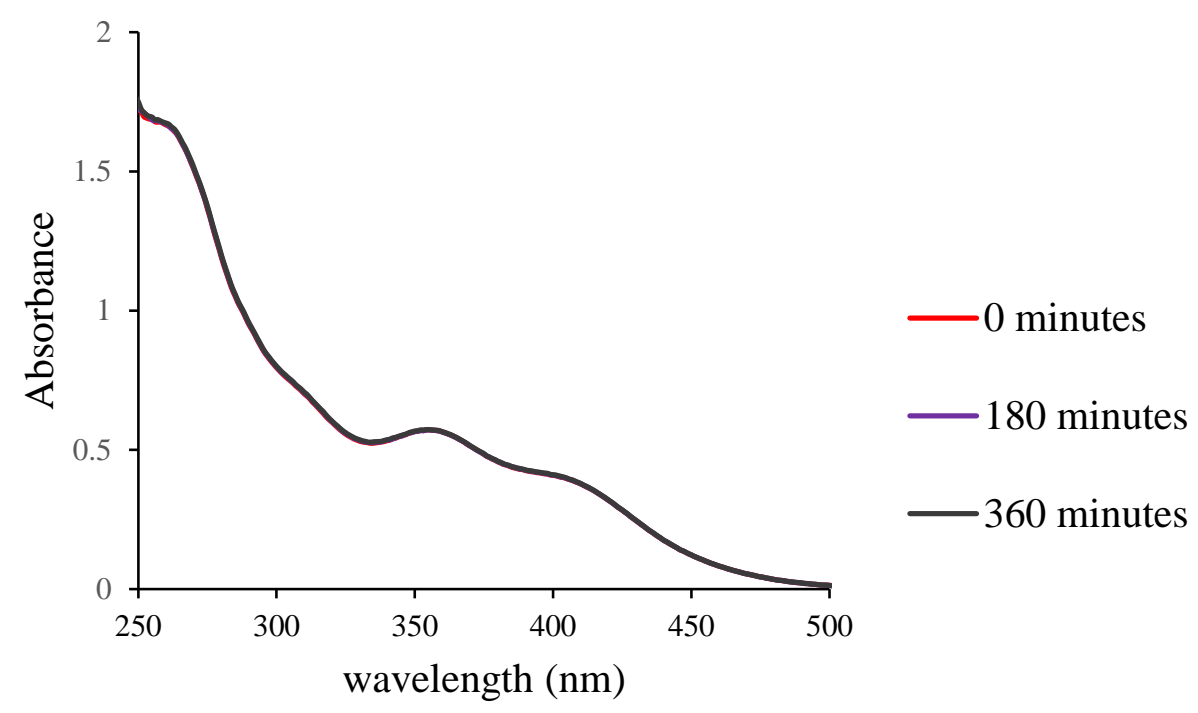

Figure 44. UV-vis spectrum of $100 \mu \mathrm{M}$ solution of $\mathbf{C}_{1}$ in $10 \%$ DMSO and PBS(aq) at a pH of 7.4 and a temperature of $37{ }^{\circ} \mathrm{C}$.

\section{Conclusion}

In all, four $\mathrm{Ru}(\mathrm{II})$ compounds, $\mathbf{C}_{\mathbf{1}}, \mathbf{C}_{\mathbf{2}}, \mathbf{C}_{\mathbf{4}}$ and $\mathbf{C}_{\mathbf{6}}$, have been synthesized according to one general procedure. The compounds have so far been characterized by ${ }^{1} \mathrm{H}$ NMR spectroscopy. In addition, compound $\mathbf{C}_{2}$ has been confirmed by elemental analysis. Efforts were made to synthesize the remaining compounds $\mathbf{C}_{\mathbf{3}}$ and $\mathbf{C}_{5}$, but the resulting NMR spectra were difficult to interpret. By varying the mole ratios of the reaction and carrying out the reaction for a longer duration, it is hoped that the complexes will be prepared. The stability of the 4 prepared compounds in aqueous buffer was also evaluated and all four complexes have so far proved very stable. These 4 compounds will be further studied to establish the binding behavior to HSA. 


\section{CHAPTER IV: PRELIMINARY STUDIES ON THE INTERACTION \\ BETWEEN THE RUTHENIUM(II) ARENE COMPLEXES \\ AND HUMAN SERUM ALBUMEN}

\section{Introduction}

Protein binding is an important consideration in the mechanism of action of any pharmaceutical. It is believed that most ligands present in human blood bind to plasma proteins, and, to a varying extent, these bindings are reversible. ${ }^{59}$ Protein binding facilitates drug solubility in human plasma, enhancing its delivery to the target tissue, which is important in the case of low-soluble, hydrophobic chemicals. Drug binding with the human serum albumin (HSA) protein minimizes its toxicity and may potentially increase the in vivo half-life of a therapeutic agent. ${ }^{59}$

$\mathrm{Ru}(\mathrm{II})$ compounds bind to metal-transporting proteins from human blood such as human serum albumin (HSA) and serum transferrin (Tf). However, the binding affinity of ruthenium compounds to these two proteins revealed that HSA bind more favorably than transferrin. ${ }^{3,61}$ Transferrin is a blood plasma protein that transports iron into the cells by binding to the transferrin-receptor (TfR) on the cell membrane.${ }^{62} \mathrm{HSA}$ is the most abundant protein in plasma and makes up approximately half of the protein found in human blood with a concentration of about $5 \mathrm{~g} / 100 \mathrm{~mL} .{ }^{63,64,66}$ This protein (Figure 46) is comprised of 585 amino acids in a single polypeptide chain, with three R-helical domains (I-III). Each helical domain has two subdomains A and B. The protein contains 17 disulfide bridges which stabilizes the helical structure. ${ }^{63,64,65}$ The disulfide bridges make the helical, globular structure rigid, but provide flexibility to enable the protein to undergo conformational changes in response to changes in the surrounding medium. ${ }^{64}$ 


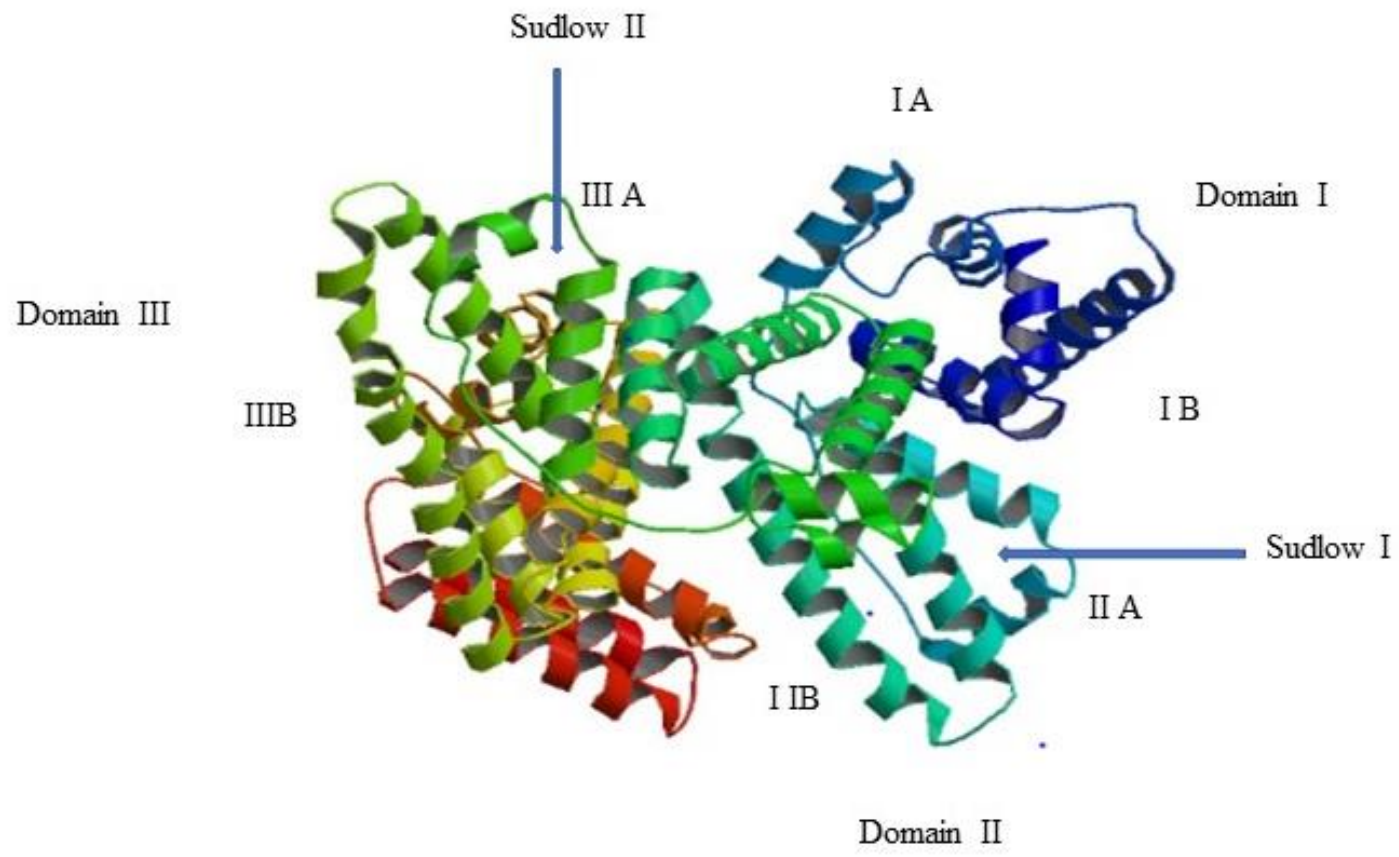

Figure 45. Crystal structure of HSA showing the domain-binding sites (Sudlow I and Sudlow II). ${ }^{67}$

Studies by Sudlow et al. in the 1970s revealed two drug binding sites on HSA. These principal regions of drug binding sites in albumin are found in hydrophobic cavities in subdomains IIA and IIIA. These binding sites are called Sudlow I and Sudlow II, respectively and the tryptophan residue in HSA is located in Sudlow I (Trp-214). ${ }^{67}$ Almost the entire fluorescence of HSA is produced by the tryptophan residue. Albumin principally functions as a carrier protein which binds and transports fatty acids, hormones, metabolites, and drugs. ${ }^{64,65,66}$ The binding affinity of a molecule to HSA, therefore regulates the distribution and metabolism of drugs which necessitates HSA-ligand interaction studies since strong binding may reduce bioavailability and/or increase the drug's in vivo half-life. ${ }^{66,67}$

Fluorescence spectroscopy is a common technique that is employed to investigate the interaction between a drug and HSA. The technique enables the tryptophan residue from which the fluorescence was obtained to be verified and hence determine the number of sites and binding 
constant, $\mathrm{K}_{\mathrm{b}}$ of the interaction between the protein and the drug. It is also possible to identify the type of binding that occurs between the HSA protein and the drug and the mechanism by which the binding occurs.

The four synthesized $\mathrm{Ru}(\mathrm{II})$ arene Schiff base compounds, were evaluated for their interaction with HSA. This investigation is necessary to establish whether the compounds could potentially target proteins, which will impact the bioavailability and distribution of the compounds.

\section{Experimental}

\section{General Materials and Methods}

Human serum albumin was acquired from Sigma Aldrich as a lyophilized powder and used as received. The remaining chemicals used were purchased from Fisher Scientific, Sigma Aldrich, or Oakwood Chemical. All chemicals acquired were used as received. The synthesized compounds were also used as they were prepared as described in chapter 3.

\section{Instrumentation}

The fluorescence spectrometer used was a VARIOSKAN LUX from Thermo Fisher equipped with SkanIt software. The experiments were run in F-brand Flat bottom 96-well plates. The incubator used was a Fisher brand IsoTemp. The fluorescence data obtained were processed in Excel.

\section{General Fluorescence Experimental Conditions}

A stock solution of HSA $(0.110 \mathrm{mM}, 5.00 \mathrm{~mL})$ was prepared using aqueous PBS at a $\mathrm{pH}$ of 7.4 and stored in the fridge. Then $50 \mu \mathrm{M}$ solution of each of the $\mathrm{Ru}(\mathrm{II})$ complexes were also prepared in $10 \%$ DMSO and aqueous PBS. After preparing the samples, $47.5 \mu \mathrm{L}$ of the stock solution of HSA was placed in 11 different vials. To the first vial, $30 \mu \mathrm{L}$ of the prepared complex solution was added. To the second up to the tenth vial the complex solutions were added in increasing amounts of $30 \mu \mathrm{L}$ of the previous amount. Aqueous PBS was then added to 
make a final volume of $600 \mu \mathrm{L}$. The stock solutions HSA- complex were incubated for a period of 1 hour at a temperature of $37^{\circ} \mathrm{C}$ and then each was transferred as triplicates into a 96-well plates. The excitation wavelength was set at $280 \mathrm{~nm}$ and the emission spectra were collected at $299 \mathrm{~nm}$ to $600 \mathrm{~nm}$. Another batch of the measurements were also carried out following the same procedure but incubated at $25^{\circ} \mathrm{C}$.

\section{Results and Discussion}

Fluorescence quenching, a widely used technique for studying the binding affinities between HSA and organic or inorganic complexes was employed to investigate the interaction of complexes $\mathrm{C}_{\mathbf{1}}, \mathbf{C}_{2}, \mathbf{C}_{\mathbf{4}}$ and $\mathbf{C}_{\mathbf{6}}$ with HSA. The technique shows a decrease in the quantum yield of fluorescence from a fluorophore induced by molecular interactions with a quencher molecule. Albumin proteins have intrinsic fluorescence due to the presence of three fluorophores: tryptophan, tyrosine and phenylalanine. Phenylalanine and tyrosine are reported to contribute to fluorescence quenching by a small amount. Almost the entire fluorescence observed from HSA is produced from the tryptophan residue in Sudlow I. ${ }^{62}$ The fluorescence intensity detected as a function of the concentration of complex $\mathbf{C}_{2}$ by exciting HSA at $280 \mathrm{~nm}$ and collecting its emission spectrum from $299 \mathrm{~nm}$ to $600 \mathrm{~nm}$ is shown in Figure 46. The spectra yielded a $\lambda$ max of $306 \mathrm{~nm}$. 


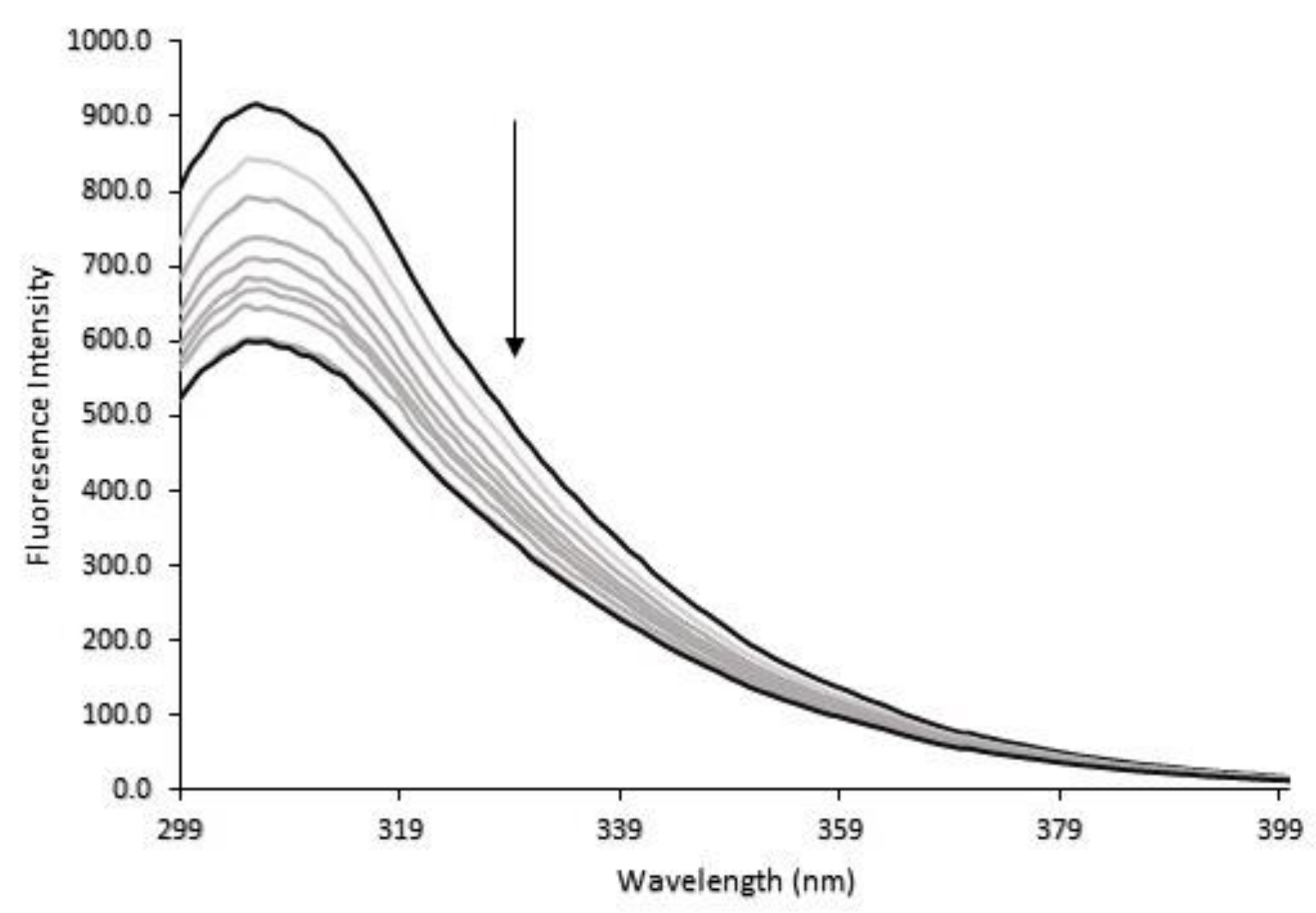

Figure 46. Fluorescence spectra of HSA $(2.5 \mu \mathrm{M})$ in the presence of increasing concentration of $\mathbf{C}_{2}$ from $0 \mu \mathrm{M}$ up to $25 \mu \mathrm{M}$ at $37^{\circ} \mathrm{C}$ and $\mathrm{pH}$ of 7.4 .

As the concentration of the complex increases, the HSA fluorescence intensity decreases. The quenching process occurring may be either static or dynamic. Dynamic quenching occurs when the interaction between the quencher and the excited state of the fluorophore occurs through collisions during the life-time of the fluorophore excited state. If the quenching process is static, the interaction between the fluorophore and quencher occurs in the ground state, with formation of a new species which is not luminescent. ${ }^{62}$

The Stern-Volmer equation is commonly used to determine the type of quenching mechanism by analyzing the relation: 
$\mathrm{F}_{\mathrm{o}} / \mathrm{F}=\mathrm{K}_{\mathrm{sv}}[\mathrm{Q}]+1=\tau_{o} \mathrm{~K}_{\mathrm{q}}[\mathrm{Q}]+1$

where $F_{o}$ and $F$ are the fluorescence intensities in the absence and presence of the quencher, respectively, $\mathrm{K}_{\mathrm{sv}}$ is the Stern-Volmer quenching constant, $\mathrm{K}_{\mathrm{q}}$ is the bimolecular quenching constant and $\tau_{o}$ is the average lifetime of the fluorophore without the quencher which is approximately $10^{-8} \mathrm{~s}$. From the equation, a plot of $\mathrm{F}_{\mathrm{o}} / \mathrm{F}$ against the concentration (Figure 46) of each of the complexes yielded a straight line whose slope was equal to the value of $\mathrm{K}_{\mathrm{sv}}$.

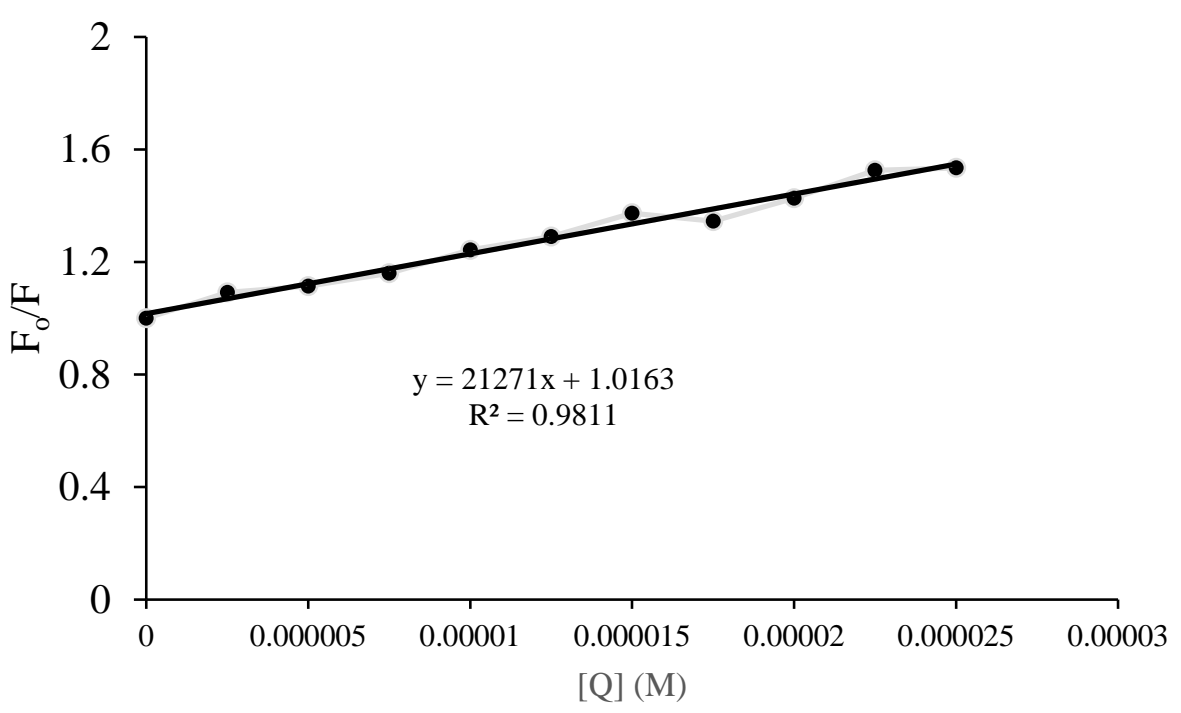

Figure 47. Stern-Volmer plot for $\mathbf{C}_{2}$.

A plot of $F_{0} / F$ against the concentration of the complex $\mathbf{C}_{2}$ yielded a straight line with a slope of 21271 and an intercept of 1.02. Comparing the equation of the line to the Stern-Volmer equation, $\mathrm{K}_{\mathrm{sv}}$ equals the slope of the curve. The same approach was used to determine the $\mathrm{K}_{\mathrm{sv}}$ values (Table 1) for the interaction between $\mathbf{C}_{4}$ and $\mathbf{C}_{6}$ with HSA. The Stern-Volmer quenching constant $\mathrm{K}_{\mathrm{sv}}$ were in the range of $2.10-4.10 \times 10^{4} \mathrm{M}^{-1}$. These calculated values are consistent with $\mathrm{K}_{\mathrm{sv}}$ measures that have been reported for ruthenium(II) arene complexes. ${ }^{69}$ 
From the Stern-Volmer equation, it can be deduced that:

$\tau_{o} \mathrm{~K}_{\mathrm{q}}=\mathrm{K}_{\mathrm{sv}}$, therefore, for $\mathbf{C}_{2}$

$\tau_{o} \mathrm{~K}_{\mathrm{q}}=21271$

$\mathrm{K}_{\mathrm{q}}=21271 / 10^{-8}$

$\mathrm{K}_{\mathrm{q}}=2.1 \times 10^{12} \mathrm{M}^{-1} \mathrm{~s}^{-1}$

A similar approach was followed to determine the bimolecular quenching constants $\left(\mathrm{K}_{\mathrm{q}}\right)$ for both $\mathbf{C}_{4}$ and $\mathbf{C}_{6}$. The bimolecular quenching constants also ranged from $2.1-4.1 \times 10^{12} \mathrm{M}^{-1} \mathrm{~s}^{-1}$ and were found to be consistent with earlier reported bimolecular quenching constants for similar compounds. These observed constants are much greater than $2.0 \times 10^{10} \mathrm{~mol} \mathrm{~L}^{-1} \mathrm{~s}^{-1}, 65,68$ the maximum value for dynamic quenching, indicating that the fluorescence quenching occurred via the static quenching mechanism.

$\mathrm{K}_{\mathrm{b}}$ and the number of binding sites " $\mathrm{n}$ " were calculated by generating a second plot from the modified Stern-Volmer equation:

$\log \left(\mathrm{F}_{\mathrm{o}}-\mathrm{F}\right) / \mathrm{F}=\mathrm{n} \log [\mathrm{Q}]+\log \mathrm{K}_{\mathrm{b}}$

A graph of $\log \left(\mathrm{F}_{\mathrm{o}}-\mathrm{F}\right) / \mathrm{F}$ against $\log [\mathrm{Q}]$ for complex $\mathbf{C}_{2}$ (Figure 48) also yielded a straight line with slope equal to " $n$ ". The binding constants were calculated by finding the antilog of the intercept on the $\log \left(\mathrm{F}_{\mathrm{o}}-\mathrm{F}\right) / \mathrm{F}$ axis. $\mathrm{K}_{\mathrm{b}}$ values calculated were also in the range of $3.6-12.2 \times 10^{3}$ $\mathrm{M}^{-1}$ (Table 1). These values were also consistent with similar $\mathrm{Ru}(\mathrm{II})$ piano-stool compounds already reported in the literature. ${ }^{69}$ The curves for complexes $\mathbf{C}_{\mathbf{4}}$ and $\mathbf{C}_{6}$ are shown in APPENDIX C. 


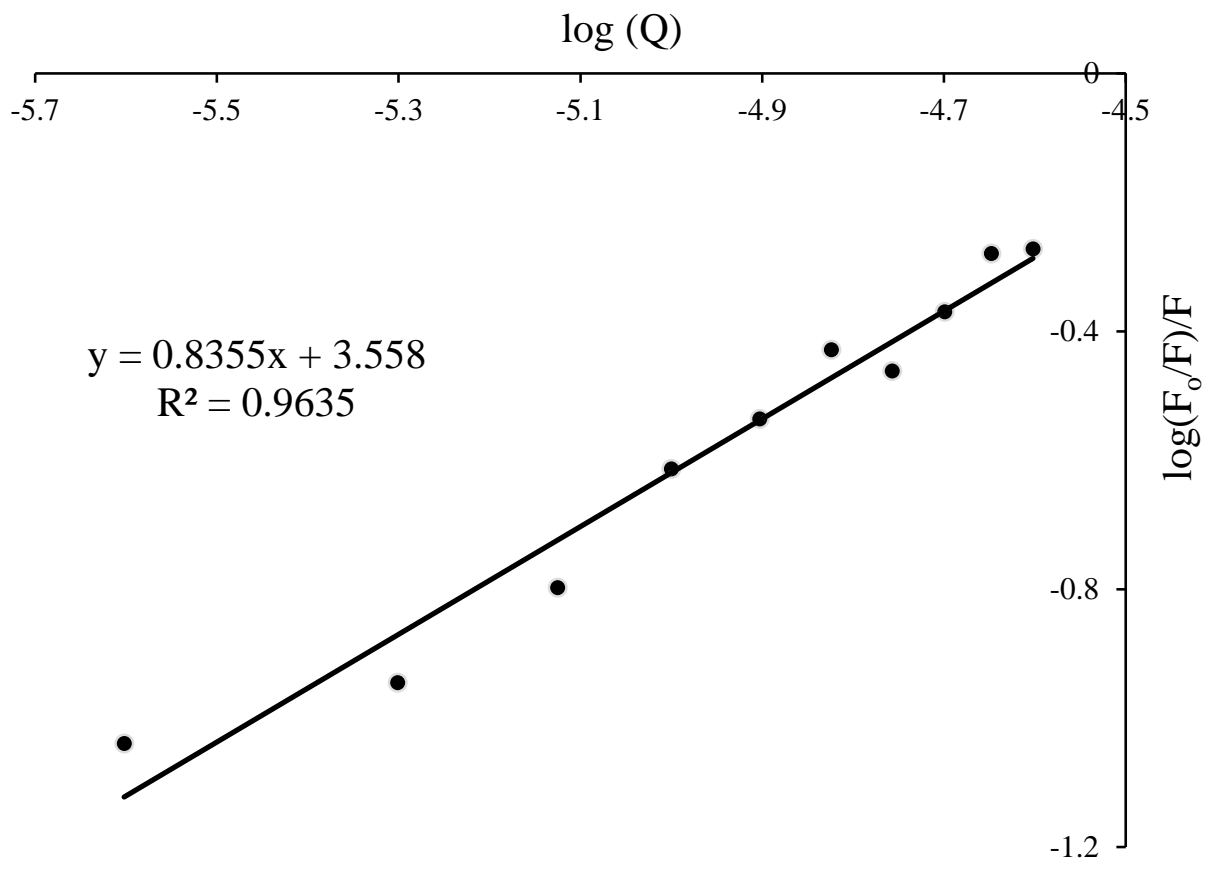

Figure 48. Modified Stern-Volmer plot for $\mathbf{C}_{2}$.

Table 2 summarizes the results of the interaction between complexes $\mathbf{C}_{\mathbf{2}}, \mathbf{C}_{\mathbf{4}}$ and $\mathbf{C}_{6}$.

\begin{tabular}{lcccc}
\hline Complex & $\mathrm{K}_{\mathrm{sv}}\left(10^{4} \mathrm{M}^{-1}\right)$ & $\mathrm{K}_{\mathrm{b}}\left(10^{3} \mathrm{M}^{-1}\right)$ & $\mathrm{K}_{\mathrm{q}}\left(10^{12} \mathrm{M}^{-1} \mathrm{~s}^{-1}\right)$ & $\mathrm{n}$ \\
\hline $\mathbf{C}_{2}$ & 2.1 & 3.6 & 2.1 & 0.83 \\
$\mathbf{C}_{4}$ & 4.1 & 12.2 & 4.1 & 0.89 \\
$\mathbf{C}_{6}$ & 4.1 & 12.2 & 4.1 & 0.89 \\
\hline
\end{tabular}

Table 2. Stern-Volmer quenching constant, $K_{\mathrm{sv}}$, Binding Constants, $\mathrm{K}_{\mathrm{b}}$ and number of binding sites $\mathrm{n}$ determined at $37^{\circ} \mathrm{C}$ and $\mathrm{pH} 7.4$

Complex $\mathbf{C}_{1}$ was not included presently due to inconsistencies in fluorescence quenching of HSA. The fluorescence intensities determined showed increased intensities in higher complex concentrations yielding a Stern-Volmer plot with coefficient of determination $\left(\mathrm{R}^{2}\right)$ of 0.946 . 


\section{Conclusion}

So far in this research work, six Schiff base ligands and four ruthenium(II) compounds have been synthesized. The binding studies of three out of the four ruthenium(II) compounds synthesized have been achieved. The Stern-Volmer quenching constant and the binding constant for the interaction between the complexes and HSA were found to be consistent with that already reported in literature. The bimolecular quenching constant also showed that, the quenching mechanism for the interaction between the complexes and HSA occurred through a static quenching mechanism.

In the future, efforts will be made to carry out further experiments to establish the standard deviation of the results of complexes $\mathbf{C}_{2} \mathbf{C}_{4}$ and $\mathbf{C}_{6}$ for the Stern-Volmer plots achieved so far. Additional experiment will evaluate other important drug properties, including the lipophilicity of the complexes and DNA interactions. The lipophilicity, which describes the ability of compounds to permeate cells would also be investigated to establish the ability of these compounds to enter cells. It is also anticipated that, the compounds would be tested against different cell lines including MCF-7 breast cancer and A2780 ovarian cancer cell lines which earlier piano-stool ruthenium(II) compounds have been tested against. This is to provide a comparative analysis of the efficacy of these compounds to already synthesized compounds such as RAPTA-C and RM175. Similar to RAPTA-C and RM175, the three compounds studied bind to HSA as shown in the fluorescence quenching of the tryptophan residue of HSA in this study. 


\section{REFERENCES}

1. World Health Organization. http://www.who.int/cancer/en/_(accessed October 22, 2018).

2. Aiyer, H. S. Warri, M. A.; Woode, R. D.; Hilakivi-Clarke, L.; Clarke, R., J. Agric. Food Chem., 2012, 60, 5693-5708.

3. Romero-Canelón, I.; Sadler, P. J. Inorg. Chem. 2013, 52, 12276-12291.

4. Chu, Y-H.; Sibrian-Vazquez, M.; Escobedo, O. J.; Phillips, A. R.; Thomas D.; Wang Q.; Ralle, M.; Steyger P. S.; Strongin, M. R. Molec. Pharm. 2016, 13, 2677-2682.

5. Wilson, J. J.; Lippard J. S. Chem. Rev. 2014, 114, 4470-4495.

6. Geng, J.; Aioub, M.; El-Sayed, A. M. Barry, B. A. J. Phys. Chem. B 2017, 121, 8975-8983.

7. Nguyen, T. H.; Arnesano, F.; Scintilla, S.; Rossetti, G.; Ippoliti, E.; Carloni, P.; Natile, G. J. Chem. Theory Comput. 2012, 8, 2912-2920.

8. Testicular cancer. www.cancercenter.com (accessed December 7, 2018)

9. Reedijk, J. Pt Met Rev, 2008, 52, 2-11.

10. Zhang, X.; Zhang, S.; Zhu, S.; Chen, S.; Han, J.; Gao, K.; Zeng, J-Z; Yan, X. Anal. Chem. 2014, 86, 5232-5237.

11. Johnstone, C.; T.; Suntharalingam, K.; Lippard, S. J. Chem. Rev. 2016, 116, 3436-3486.

12. Cheung-Ong, K.; Song, K. T.; Ma, Z.; Shabtai D.; Lee, A. Y.; Gallo, D.; Heisler, L. E.; Brown, G. W.; Bierbach, U.; Giaever, G; Nislow, C. ACS Chem. Bio. 2012, 7, 18921901.

13. Johnstone, C. T.; Wilson, J. J.; Lippard, S. J. Inorg. Chem. 2013, 52, 12234-12249.

14. Aman, F. Hanif, M. Siddiqui, A. W.; Ashraf, A.; Filak L. K., Reynisson, J.' Söhnel, T.; Jamieson, S. M. F.; Hartinger, C. G. Organometallics 2014, 33, 5546-5553. 
15. Gossens, C.; Tavernelli, I; Rothlisberger. U. J. Am. Chem. Soc. 2008, 130, 10921-10928.

16. Chin, C. F.; Tian, Q.; Setyawati, M. I. Fang, W.; Tan, E. S. Q.; Leong, D. T. Ang. W. H. J. Med. Chem. 2012, 55, 7571-7582.

17. Pal, M.; Nandi, U.; Mukherje, D. Eur. J. Med. Chem. 2018, 150, 419 - 445.

18. Casini, A.; Mastrobuoni, G.; Terenghi, M.; Gabbiani, C.; Monzani, E.; Moneti G.; Casella, L.; Messori, L. J Biol. Inorg. Chem. 2007, 12, 1107-1117.

19. Biancalana, L.; Batchelor, L. K.; Funaioli, T.; Zacchini, S.; Pampaloni, B G.; Dyson, P. J.; Marchetti, F. Inorg. Chem. 2018, 57, 6669-6685.

20. Gasser, G.; Ott, I.; Metzler-Nolte, N. J. Med. Chem. 2011, 54, 3-25.

21. Allardyce; S. C.; Dyson, P. J. Platium Metals Rev. 2001, 45, 62- 49.

22. DNA Intercalators. nptel.ac.in/courses. (accessed December 13, 2018)

23. Suss-Fink, G. Dalton Trans. 2010, 39, 1673-1688.

24. Webb, M. I.; Wu, B; Jang, T; Chard, R. A.; Wong, E. W.; Wong, M. Q; Yapp, D. T.; Walsby, C. J. Chem. Eur. J. 2013, 19, 17031-17042

25. Smithen, A. D.; Yin, H.; Beh, M. H. H.; Hetu, M.; Cameron, S. T.; McFarland, S. A.; Thompson, A. Inorg. Chem. 2017, 56, 4121-4132.

26. Guo, W.; Zheng, W.; Luo, Q.; Li, X.; Zhao, Y.; Xiong, S.; Wang, F. Inorg. Chem. 2013, $52,5328-5338$.

27. Du, Q.; Guo, L.; Tian, M. Ge, X.; Yang, Y.; Jian, X.; Xu, Z.; Tian, Z.; Liu, Z. Organomet. 2018, 37, 2880-2889.

28. Debreczeni, J. E.; Bullock, N. A. G.; Atilla, E.; Williams, D. S.; Bregman, H.; Stefan K., Meggers, E. Angew. Chem. Int. Ed. 2006, 45,1580-1585.

29. Vock, C. A.; Ang, W. H.; Scolaro, C.; Phillips, A. D.; Lagopoulos, L.; JuilleratJeanneret, L. Sava, G.; Scopelliti, R.; Dyson, P. J. J. Med. Chem. 2007, 50, 2166-2175. 
30. Levina, A.; Mitra, A; Lay, P. A. Metallomics, 2009, 1, 458-470.

31. Nieto, D.; Bruñ, S.; Gonzalez-Vadillo, A. M.; Josefina Perles, J.; Carrillo-Hermosilla, F.; Antiñolo, A.; Padron, J. M.; Plata, G. B.; Cuadrado, I. Org. 2015, 34, 5407-5417.

32. Zeng, L.; Gupta, P.; Chen, Y.; Wang, E.; Ji, L.; Chao, H.; Chen. Z.-S. Chem. Soc. Rev., 2017, 46, 5771 .

33. Kajal, A. Bala, S., Kamboj, S., Sharma, S. Vipin, S. J. of Cat. 2013, 1-14

34. Da Silva, C. M.; da Silva, L. D.; Modolo, L. V.; Alves, B. R.; de Resende, M. A., Martins, C. V. B.; de Fa'tima, A. J. Adv. Res. 2011, 2 1-8.

35. León, I. E.; Cadavid-Vargas, J. F.; Virgilio, A. L. D.; Etcheverry, S. B. Curr. Med. Chem, 2017, 24, 112-148.

36. Nair, S. M., D., Johnson, A. J. J. of Saudi Chem. Soc. 2016, 20, S591-S598.

37. Dong, Y.-W.; Fan, Q.-R.; Wang, X.-M.; Wang, P.; Zang, J.-H.; Wei, L.-G.; Song, Y.; Du, X.; Chen, W.; Yang, Y.-L. Eur. J. Inorg. Chem. 2016, 3598-3610

38. Nyamori, V. O.; Keru, G.; Omondi, B. Acta Cryst. 2012, 68, 1535.

39. Hess, J. Patra, M. Pierroz, V., Spingler, B., Jabbar, A., Ferrari, S., Gasser, R. B., Gasser, G. Organmet. 2016, 35, 3369-3377.

40. Goggins, S; Apsey, E. A.; Mahon, M. F.; Frost, C. G. Org. Biomol. Chem., 2017, 15, 2459.

41. Chow, M. J.; Licona, C.; Wong, D. Y. Q.; Pastorin, G.; Gaiddon, C.; Ang, W. H. J. Med. Chem. 2014, 57, 6043-6059.

42. Zeng, L.; Gupta, P.; Chen, Y.; Wang,E.; Ji, L.; Chao, H.; Zhe-Sheng Chen, Z-S. Chem Soc Rev. 2017, 46 5771-5804.

43. Suss-Fink, G. Dalton Trans. 2010, 39, 1673-1678. 
44. J. R. Durig, J. Danneman, W. D. Behnke and E. E. Mercer, Chem.- Biol. Interact. 1976, $13,287$.

45. M. J. Clarke, Met. Ions Biol. Syst., 1980, 11, 231.

46. M. J. Clarke, F. Zhu; D. R. Frasca, Chem. Rev. 1999, 99, 2511.

47. Motswainyana, W. M.; Ajibade, P. A. Adv. in Chem. 2015, 1-22.

48. Coverdale, J. P. C.; Laroiya-McCarron, T.; Romero-Canelón, I. Inorg. 2019, 7, 31.

49. Allardyce, C. S.; Dyson, P. J.; Ellis, D. J.; Heath, S. L. Chem. Commun. 2001, 2, 13961397.

50. Murray, B.S.; Babak, M.V.; Hartinger, C.G.; Dyson, P.J. Coord. Chem. Rev. 2016, 306, 86-114

51. Phillips, A.D.; Gonsalvi, L.; Romerosa, A.; Vizza, F.; Peruzzini, M. Coord. Chem. Rev. 2004, 248, 955-993.

52. Scolaro, C.; Bergamo, A.; Brescacin, L.; Delfino, R.; Cocchietto, M.; Laurenczy, G.; Geldbach, T. J.; Sava, G.; Dyson, P. J. J. Med. Chem. 2005, 48, 4161- 4171.

53. Weiss, A; Ding, X.; van Beijnum, J. R.; Wong, I; Wong, T. J.; Berndsen, R. H.; Dormond, O.; · Dallinga, M.; Shen, L.; Schlingemann, S.; Pili, R.; Ho, C-M.; Dyson, P. J.; van den Bergh, H.; Griffioen, A. W.; Nowak-Sliwinska, P. Ang. 2015, 18, 233-244.

54. Kessenbrock, K.; Plaks, V.; Werb, Z. Cell 2010, 141, 52-67.

55. Morris, R. E.; Aird, R. E.; Murdoch, P. D. S.; Chen, H.; Cummings, J.; Hughes, N.D.; Parsons, S.; Parkin, A.; Boyd, G.; Jodrell, D.I.; Sadler, P. J.; J. Med. Chem. 2001, 44, $3616-3621$.

56. Carter, R.;Westhorpe, A.; Romero, M.J.; Habtemariam, A.; Gallevo, C.R.; Bark, Y.; Menezes, N.; Sadler, P.J.; Sharma, R.A. Sci. Rep. 2016, 6, 1-12. 
57. Bergamo, A.; Masi, A.; Peacock, A. F. A.; Habtemariam, A.; Sadler, P.J.; Sava, G. J. Inorg. Biochem. 2010, 104, 79-86.

58. Ding, F.; Diao, J.-X. Sun, Y.; Sun. Y.; J. Agric. Food Chem. 2012, 60, 7218-722.

59. Yue, J.; Liu, S.; Wang, R.; Hu, X.; Xie, Z.; Huang, Y.; Xiabin, J. Mol. Pharmaceutics 2012, 9, 1919-1931.

60. Lai, S. H.; Li, W.; Yao, J. H.; Han, B. J.; Jiang, G. B.; Zhang, C.; Zeng, C. C.; Liu, Y. J. J. Photochem. Photobiol., 2016, 158, 39-48.

61. Čanović, P.; Simović, A. R.; Radisavljević, S.; Bratsos, I.; Demitri, N.; Mitrović, M.;

62. Zelen, I.; Bugarčić, Z. D. J. Biol. Inorg. Chem. 2017, 22, 1007-1028.

63. Casini, A.; Gabbiani, C.; Sorrentino, F.; Rigobello, M. P.; Bindoli, A.; Geldbach, T. J.; Marrone, A.; R, N.; Hartinger, C. G.; Dyson, P. J.; Messori, L. J. Med. Chem. 2008, 51, $6773-6781$.

64. Cacita, N.; Nikolaou, S. J. Lumin. 2016, 169, 115-120.

65. Lucas, H. L.: Price, K. E.; Cynthia K. Larive, C. K. J. Am. Chem. Soc. 2004, 126, $14258-14266$.

66. Sugio, S.; Kashima, A.; Mochuziki, S.; Noda, M.; Kobayashi, K. Prot. Eng. 1999, 12, 439-446.

67. Osama K. Abou-Zied. O. K.; Al-Shihi, O. I. K. J. Am. Chem. Soc. 2008, 130, 1079310801. 


\section{APPENDIX A: SUPPLEMENTARY DATA OF CHAPTER TWO}

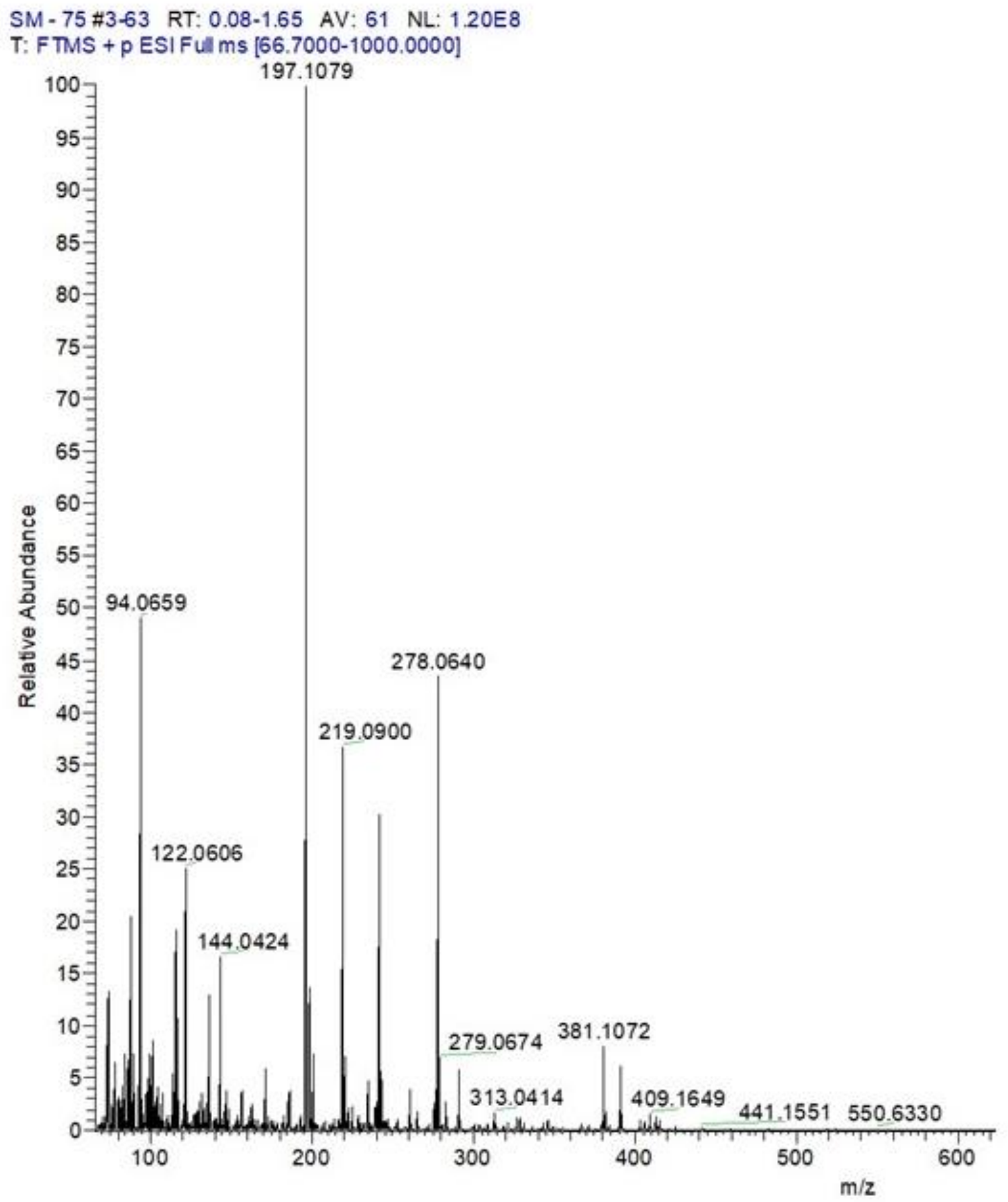

Figure A1. Positive mode ESI-HRMS data for ligand L1. 


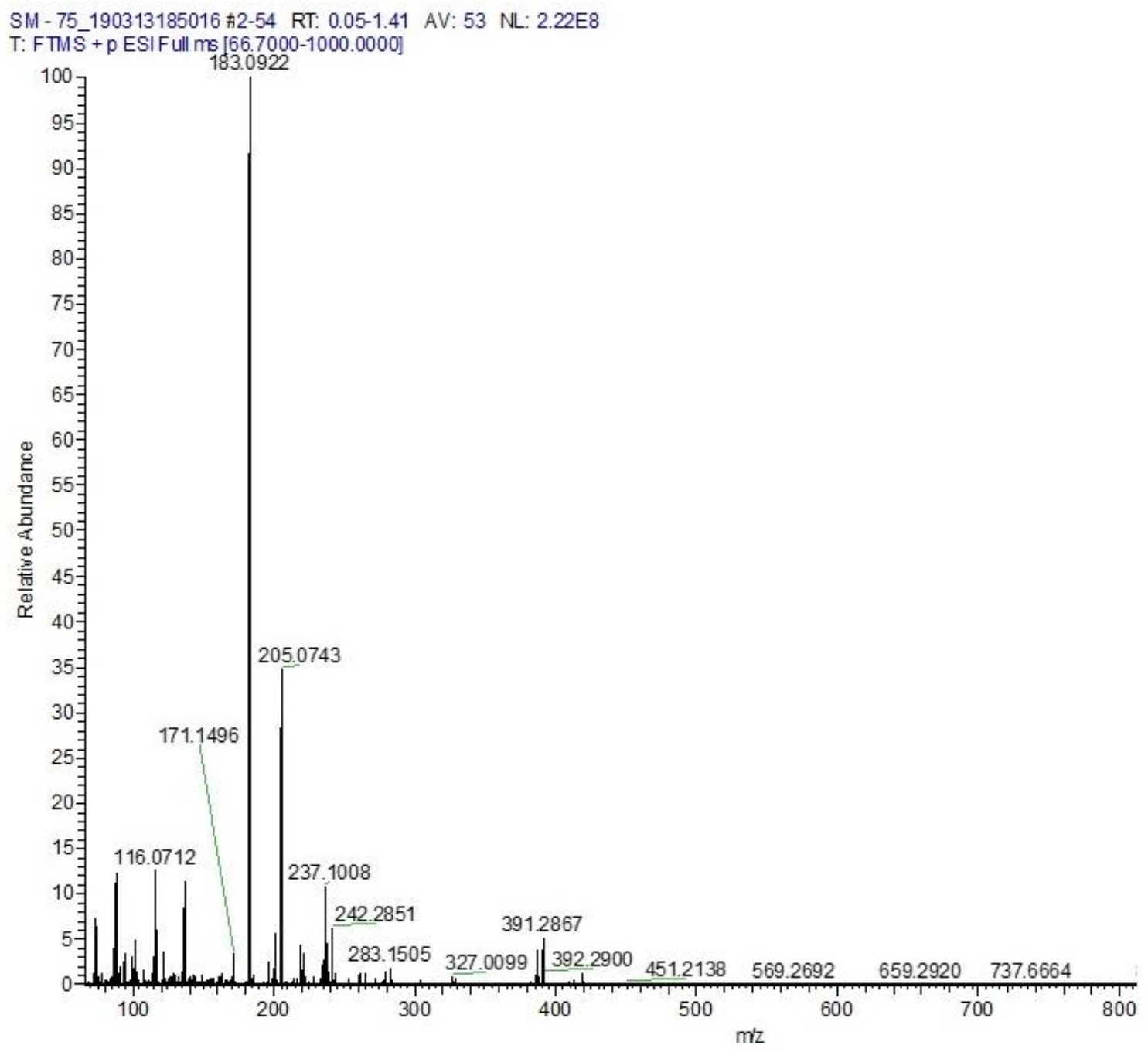

Figure A2. Positive mode ESI-HRMS data for ligand L2. 


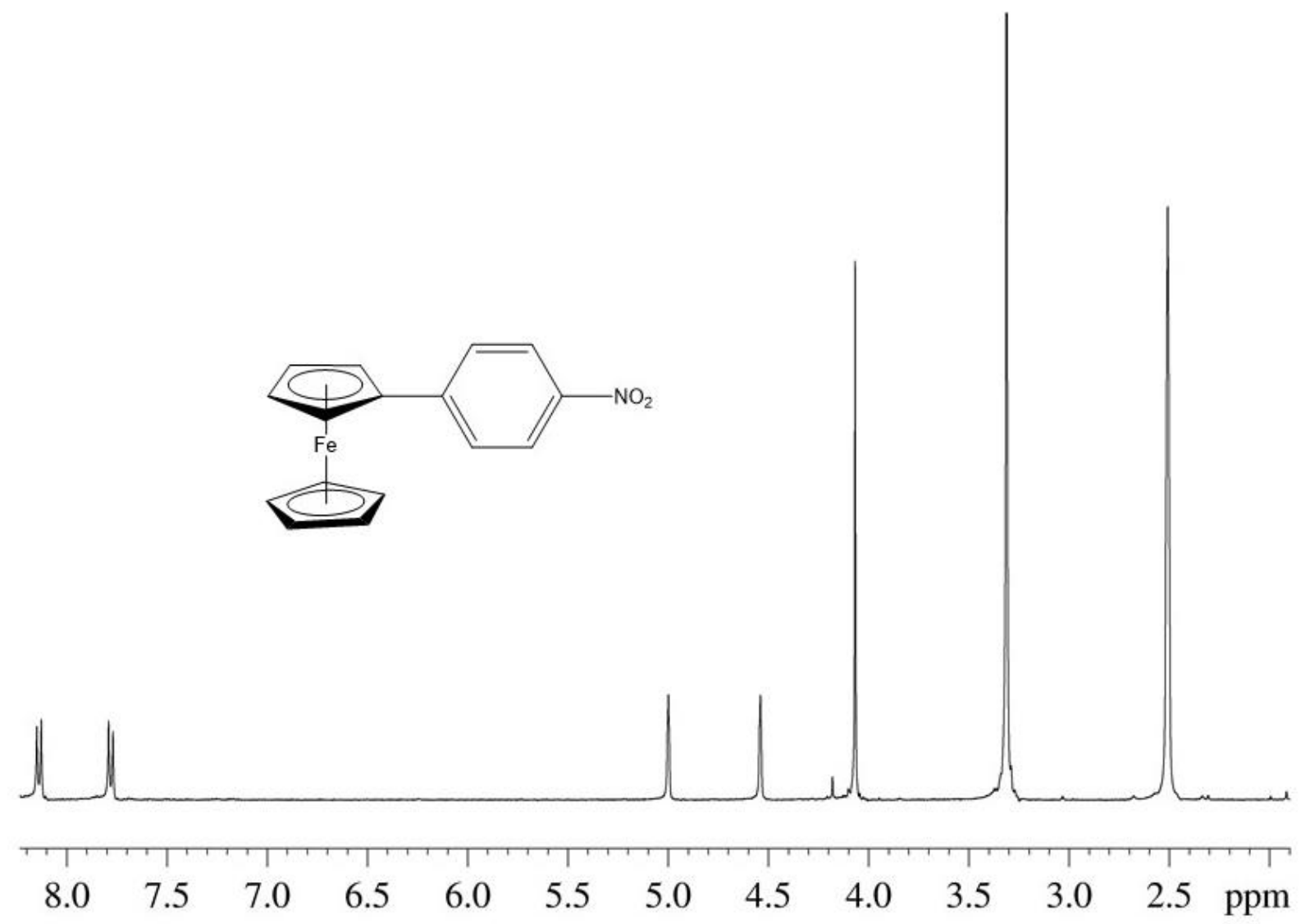

Figure A3. ${ }^{1} \mathrm{H}$ NMR spectrum of 4-nitrophenylferrocene in DMSO-d 6 . 


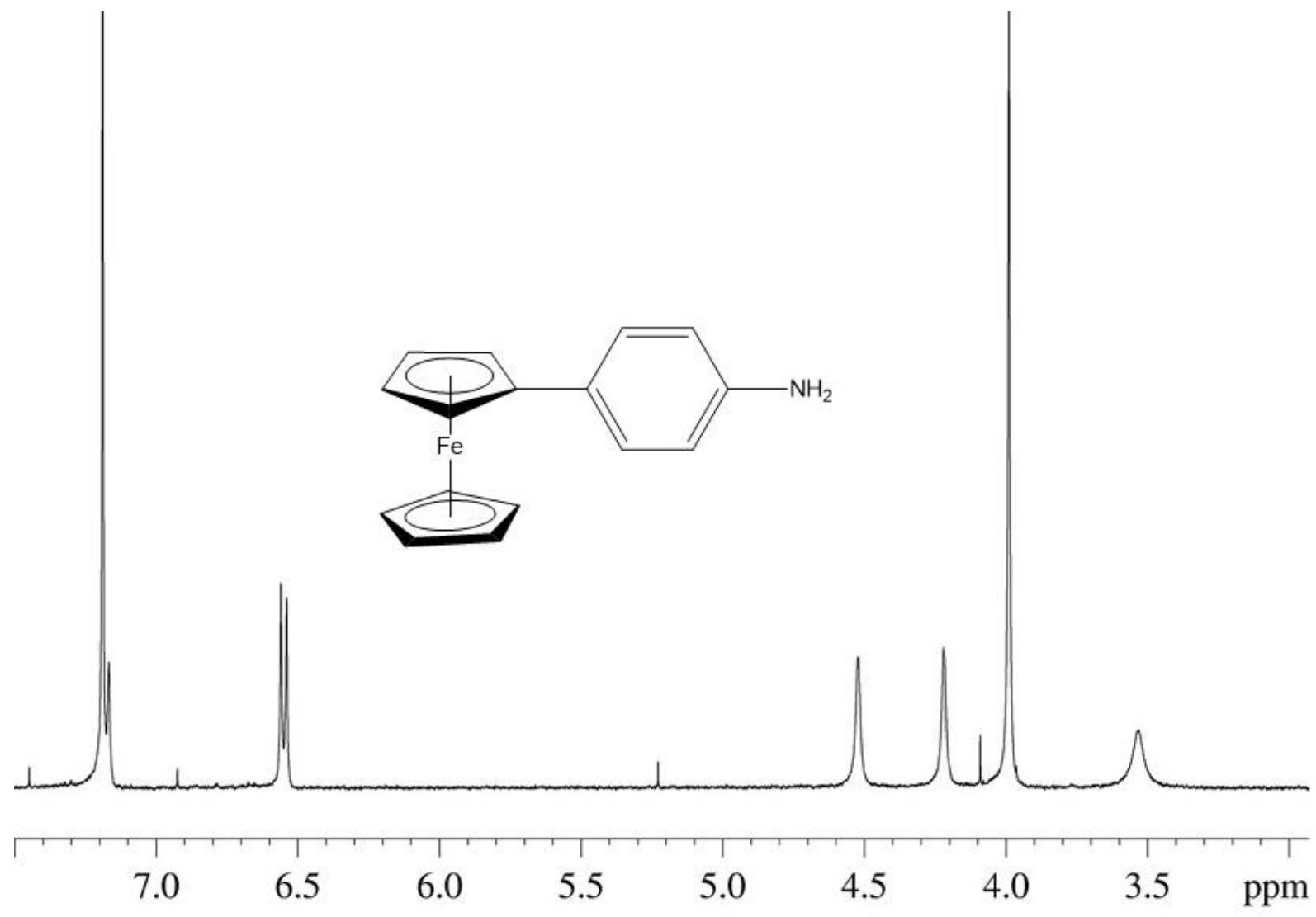

Figure A4. ${ }^{1} \mathrm{H}$ NMR spectrum of 4-ferrocenylaniline in $\mathrm{CDCl}_{3}$. 


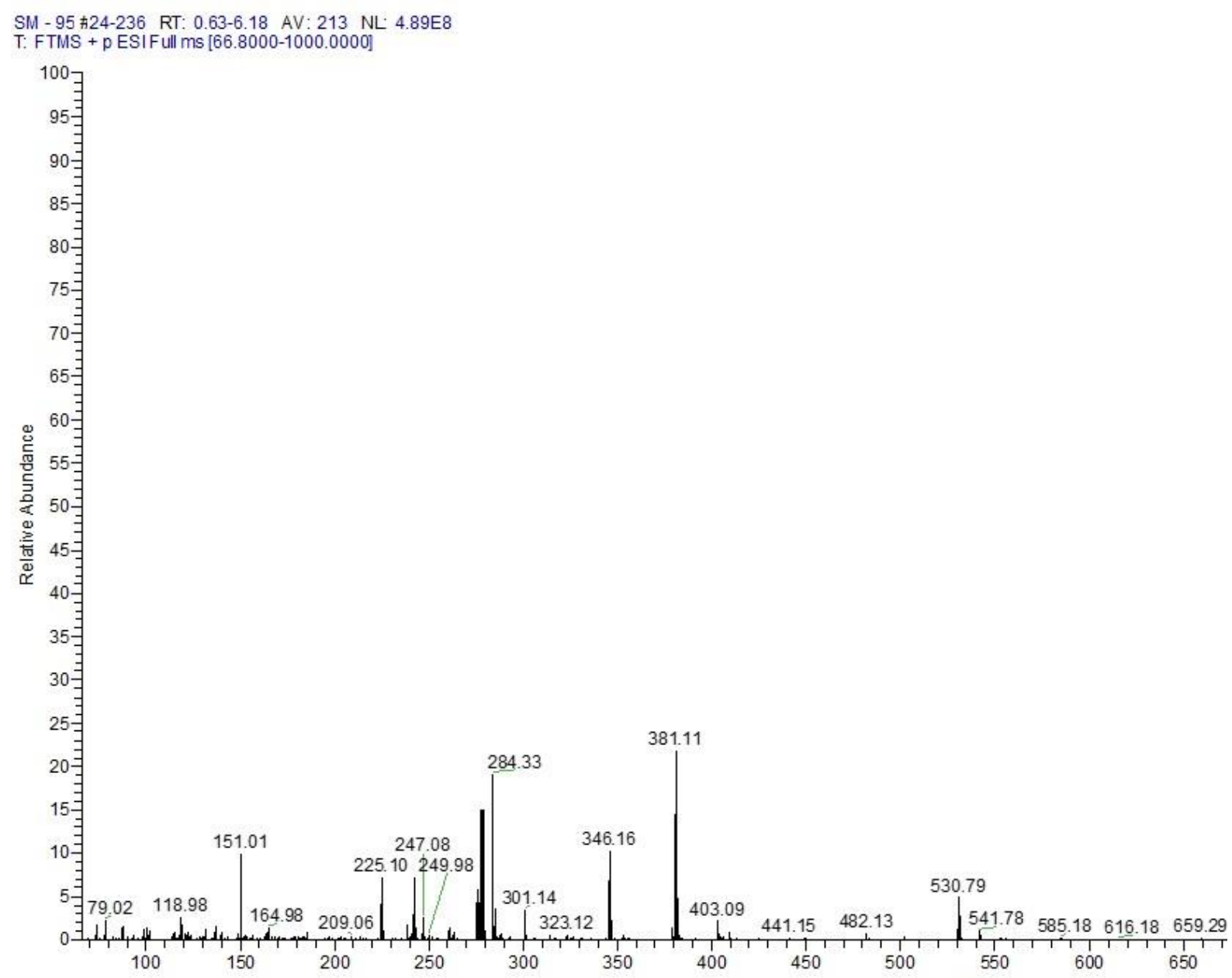

Figure A5. Positive mode ESI-HRMS spectrum of L3. 


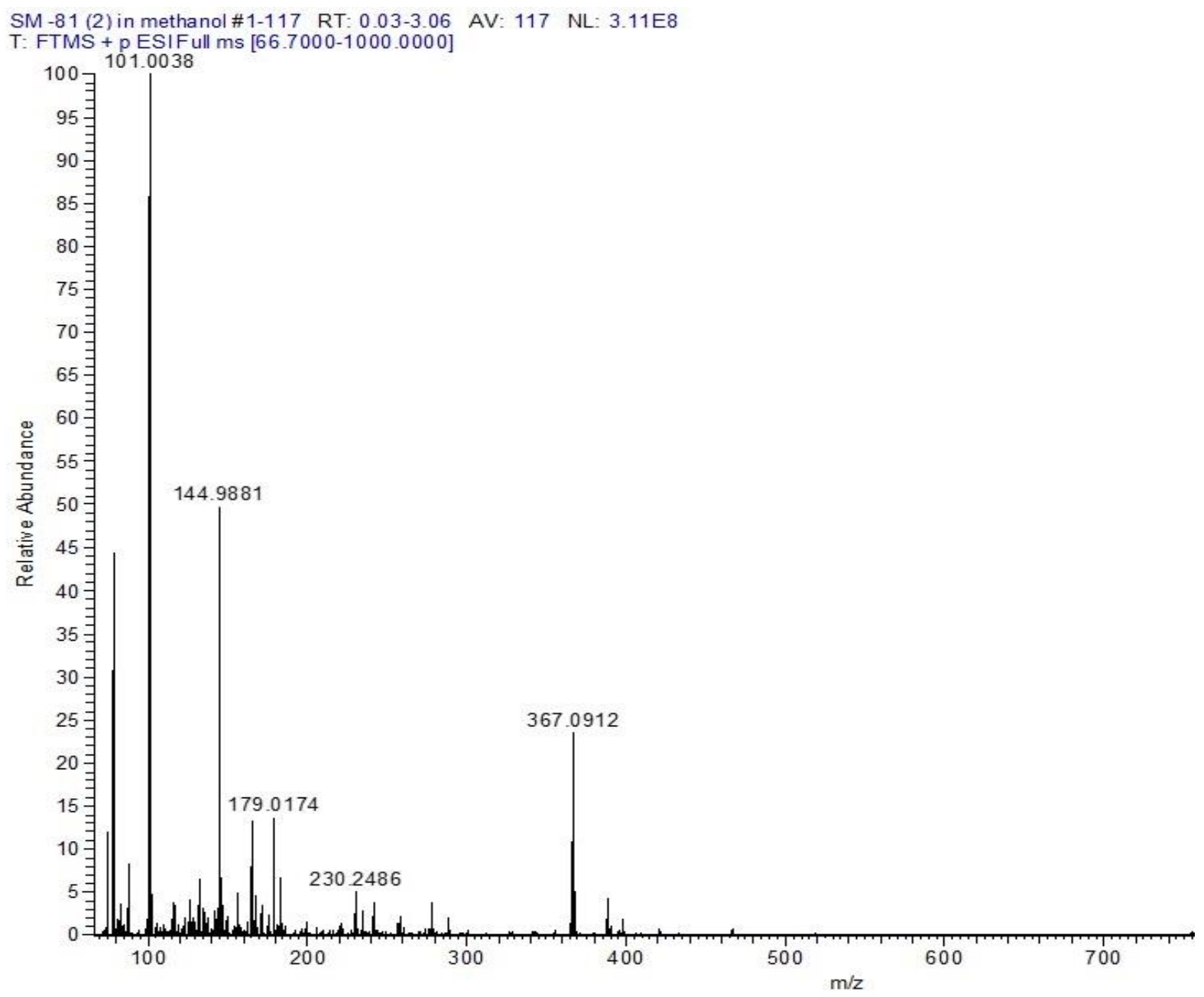

Figure A6. Positive mode ESI-HRMS spectrum of L4. 


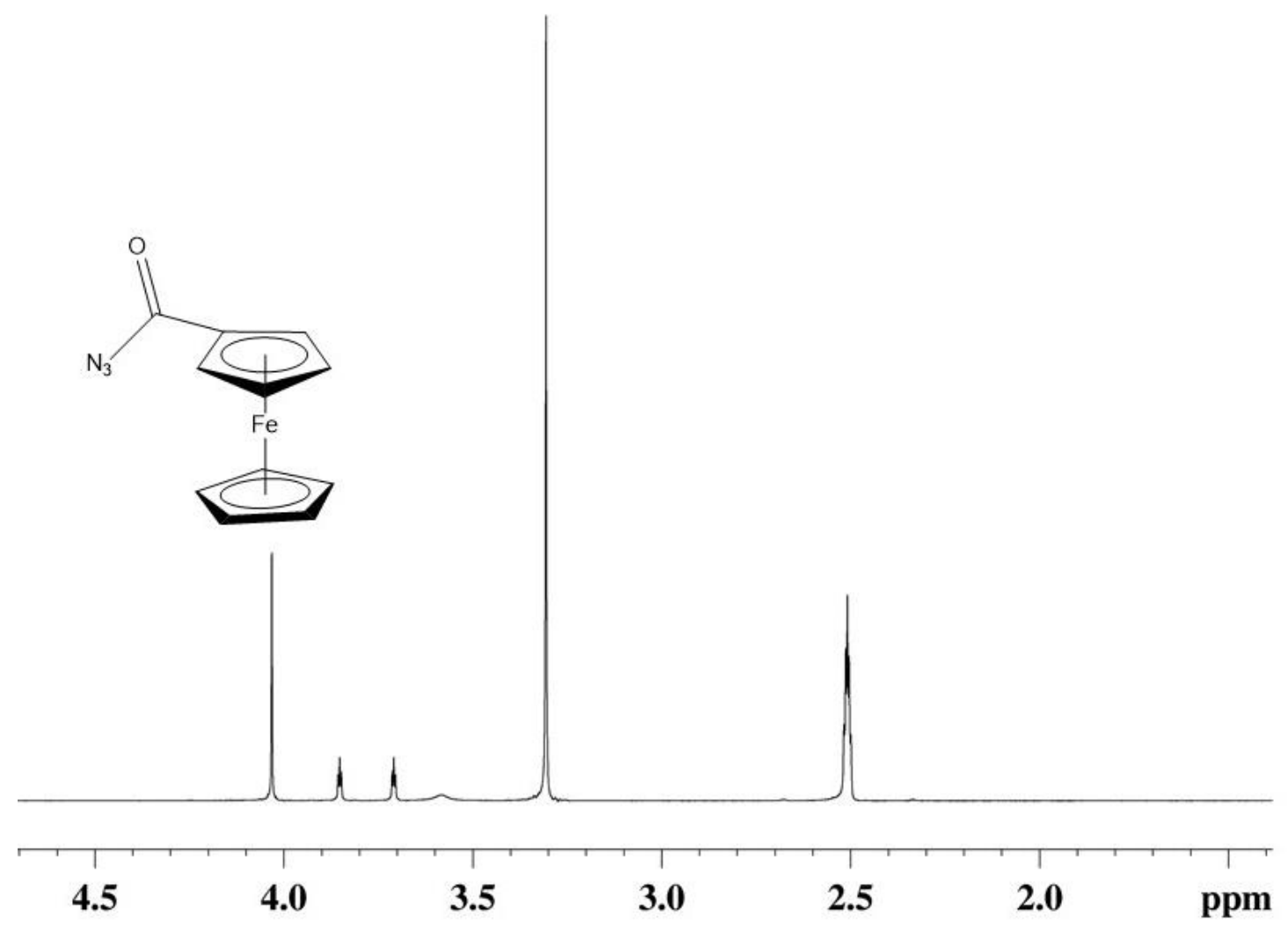

Figure A7. ${ }^{1} \mathrm{H}$ NMR spectrum of ferrocenoyl azide in DMSO-d 6 . 


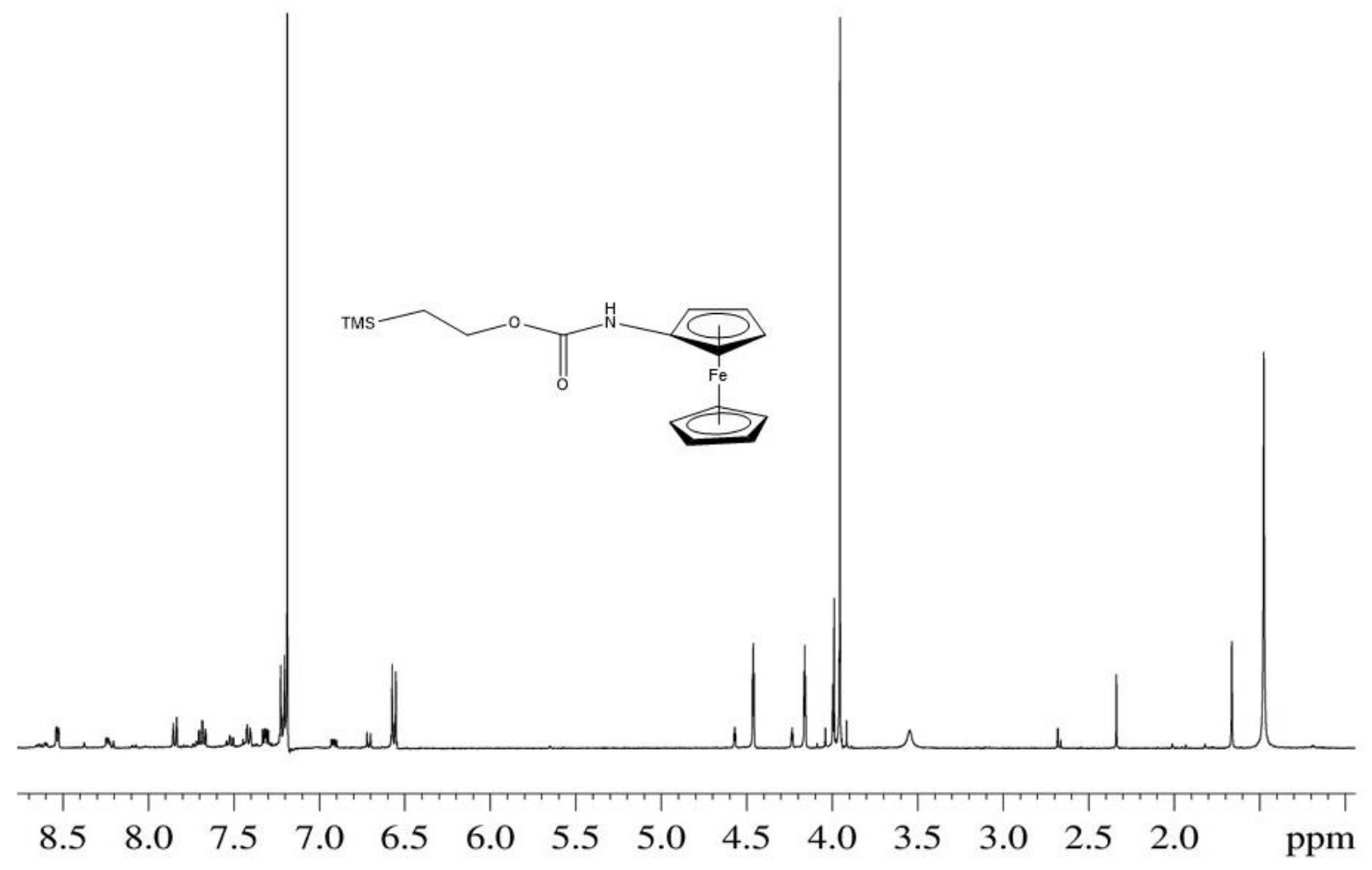

Figure A8. ${ }^{1} \mathrm{H}$ NMR spectrum of 2-(trimethylsilyl)ethylferrocenylcarbamate in $\mathrm{CDCl}_{3}$.

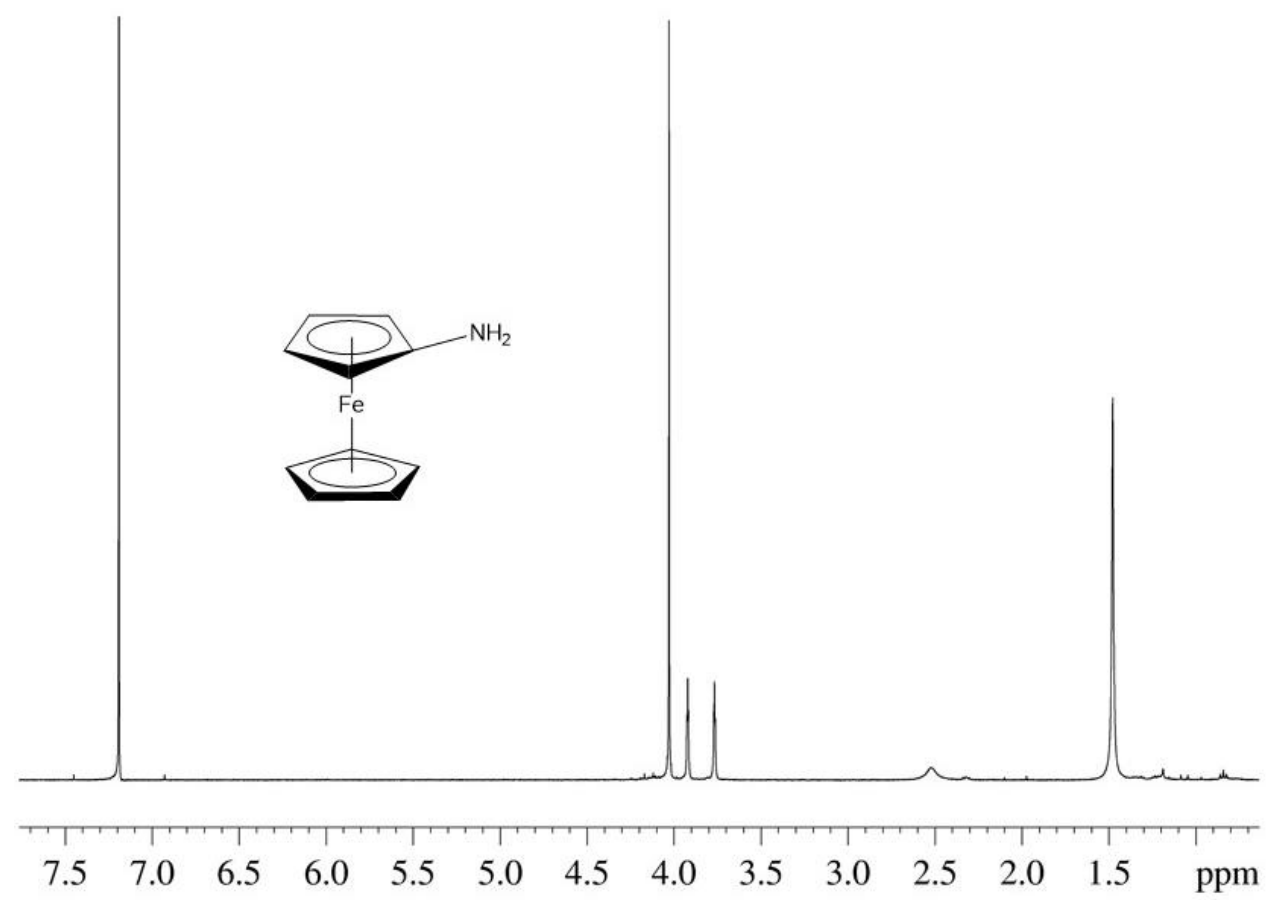

Figure A9. ${ }^{1} \mathrm{H}$ NMR Spectrum of a minoferrocene in $\mathrm{CDCl}_{3}$. 


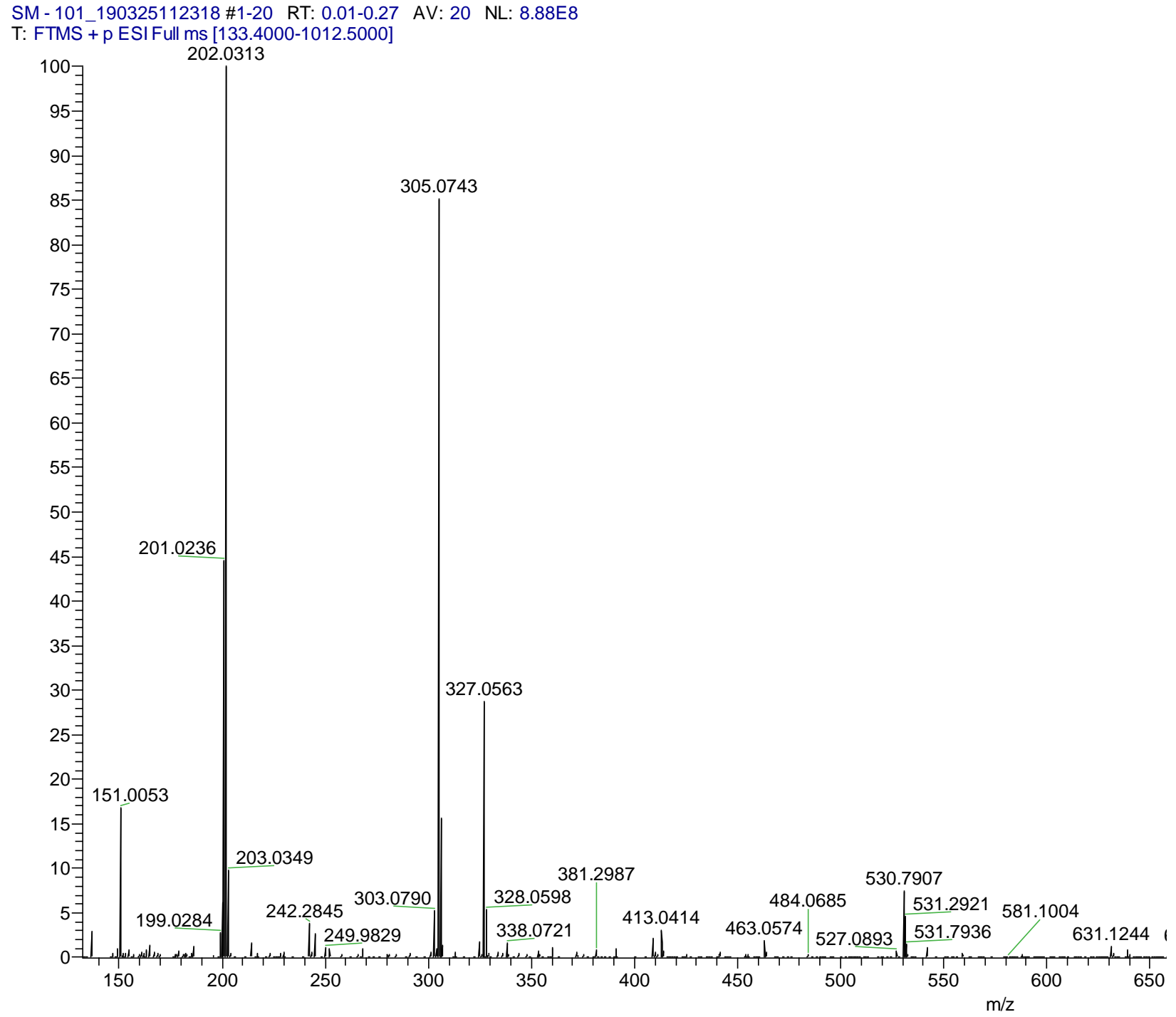

Figure A10. Positive mode ESI-HRMS spectrum of L5. 


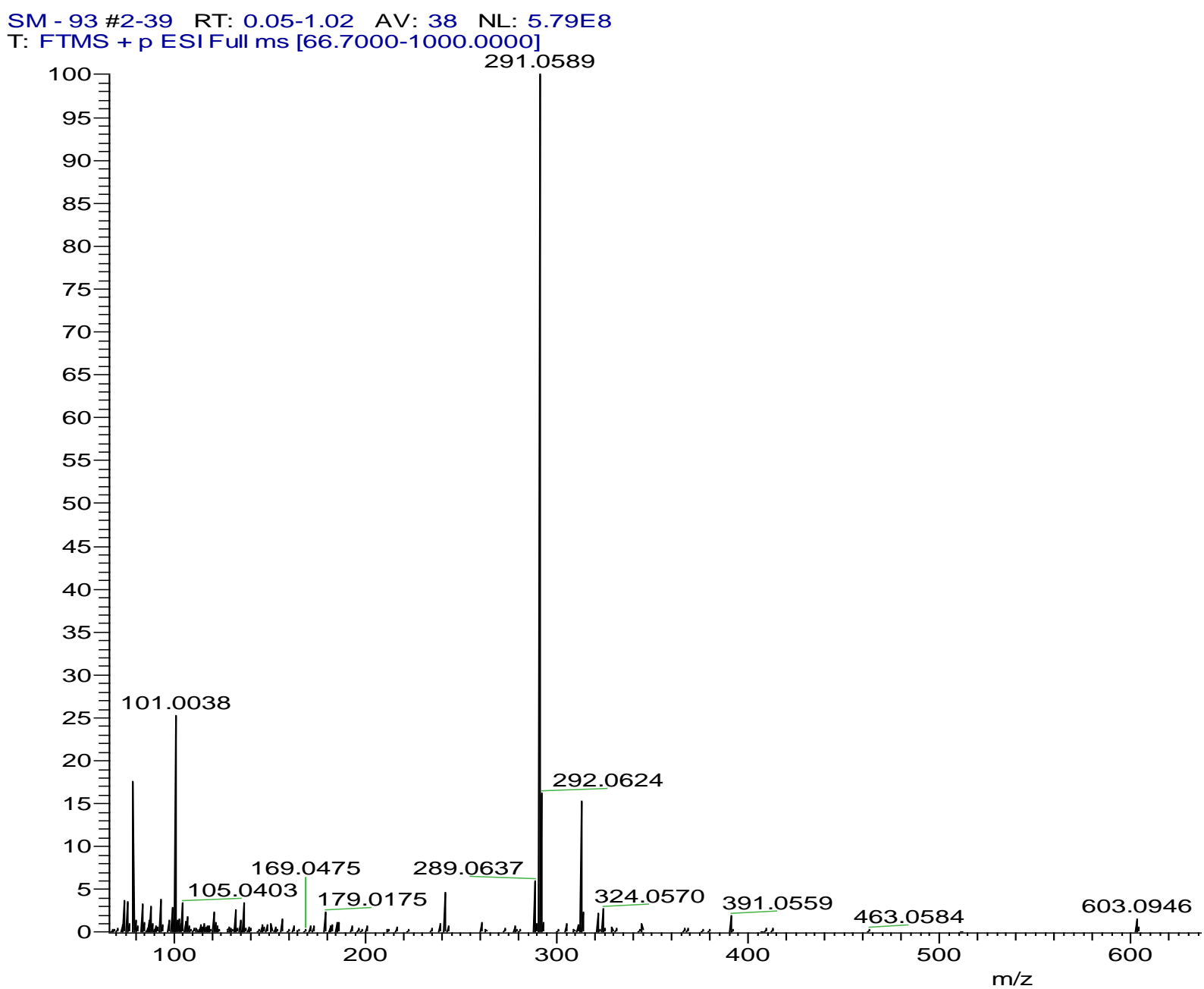

Figure A11. Positive mode ESI-HRMS spectrum of L6. 


\section{APPENDIX B: SUPPLEMENTARY DATA OF CHAPTER THREE}

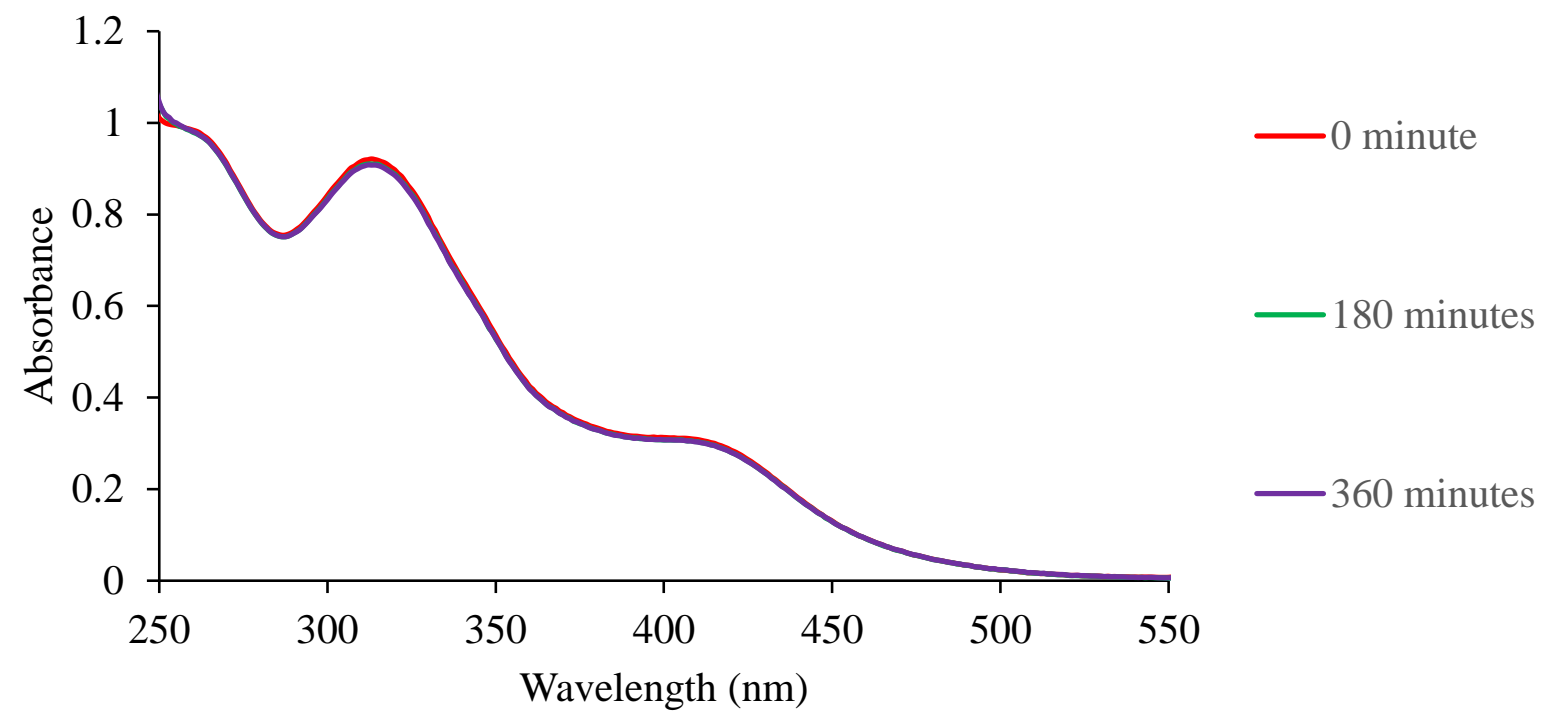

Figure B1. UV-vis spectrum of $100 \mu \mathrm{M} \mathbf{C}_{2}$ in $10 \%$ DMSO and PBS(aq) at pH 7.4 and temperature of $37^{\circ} \mathrm{C}$.

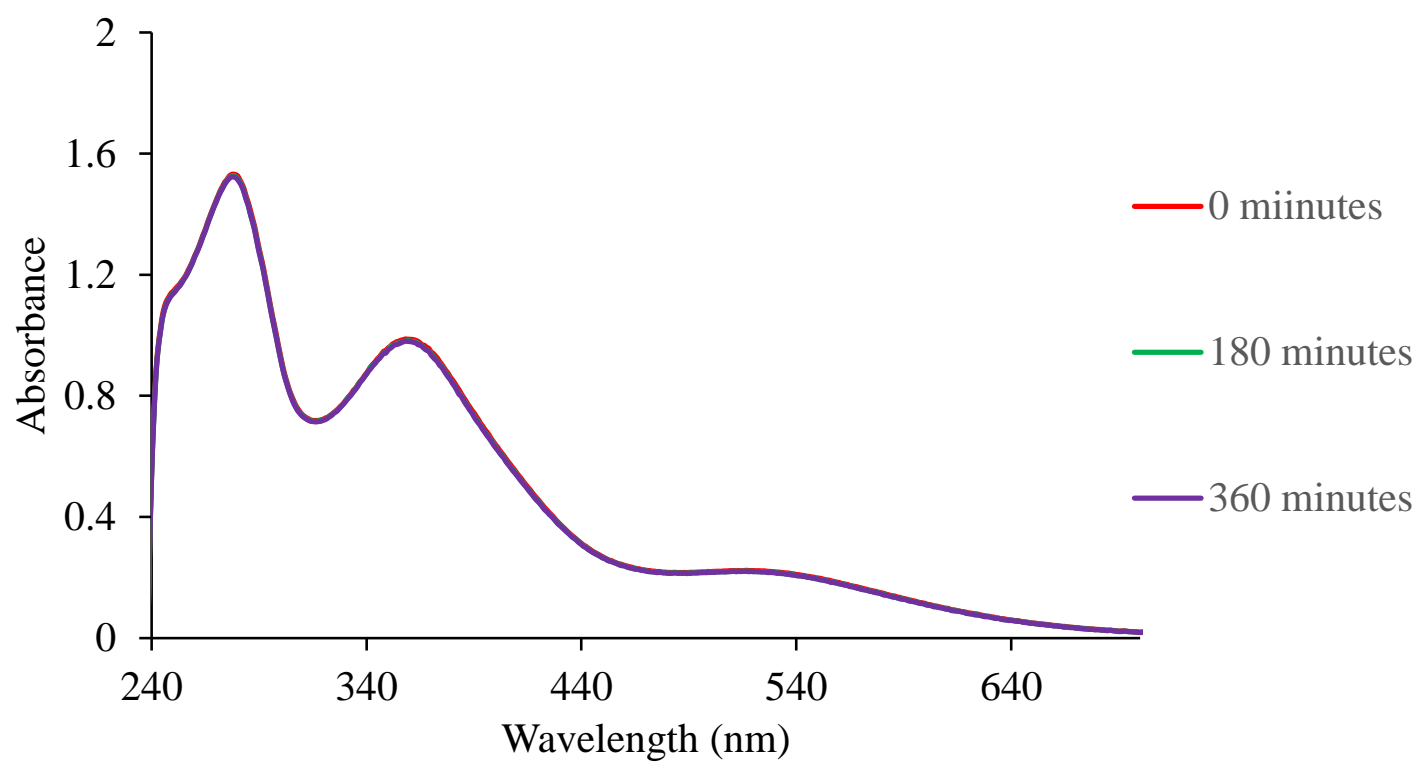

Figure B2. UV-vis spectrum of $100 \mu \mathrm{M} \mathbf{C}_{4}$ in $10 \%$ DMSO and PBS(aq) at pH 7.4 and temperature of $37^{\circ} \mathrm{C}$. 


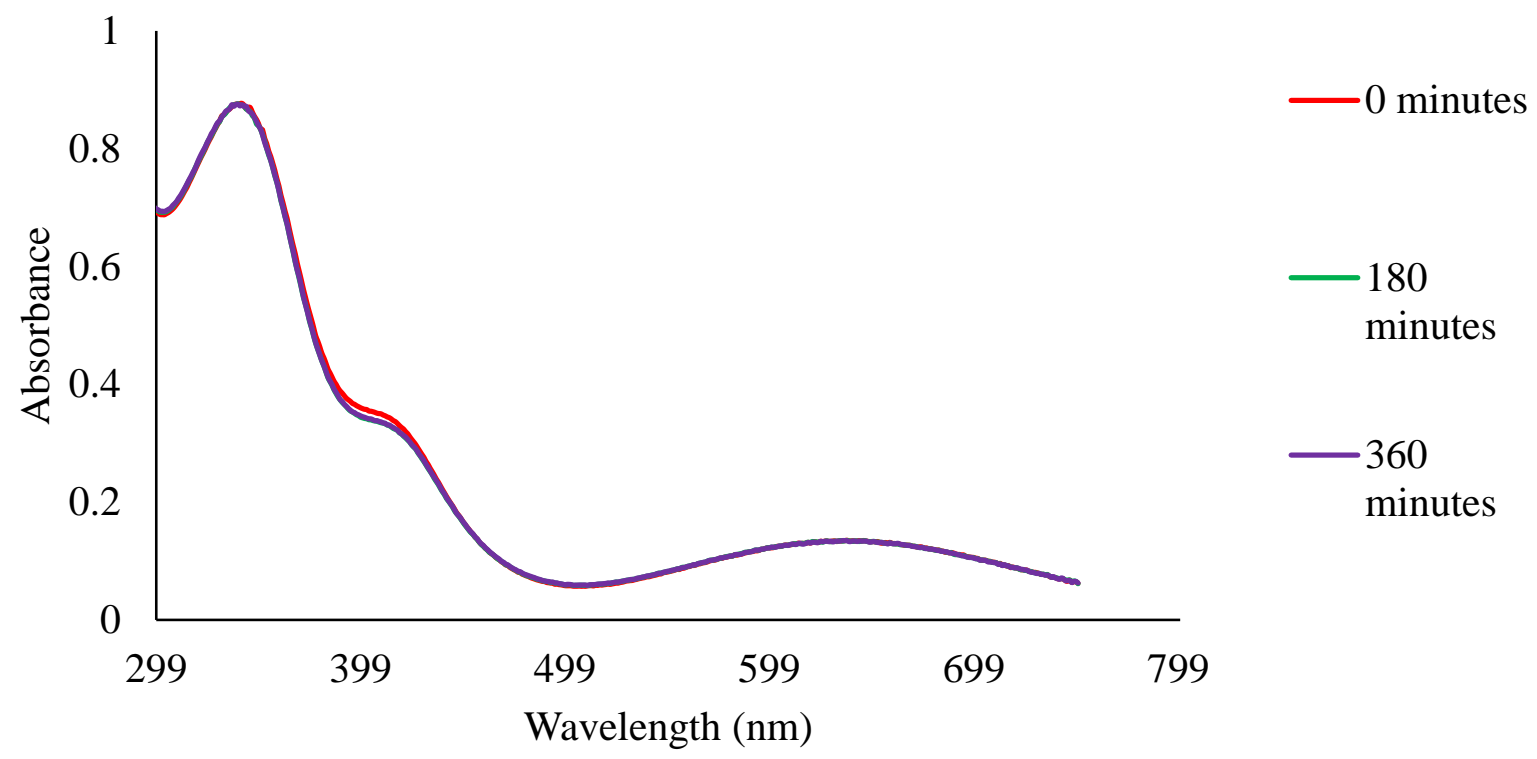

Figure B3. UV-vis spectrum of $100 \mu \mathrm{M} \mathbf{C}_{6}$ in $10 \%$ DMSO and PBS(aq) at pH 7.4 and temperature of $37^{\circ} \mathrm{C}$. 


\section{APPENDIX C: SUPPLEMENTARY DATA OF CHAPTER FOUR}

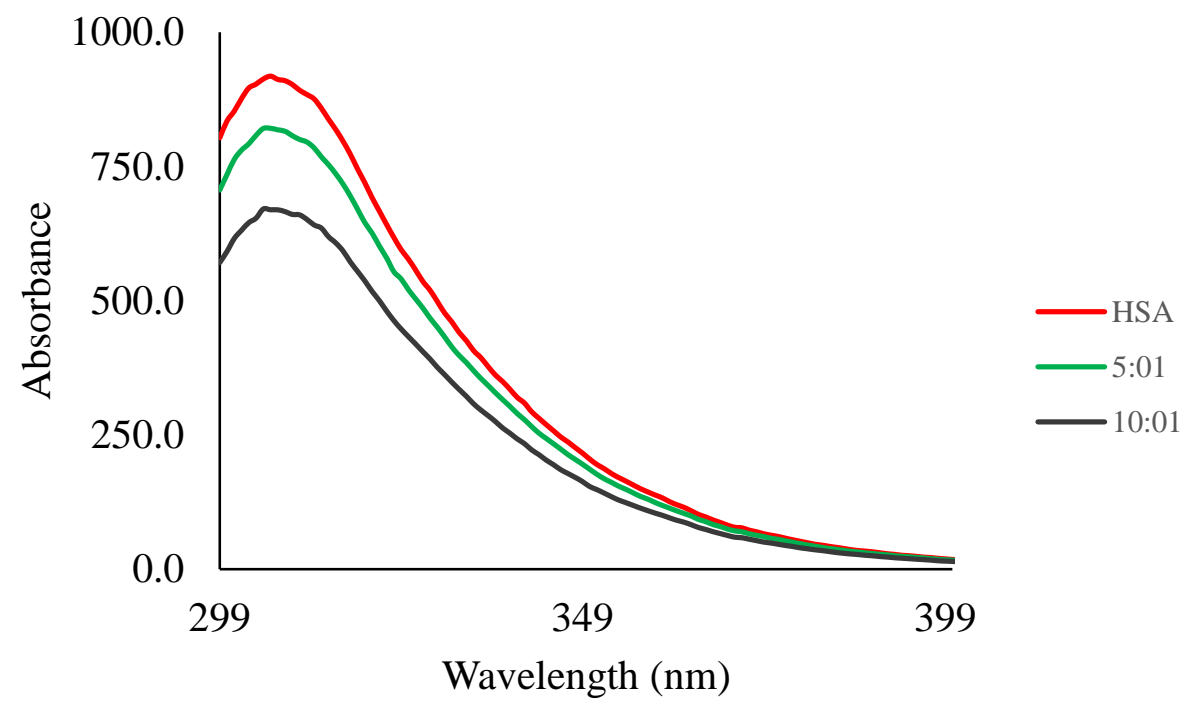

Figure C1. HSA fluorescence quenching by $\mathbf{C}_{1}$ at $37{ }^{\circ} \mathrm{C}$ and $\mathrm{pH}$ of 7.4. 


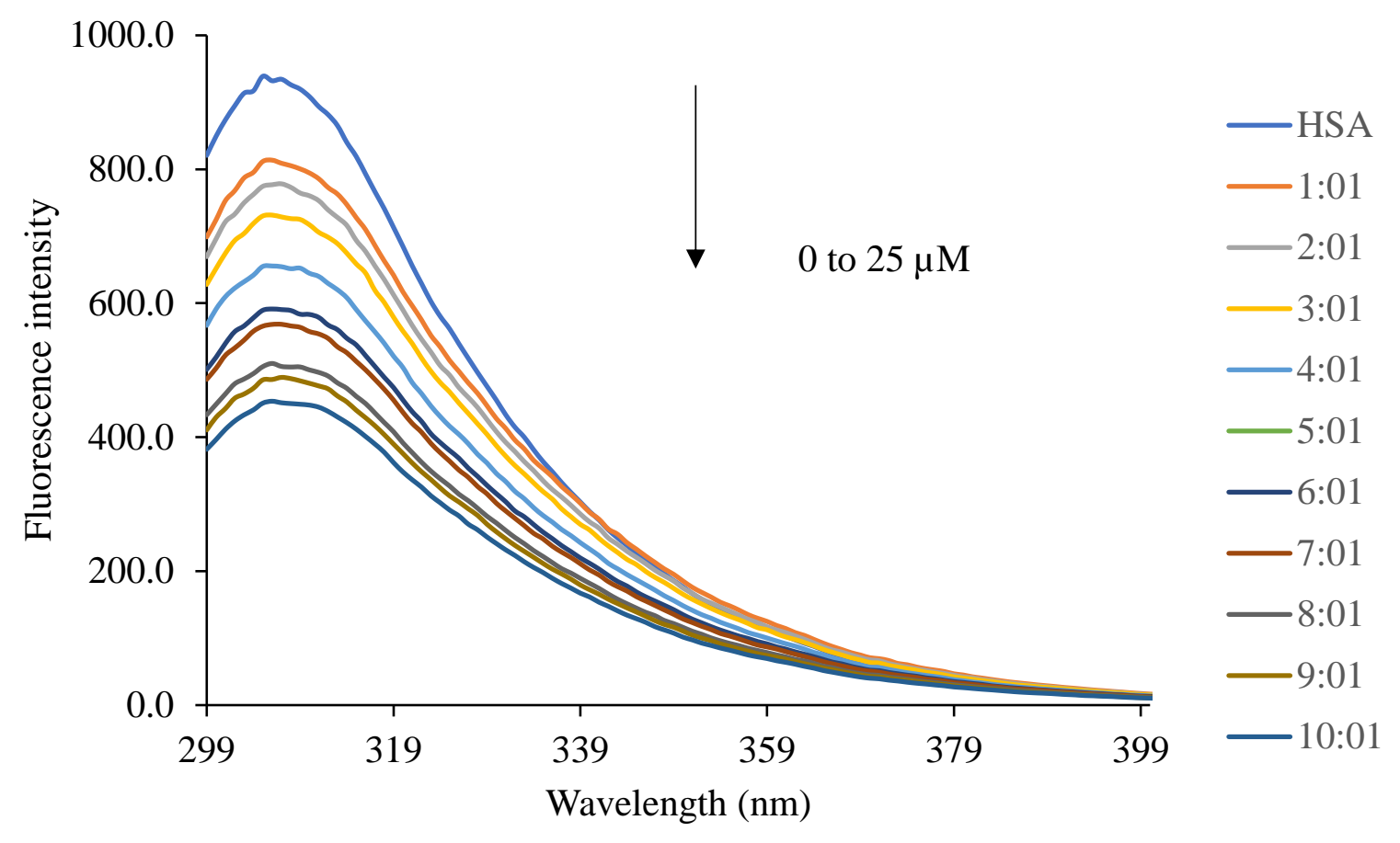

Figure C2. HSA fluorescence quenching by $\mathbf{C}_{4}$ at $37^{\circ} \mathrm{C}$ and $\mathrm{pH}$ of 7.4.

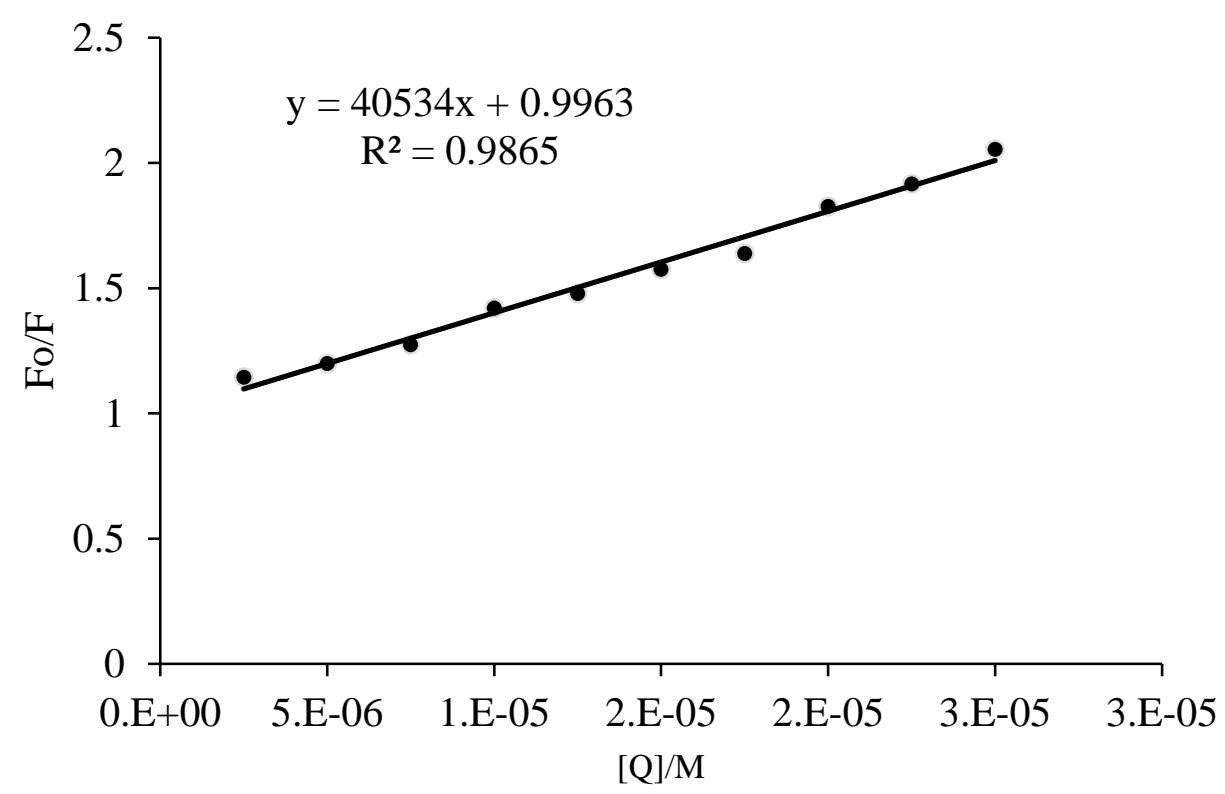

Figure C3. Stern-Volmer plot of $\mathbf{C} 4$. 


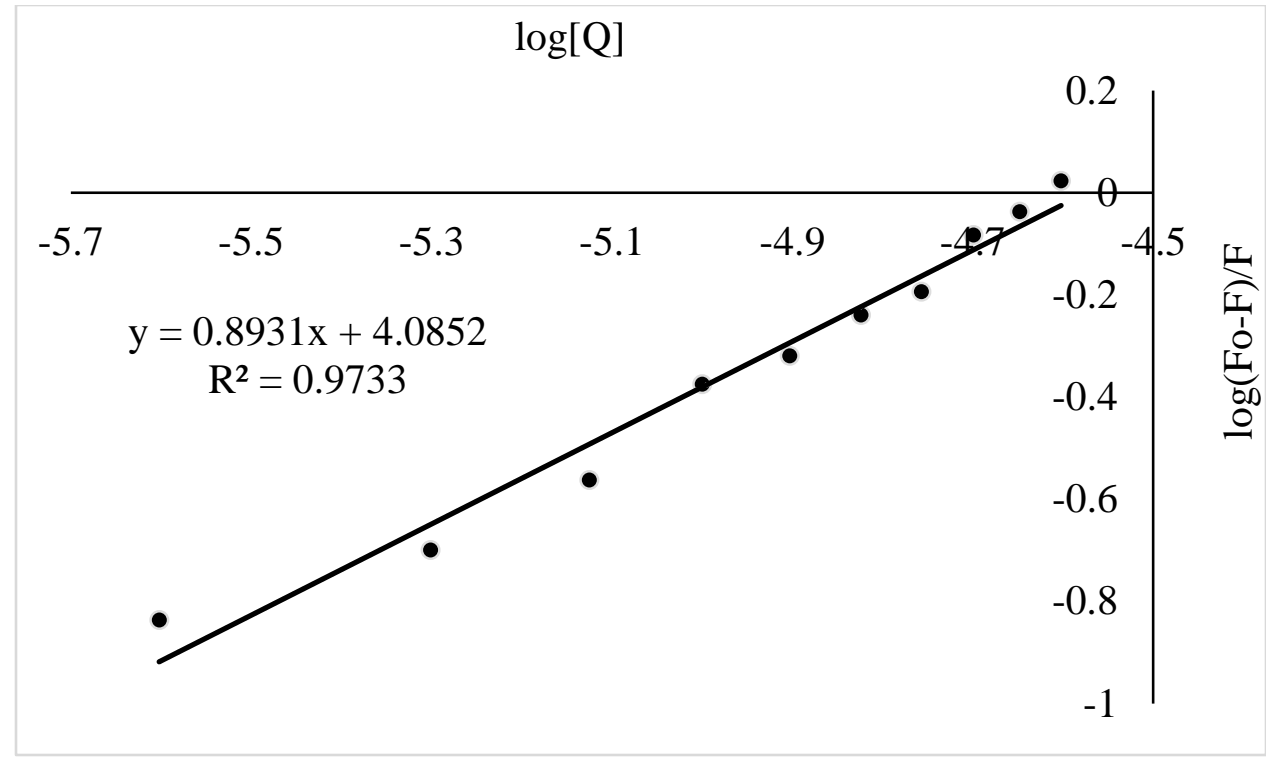

Figure C4. Modified Stern-Volmer plot $\mathbf{C 4}$.

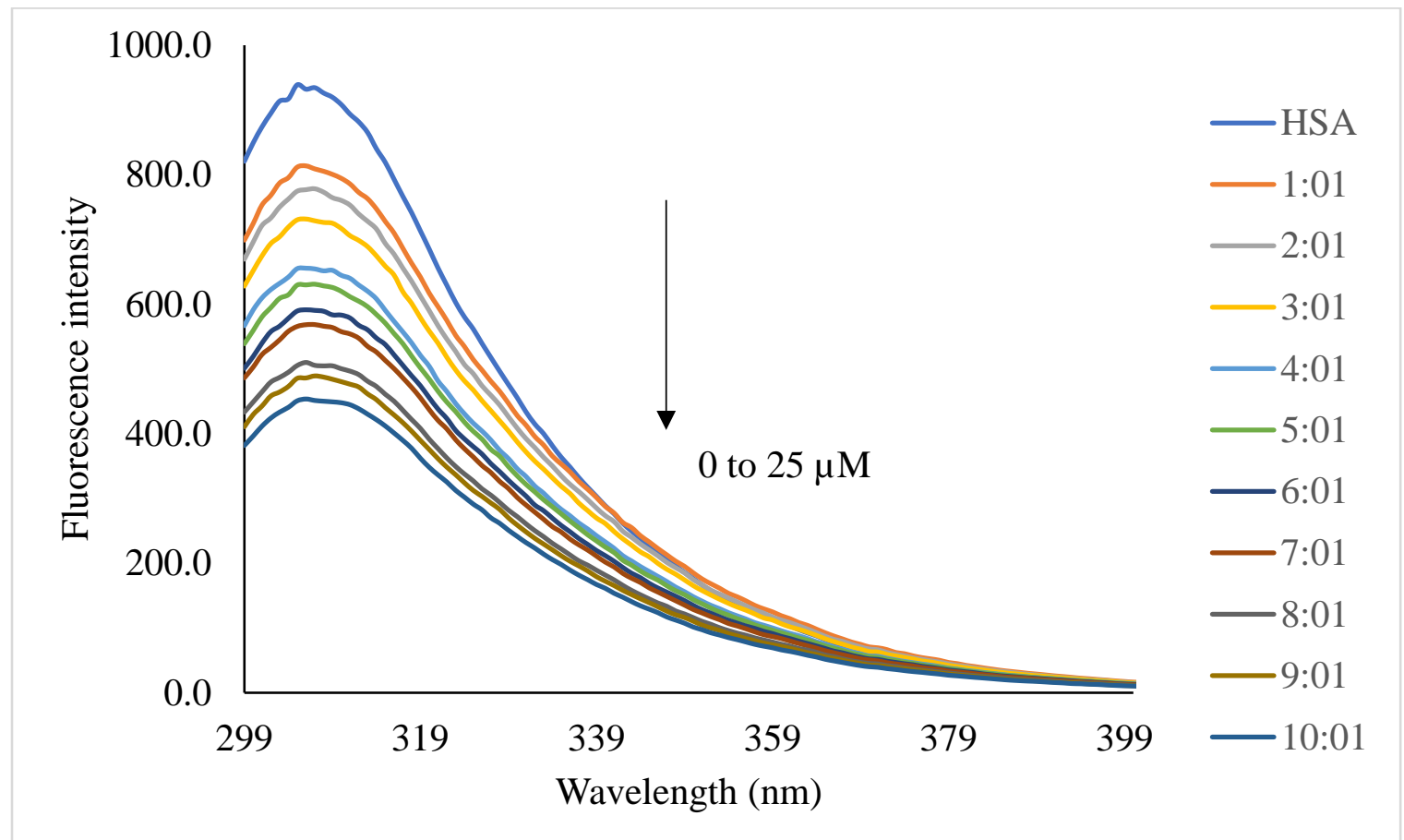

Figure C5. Fluorescence quenching of $\mathbf{C}_{6}$. 


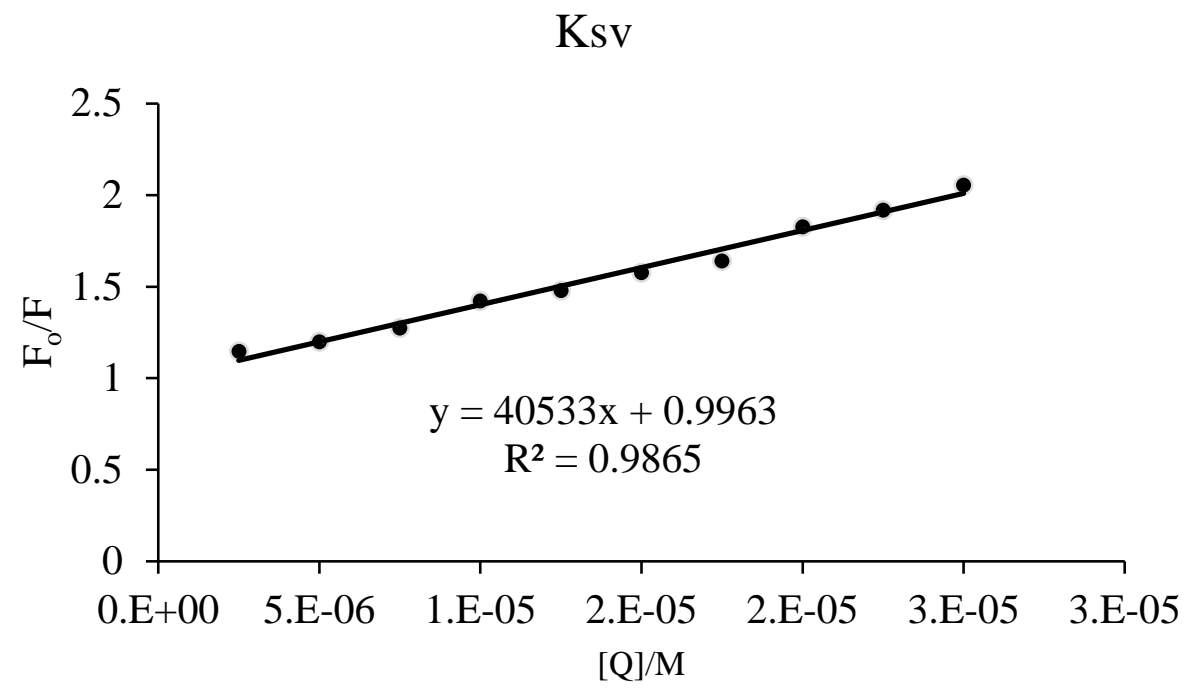

Figure C6. Stern-Volmer plot for $\mathbf{C}_{6}$.

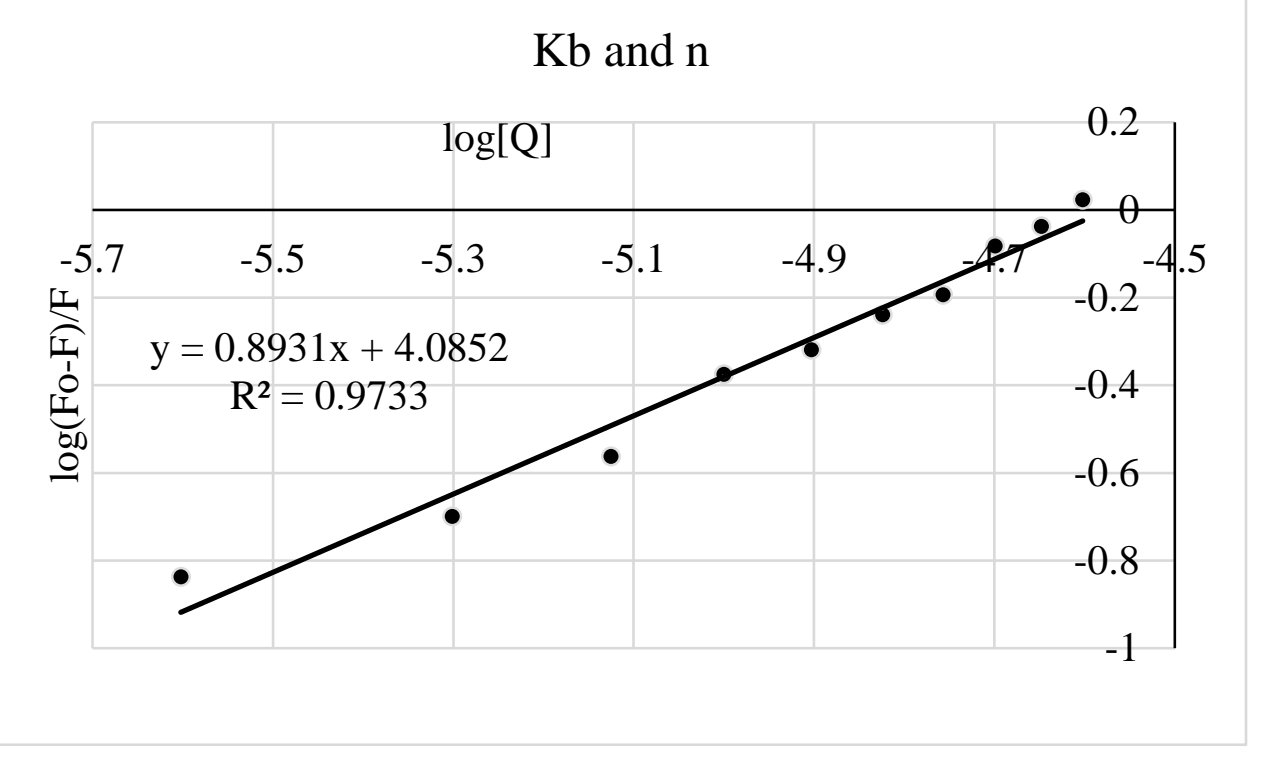

Figure C7. Modified Stern-Volmer plot for C6. $_{6}$ 